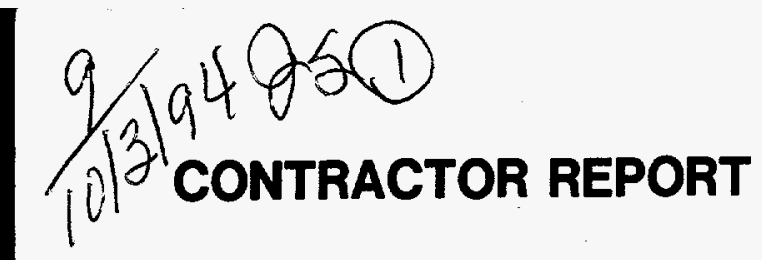

SAND93-7093

Unlimited Release

\title{
Biological Investigations of the Sandia National Laboratories Sol Se Mete Aerial Cable Facility
}

Dr. Robert M. Sullivan

4115 Allen Drive

Kingsville, TX 78363

\footnotetext{
Prepared by Sandia National Laboratories Albuquerque, New Mexico 87185 and Livermore, California 94550 for the United States Department of Energy under Contract DE-AC04-94AL85000
}

Printed October 1994

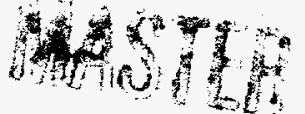


Issued by Sandia National Laboratories, operated for the United States Department of Energy by Sandia Corporation.

NOTICE: This report was prepared as an account of work sponsored by an agency of the United States Government. Neither the United States Government nor any agency thereof, nor any of their employees, nor any of their contractors, subcontractors, or their employees, makes any warranty, express or implied, or assumes any legal liability or responsibility for the accuracy, completeness, or usefulness of any information, apparatus, product, or process disclosed, or represents that its use would not infringe privately owned rights. Reference herein to any specific commercial product, process, or service by trade name, trademark, manufacturer, or otherwise, does not necessarily constitute or imply its endorsement, recommendation, or favoring by the United States Government, any agency thereof or any of their contractors or subcontractors. The views and opinions expressed herein do not necessarily state or reflect those of the United States Government, any agency thereof or any of their contractors.

Printed in the United States of America. This report has been reproduced directly from the best available copy.

Available to DOE and DOE contractors from

Office of Scientific and Technical Information

PO Box 62

Oak Ridge, TN 37831

Prices available from (615) 576-8401, FTS 626-8401

Available to the public from

National Technical Information Service

US Department of Commerce

5285 Port Royal Rd

Springfield, VA 22161

NTIS price codes

Printed copy: A06

Microfiche copy: A01 


\section{DISCLAIMER}

Portions of this document may be illegible in electronic image products. Images are produced from the best available original document. 


\title{
BIOLOGICAL INVESTIGATIONS OF THE SANDIA NATIONAL LABORATORIES SOL SE METE AERIAL CABLE FACILITY
}

\author{
Prepared by: \\ Dr. Robert M. Sullivan \\ 4115 Allen Dr. \\ Kingsville, TX 78363 \\ (512) 595-1261 \\ Prepared for \\ Department 2761 \\ Energetic and Environmental Testing Department \\ and \\ Department 7258 \\ Risk Management and NEPA Department \\ Task Leader: Theodore A. Wolff \\ Sandia Contract $\mathbf{4 8 1 2}$
}

\begin{tabular}{|l}
\hline ABSTRACT \\
This report provides results of a comprehensive biological field survey performed on the Sandia National \\
Laboratories (SNL) Aerial Cable Facility (ACF), at the east end of Kirtland Air Force Base (KAFB), Bernalilio \\
County, New Mexico. This survey was conducted during the period of late September through the end of October, \\
1991. ACF occupies a 440-acre tract of land withdrawn by the U.S. Forest Service (USFS) for use by KAFB, and \\
in turn placed under operational control of SNL by the Department of Energy (DOE). All land used by SNL for \\
ACF is part of a 15,851-acre tract of land withdrawn by the U.S. Forest Service. In addition, a number of \\
different organizations use the 15,851 -acre area. The project area used by SNL encompasses portions of \\
approximately six sections (3,840 acres) of U.S. Forest Service land located within the foothills of the west side \\
of the Manzano Mountains (East Mesa). The biological study area is used by the KAFB, the U.S. Department of \\
Interior, and SNL. This area includes: (1) Sol se Mete Spring and Canyon, (2) East Anchor Access Road, (3) East \\
Anchor Site, (4) Rocket Sled Track, (5) North Arena, (6) East Instrumentation Site and Access Road, (7) West \\
Anchor Access Road, (8) West Anchor Site, (9) South Arena, (10) Winch Sites, (11) West Instrumentation Sites, \\
(12) Explosive Assembly Building, (13) Control Building, (14) Lurance Canyon Road and vicinity. Although \\
portions of approximately 960 acres of withdrawn U.S. Forest Service land have been altered, only 700 acres have \\
been disturbed by activities associated with ACF; approximately 2,880 acres consist of natural habitat. Absence \\
of grazing by livestock and possibly native ungulates, and relative lack of human disturbance have allowed this \\
area to remain in a more natural vegetative state relative to the general condition of private range lands throughout \\
New Mexico, and relative to other grazing lands in central New Mexico. This report evaluates threatened and \\
endangered species found on ACF, as well as a comprehensive assessment of biological habitats.
\end{tabular}



List of Tables $\ldots \ldots \ldots \ldots \ldots \ldots \ldots \ldots \ldots \ldots \ldots$

List of Figures $\ldots \ldots \ldots \ldots \ldots \ldots \ldots \ldots \ldots \ldots \ldots \ldots \ldots \ldots \ldots \ldots$

List of Appendices $\ldots \ldots \ldots \ldots \ldots \ldots \ldots \ldots \ldots \ldots \ldots \ldots \ldots \ldots \ldots$

List of Acronyms and Abbreviations $\ldots \ldots \ldots \ldots \ldots \ldots$ vii

Executive Summary $\ldots \ldots \ldots \ldots \ldots \ldots \ldots \ldots$ ES-i

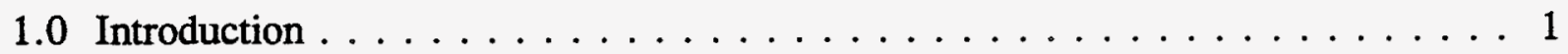

1.1 South Arena Test Scenarios . . . . . . . . . . . . . . . 6

1.1.1 Container Impact Testing $\ldots \ldots \ldots \ldots \ldots \ldots \ldots$

1.1.2 Air-to-Ground Weapons Testing $\ldots \ldots \ldots \ldots \ldots \ldots$

1.2 Specialized Support Operations $\ldots \ldots \ldots \ldots \ldots \ldots$

1.3 ACF Rocket Sled Track . . . . . . . . . . . . . . . . . . 10

1.4 North Arena Test Scenarios . . . . . . . . . . . . . . . . . . . . 10

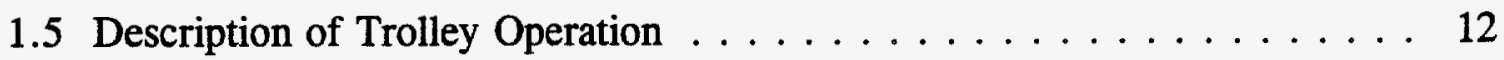

1.6 Test Frequency for Rockets and Explosives . . . . . . . . . . . . . . 14

1.7 Vehicle Usage $\ldots \ldots \ldots \ldots \ldots \ldots \ldots \ldots \ldots \ldots \ldots$

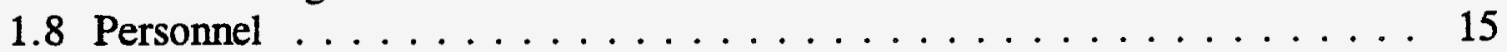

1.9 Utilities $\ldots \ldots \ldots \ldots \ldots \ldots \ldots \ldots \ldots \ldots \ldots \ldots$

2.0 Summary of Survey Methods $\ldots \ldots \ldots \ldots \ldots \ldots \ldots \ldots$

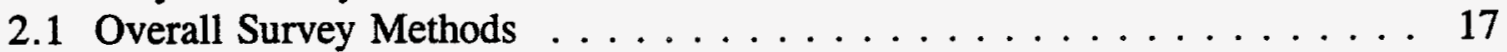

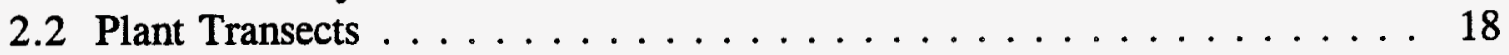

2.3 Bird Transects . . . . . . . . . . . . . . . . 20

2.4 Field Techniques for Small Mammal Trapping . . . . . . . . . . 22

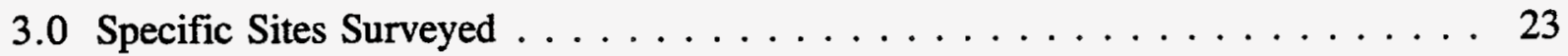

3.1 Sol se Mete Canyon . . . . . . . . . . . . . . . . . . 23

3.2 Junction Between East and West Forks of the Anchor Site Access Road . 23

3.3 East Anchor Access Road . . . . . . . . . . . . . . . . . . 25

3.4 West Anchor Access Road and West Anchor Site . . . . . . . . . 26

3.5 East Anchor Site . . . . . . . . . . . . . . . . . . . . . . . . . 27

3.6 East Slope of Sol se Mete Canyon, South Arena, Including Rocket Sled Track and Proposed New Cable Support Structure . . . . . . . . . . . 28

3.7 East Instrumentation Site and Access Road . . . . . . . . . . . . . . . . . 29

3.8 West Slope of Sol se Mete Canyon, North Arena, Including West Instrumentation Sites, Impact Area of 3-inch Gun, and Probable Location of New Cable Support Structure . . . . . . . . . . . . . 34

3.9 West Anchor Site . . . . . . . . . . . . . . . . 35 
3.10 Winch Site for the South Arena and Access Road . . . . . . . . . . . . 35

3.11 Explosive Assembly Building and Control Building . . . . . . . . . 36

3.12 Sol se Mete Spring Canyon . . . . . . . . . . . . . . 40

3.13 Lurance Canyon Road and Vicinity . . . . . . . . . . . . 42

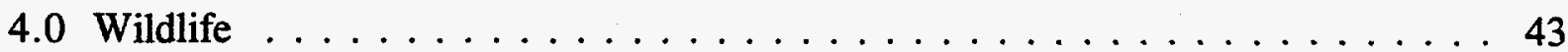

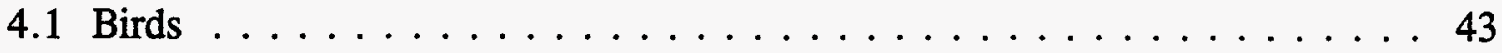

4.2 Mammals . . . . . . . . . . . . . . . . . 49

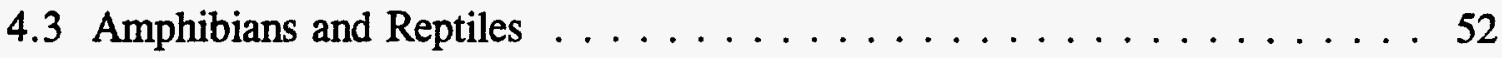

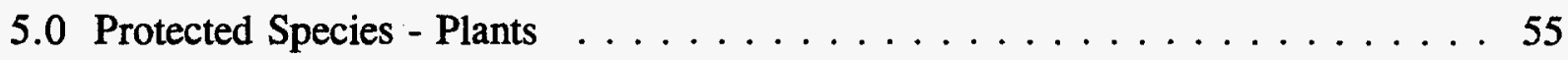

6.0 Protected Species - Animals . . . . . . . . . . . . . . . . 57

6.1 Cooper's Hawk . . . . . . . . . . . . . . . . . . 57

6.2 Sharp-shinned Hawk . . . . . . . . . . . . . . . . . 58

6.3 Red-tailed Hawk . . . . . . . . . . . . . . . . . 58

6.4 Northern Harrier . . . . . . . . . . . . . . . . . . . . 59

6.5 American Kestrel . . . . . . . . . . . . . . . . . . . . 60

6.6 Loggerhead Shrike . . . . . . . . . . . . . . . . . . . . 61

6.7 Gray Vireo . . . . . . . . . . . . . . . . . . 61

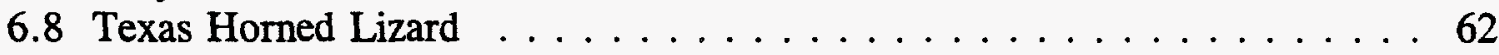

6.9 Short-horned Lizard . . . . . . . . . . . . . . . . . . . 63

6.10 Round-tailed Horned Lizard $\ldots \ldots \ldots \ldots$

7.0 Sensitive Habitat Areas . . . . . . . . . . . . . . . . 65

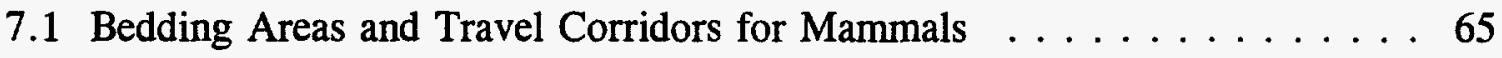

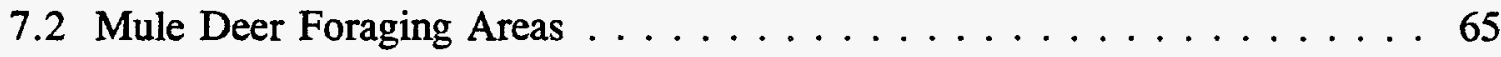

7.3 Raptor Use Areas . . . . . . . . . . . . . . . . . 66

7.4 Water Sources . . . . . . . . . . . . . . . . . . . . 67

7.4.1 Sol se Mete Spring . . . . . . . . . . . . . . 67

7.4 .2 Ephemeral Water Sources $\ldots \ldots \ldots \ldots \ldots \ldots . \ldots \ldots$

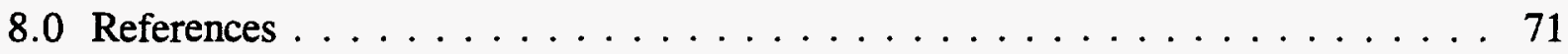

9.0 Distribution List $\ldots \ldots \ldots \ldots \ldots \ldots \ldots \ldots \ldots \ldots \ldots \ldots \ldots \ldots \ldots \ldots$ 


\section{LIST OF TABLES}

Table

Page

Table 1. Aerial Cable Facility areas included in the biological survey and acres surveyed . . . . . . . . . . . . . . . . . . . . . 19

Table 2. Results of plant surveys using the line-intercept method . . . . . . . . . 30

Table 3. Results of bird surveys in three different vegetation types . . . . . . . . . 44

\section{LIST OF FIGURES}

Figure

Page

Figure 1. Project Location near Albuquerque, NM . . . . . . . . . . . . . 3

Figure 2. Kirtland Air Force Base and Sandia National Laboratories Test Areas . . . 4

Figure 3. Aerial Photograph of SNL Aerial Cable Facility . . . . . . . . . . 5

Figure 4. View of South Arena from West Anchor Site . . . . . . . . . . . . . 7

Figure 5. Rocket-Assisted Pull-Down Technique for a Side Impact . . . . . . . . 10

Figure 6. North Arena, SNL Aerial Cable Facility . . . . . . . . . . . . . . 13

Figure 7. Project area in Sol se Mete Canyon and major topographic features . . . . 24

Figure 8. Percent frequency of occurrence of different vegetation groups sampled along various plant transects in the ACF project area along the east and west sides of Sol se Mete Canyon and the west slope of the Winch Site . 33

Figure 9. West facing slopes of ACF South Arena . . . . . . . . . . . . . 37

Figure 10. Sandia National Laboratories ACF Winch Site for the South Arena . . . 38

Figure 11. Explosive Assembly Building next to Lurance Canyon Road and the ACF Access Road along Sol se Mete Canyon-looking west . . . 39

Figure 12. View of canyon leading to Sol se Mete Spring where it branches east from the main access road south of the South Arena . . . . . . . . 41

Figure 13. Species composition and estimated densities of birds surveyed in habitat associated with grassland vegetation on the ACF . . . . . . 46

Figure 14. Species composition and estimated densities of birds surveyed in habitat associated with arroyo vegetation on the ACF . . . . . . . . 47

Figure 15. Species composition and estimated densities of birds surveyed in habitat associated with piñon-juniper-oak vegetation on the ACF . . . 48

Figure 16. Survey area for spotted owl. . . . . . . . . . . . . . I-3 


\section{LIST OF APPENDICES}

Appendix

Page

Appendix A. List of plant species observed in ACF biological study area. . . . . . A-1

Appendix B. List of plant species expected in the biological study area. . . . . . . . B-1

Appendix C. List of Threatened, Endangered, or Sensitive species of plants that potentially occur in ACF area . . . . . . . . . . . C-3

Appendix D. List of categories used to designate endangered and sensitive plant species in New Mexico . . . . . . . . . . . . . . D 1

Appendix E. List of animal species observed in the biological study area. . . . . . . E-1

Appendix F. List of animal species expected to be in the biological study area. . . . F-1

Appendix G. List of Threatened, Endangered, or Sensitive species of animals that potentially occur in ACF area . . . . . . . . . . . . . G-1

Appendix H. List of categories used to designate endangered and sensitive animal species in New Mexico . . . . . . . . . . . . . . H-1

Appendix I. Summary report on spotted owl (Roger Skaggs) . . . . . . . . . . I-1 


\section{LIST OF ACRONYMS AND ABBREVIATIONS}

$\begin{array}{ll}\text { ACF } & \text { Aerial Cable Facility } \\ \text { CCTC } & \text { Coyote Canyon Test Complex } \\ \text { CFR } & \text { Code of Federal Regulations } \\ \text { DOD } & \text { Department of Defense } \\ \text { DOE } & \text { Department of Energy } \\ \text { DOI } & \text { Department of Interior } \\ \text { DOT } & \text { Department of Transportation } \\ \text { EA } & \text { Environmental Assessment } \\ \text { eds. } & \text { editors } \\ \text { fps } & \text { feet per second } \\ \text { h } & \text { hours } \\ \text { HARC } & \text { Helicopter Accident Resistant Container } \\ \text { HVAR } & \text { High Velocity Aircraft Rocket } \\ \text { KAFB } & \text { Kirtland Air Force Base } \\ \text { kg } & \text { kilograms } \\ \text { km } & \text { kilometer } \\ \text { km }{ }^{2} & \text { square kilometer } \\ \text { m/s } & \text { meters per second } \\ \text { mph } & \text { miles per hour } \\ \text { NMDGF } & \text { New Mexico Department of Game and Fish } \\ \text { NMFD } & \text { New Mexico Forestry Division } \\ \text { NRC } & \text { Nuclear Regulatory Commission } \\ \text { PAT } & \text { Plutonium Air Transportable } \\ \text { pers. comm. } & \text { personal communication } \\ \text { pers. obs. } & \text { personal observation } \\ \text { SNL } & \text { Sandia National Laboratories } \\ \text { spp. } & \text { undetermined species } \\ \text { TA-III } & \text { Technical Area III } \\ \text { TRUPACT } & \text { Transuranic Waste Shipping Container } \\ \text { TSC-V } & \text { Transportation Safety Container-Variant } \\ \text { USAF } & \text { U.S. Air Force } \\ \text { USC } & \text { United States Code } \\ \text { USFS } & \text { U.S. Forest Service } \\ \text { USFWS } & \text { U.S. Fish and Wildlife Service } \\ \text { USN } & \text { U.S. Navy } \\ \text { var. } & \text { variety } \\ & \end{array}$


This page intentionally left blank. 


\section{EXECUTIVE SUMMARY}

This report provides results of a comprehensive biological field survey performed on the Sandia National Laboratories (SNL) Sol se Mete Aerial Cable Facility (ACF), at the east end of Kirtland Air Force Base (KAFB), Bernalillo County, New Mexico. This survey was conducted during late September through late October, 1991. By land use agreements with the U.S. Air Force (USAF), the U.S. Department of Energy (DOE) SNL is authorized to use a 440-acre tract of land withdrawn by the U.S. Forest Service (USFS) for use by ACF, and in turn placed under operational control of SNL by the DOE. SNL uses roadways and other land adjoining the dedicated 440-acre tract. All land used by SNL for ACF is part of a 15,851-acre tract of land withdrawn by the USFS. In addition, a number of different organizations use the 15,851-acre area [e.g., KAFB, other SNL users, different departments within the DOE, and the Department of Transportation (DOT)].

Biological assessments were made for all areas potentially affected by the ACF. This larger area encompasses portions of approximately six sections (3,840 acres) of USFS land located within the foothills of the west side of the Manzano Mountains.

The biological study area is used by the KAFB, the U.S. Department of Interior (DOI), and SNL. Within the biological study area are located a number of locations and facilities used by the ACF, including: (1) Sol se Mete Spring and Canyon, (2) East Anchor Access Road, (3) East Anchor Site, (4) Rocket Sled Track, (5) North Arena, (6) East Instrumentation Site and Access Road, (7) West Anchor Access Road, (8) West Anchor Site, (9) South Arena, (10) Winch Sites, (11) West Instrumentation Sites, (12) Explosive Assembly Building, (13) Control Building, (14) Lurance Canyon Road and vicinity.

Of the total 3,840 acres surveyed within the biological study area, approximately 960 acres of withdrawn USFS land have been altered; of these 960 acres, only about 700 acres have been disturbed by activities associated with ACF. Thus, approximately 2,880 acres consist of natural habitat. Absence of grazing by livestock and relative lack of human disturbance 
have allowed this area to remain in a more natural vegetative state relative to the general condition of private range lands throughout New Mexico, and relative to other grazing lands in central New Mexico. This report evaluates threatened and endangered species found in the ACF, as well as a comprehensive assessment of biological habitats. Included are analyses of potential impacts and mitigative measures designed to reduce or eliminate potential impacts.

Of seven threatened, endangered, or sensitive species of plants potentially present in the ACF biological study area, only one species was documented within ACF project limits. This was the daggerthorn cholla (Opuntia clavata), which occurs in Chihuahuan desert scrub habitat surrounding ACF and adjacent access roads. It is locally abundant in grassland habitat on ACF. During the survey period in 1991, O. clavata was classified as a State of New Mexico Priority 1 species with no Federal status. However, the New Mexico State Forestry Division has placed no special restrictions on potential destruction of individual plants of this species; and $O$. clavata has been dropped from the Inventory of Rare and Endangered Plants of New Mexico. Therefore, continued use of ACF facilities does not appear to pose a significant threat to any endangered plant species or their habitats. However, several Federal or State of New Mexico endangered species of plants occur in grassland habitat near the ACF biological study area (Sullivan and Knight, SAND93-7089, 1994); therefore, these species potentially may occur within the ACF biological study area:

- Grama grass cactus (Toumeya papyracantha) is a Federal Category 2 Candidate as well as a State of New Mexico Endangered (R-E-D Code 1-2-2) species which is abundant on the Coyote Canyon Test Complex (CCTC) (see Appendix D for definition of codes)

- Santa Fe milkvetch (Astragalus feensis) currently is a State of New Mexico Sensitive (R-E-D Code 1-1-3), with no Federal status, found infrequently on the CCTC area 
- Wright's fishhook cactus (Mammillaria wrightii var. wrightii) currently is a State of New Mexico Endangered (R-E-D Code 1-2-2), with no Federal status, found in the vicinity of the Live Firing Range located to the west of ACF.

Of 25 threatened, endangered, or sensitive species of animals potentially occurring within the area, 11 were documented within ACF:

- Sharp-shinned hawk (Accipiter stricture) (no Federal status; State of New Mexico protected)-canyon leading to Sol se Mete Spring

- Cooper's hawk (Accipiter cooperi) (no Federal status; State of New Mexico protected)-canyon leading to Sol se Mete Spring

- Golden eagle (Aquila chrysaetos) (full Federal protection and State of New Mexico protected)-grassland habitat in Lurance Canyon, 33 meters (100 feet) north of Lurance Canyon Road (NOTE: the home range of this species is probably within the ACF even though it was observed only along the northern edge of the biological study area)

- Red-tailed hawk (Buteo jamaicensis) (no Federal status; State of New Mexico protected)-grassland and piñon pine-juniper ecotone adjacent to Lurance Canyon Road

- Northern harrier or marsh hawk (Circus cyaneous) (no Federal status; State of New Mexico protected)-ecotone between grassland and piñon pine-juniper vegetation along Lurance Canyon Road

- American kestrel (Falco sparverius) (no Federal status; State of New Mexico protected)-ecotone between grassland and piñon pine-juniper habitat along Lurance Canyon Road

- Loggerhead shrike (Lanius ludovicianus) (Federal Category 2 Candidate; no State of New Mexico status)-along Lurance Canyon Road, particularly tall road-side vegetation and wire fences that overlook grassland habitat 
- Gray vireo (Vireo vicinior) (no Federal status; State of New Mexico Endangered Group 2)-piñon pine-juniper woodland near the lower drinker tank at the entrance of the canyon leading to Sol se Mete Spring

- Texas horned lizard (Phrynosoma cornutum) (Federal Category 2 Candidate; State of New Mexico protected) - grassland-juniper habitat near intersection of Lurance and Sol se Mete Canyons

- Short-horned lizard (Phrynosoma douglassi) (no Federal status; State of New Mexico protected)-grassland-juniper habitat along Lurance Canyon

- Round-tailed horned lizard (Phrynosoma modestum) (no Federal status; State of New Mexico protected)-grassland and piñon pine-juniper vegetation adjacent to Lurance Canyon.

Canyons, drainages, and other open areas located at the head of Lurance and Madera Canyons potentially could provide nest sites suitable for use by golden eagles and other large raptors. Red-tailed hawks and American kestrels occur frequently in grassland-juniper habitat, or the ecotone between grassland and piñon pine-juniper woodland along Sol se Mete Canyon, and between this canyon and the Winch Site. Large junipers within the grassland vegetation and large piñon pine at the woodland edge provide observation and perching sites for raptors that prey on the abundance of small mammals associated with the grasslandjuniper and shrubby vegetation of the arroyos. Sightings of Cooper's and sharp-shinned hawks in arroyo vegetation and piñon pine-juniper woodland in Sol se Mete Spring Canyon, and in upper regions of the East Anchor Access Road, indicate that these woodlands provide cover, nesting, and perching sites for local species of raptors. In addition, a perennial source of free water and large prey-base of perching birds found in Sol se Mete Canyon provide ideal habitat for small bird-eating hawks. Coyote Springs, Burn Site Spring, and Sol se Mete Spring provide the only perennial sources of free water found near or within the biological study area. These springs provide the only sources of free water to local species of wildlife.

Mule deer are frequently observed (pers. obs.) throughout the ACF, and the heaviest concentrations of mule deer and their sign occur along the ecotone between grassland-juniper 
and woodland habitat of Sol se Mete Canyon north of the North Arena, and in the canyon leading to Sol se Mete Spring. Mule deer sign also was evident along the grassland-juniper and piñon pine-juniper ecotone extending from the Winch Site to the western edge of the Explosive Assembly Area and parking lot. Locations of foraging areas were highly correlated with distribution of bedding areas and travel corridors. Foraging areas were consistently associated with the ecotone between grassland, piñon pine-juniper woodland, and shrubby arroyo vegetation, which provided the largest diversity of vegetation for browsers and other herbivorous species, and provide low-elevation winter range (e.g., source of food and habitat) for mule deer.

Within ACF, a number of potentially sensitive wildlife habitats were identified, and impacts to vegetation and wildlife species were evaluated. Survey results indicate that areas within ACF which historically have sustained the largest amount of habitat disturbance also have had the fewest native plants and animal species; these disturbed areas were in a poorer condition than less disturbed habitat. No threatened, endangered, or sensitive species of plants were found in the ACF area. Concerning threatened, endangered, and protected animal species, four Federally listed species were noted (the golden eagle, which is fully Federally protected; and the loggerhead shrike, the gray vireo, and the Texas horned lizard; all of which are Federal Category 2 Candidates). As noted earlier, the survey located ten species protected under New Mexico statutes. 
This page intentionally left blank. 


\subsection{INTRODUCTION}

Sandia National Laboratories (SNL) operates the Sol se Mete Aerial Cable Facility (ACF) at Kirtland Air Force Base (KAFB), New Mexico, for the Department of Energy (DOE). The ACF is located on the eastern portion of KAFB. It is situated within Cibola National Forest on land withdrawn under a 1967 agreement between the U.S. Air Force (USAF) and the U.S. Forest Service (USFS). Subsequently, a portion of the land was placed under DOE control for use by the ACF under a supplemental agreement between DOE and KAFB. The ACF is located within an area known as the Coyote Test Field.

A detailed Environmental Assessment (EA), including a summary of ACF program and testing activities, will be published by the DOE. Based on the biological assessment contained in this Contractor SAND Report, the EA is evaluating the following environmental categories: human and occupational health and safety, air quality, land use, biological resources, endangered species, cultural resources, noise, economic conditions, energy resources, hazardous and toxic material, explosives storage and handling, and sanitary waste discharge systems. Additive and cumulative effects also are being evaluated. The methodological approach consists of identification of potential environmental issues, determination of possible significance, and providing recommendations to reduce or eliminate potential environmental impacts.

The ACF consists of a series of cables are suspended across Sol se Mete Canyon and adjacent facilities to support tests and evaluations done using the cables. The cable system is used to suspend test articles for ground impact tests under controlled acceleration conditions. Gravitational acceleration is used to achieve test article impact velocities of up to 46 meters per second [150 feet per second (fps)]. Impact velocities up to 244 meters per second (800 fps) can be achieved through a rocket sled pull-down towing technique. The cable also is used as a tramway for moving trolleys that support targets used for testing a variety of passive and active electronic, optical tracking, and acquisition devices. 
Presently, one steel cable and one Kevlar cable, each approximately 1,524 meters (5,000 feet) long, are used in the South Test Arena, and two other steel cables also 1,524 meters (5,000 feet) long are used in the North Arena. The two test arenas are located approximately 305 meters (1,000 feet) apart on the canyon floor.

Figures 1 and 2 define the geographical location of the ACF. Figure 3 is an aerial photograph of the ACF, labeled to show significant structures. 


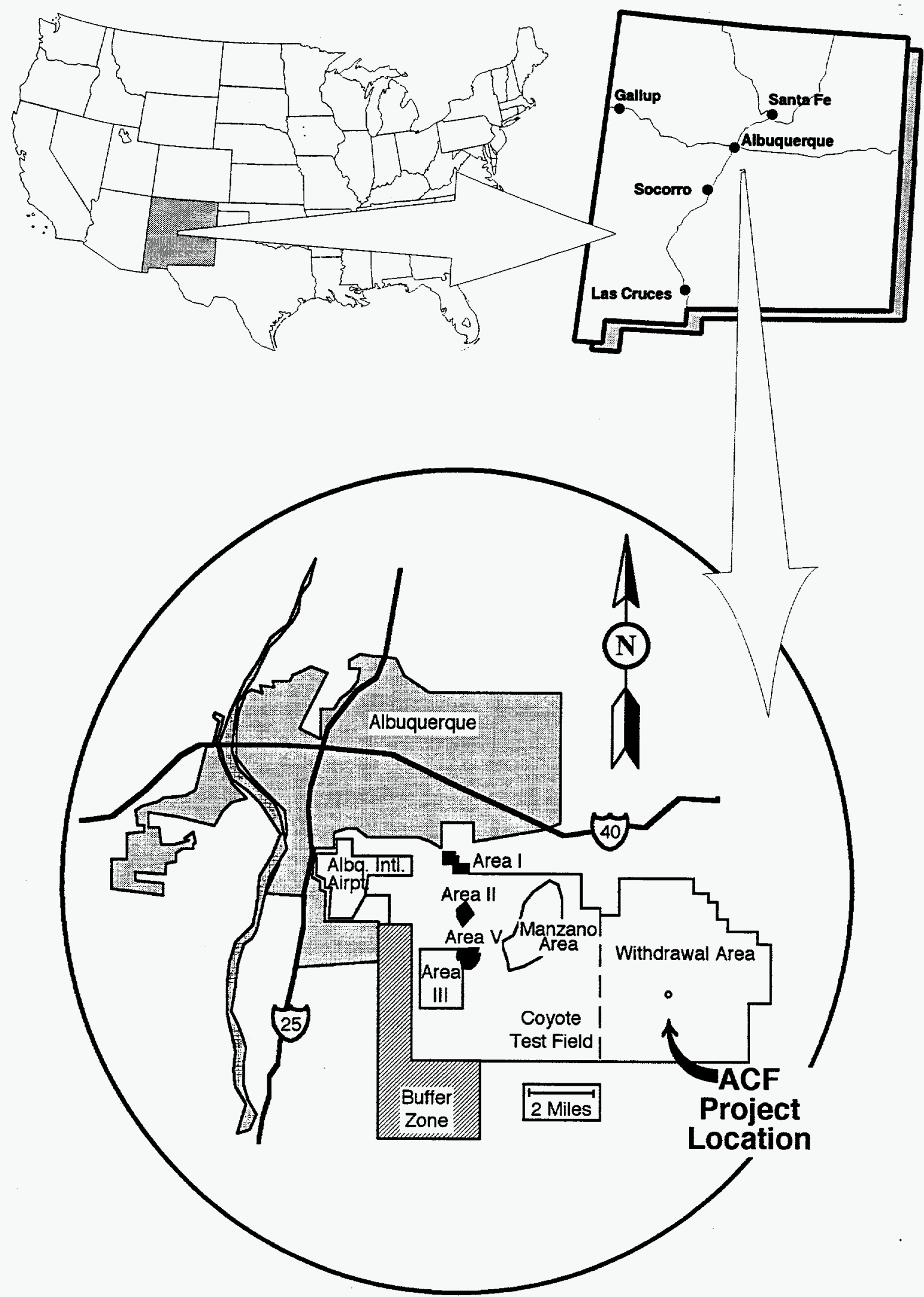

Figure 1. Project Location near Albuquerque, NM 


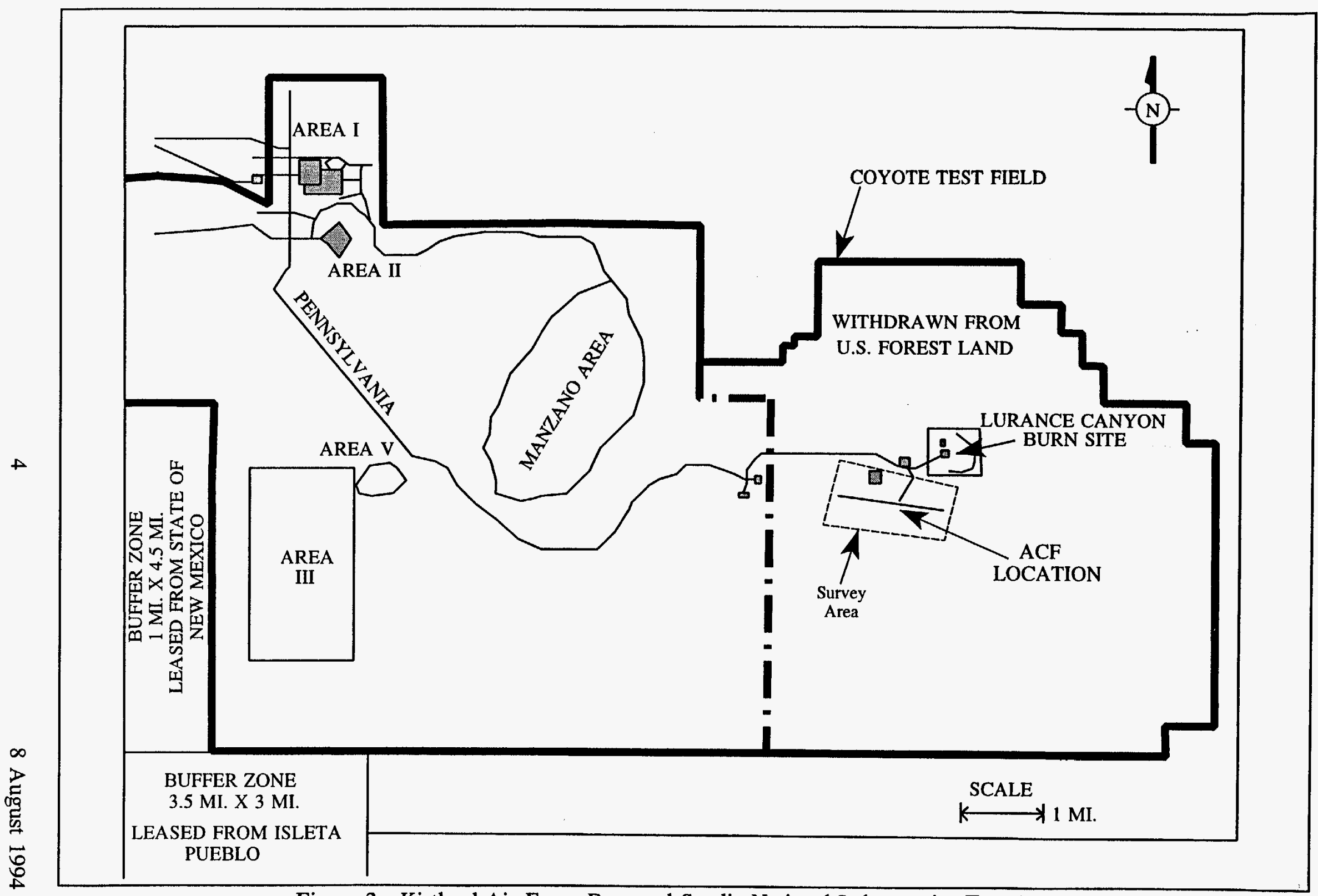

Figure 2. Kirtland Air Force Base and Sandia National Laboratories Test Areas 


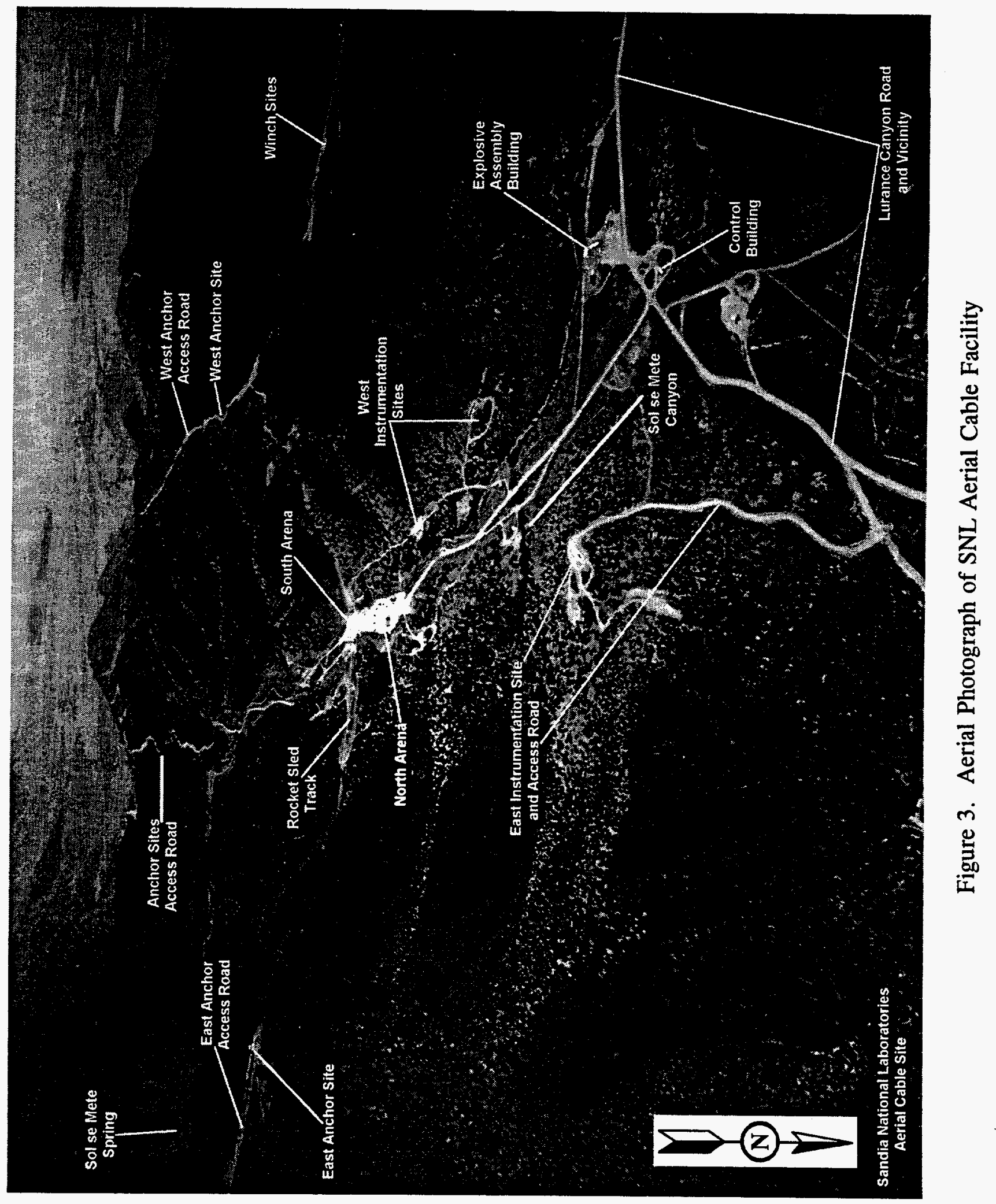


The ACF fulfills multiple purposes in support of DOE research and development activities listed below. These purposes are discussed in greater detail in this section. ACF test activities include the following:

- Precision impact certification testing of nuclear material shipping containers in accordance with Title 10 Part 71 of the Code of Federal Regulations (10 CFR Part 71).

- Precision testing of full-scale, air-delivered weapons tests.

- Precision testing of airborne sensors and sensor-fuzed weapons systems released from a stable aerial platform located above ground targets.

- Precision testing of ground-based sensors and target-acquisition devices directed against simulated aircraft and aircraft targets traversing the ACF cableways.

\subsection{SOUTH ARENA TEST SCENARIOS}

The South Arena is the primary test area for impact tests and tests requiring trolley travel along the overhead cables. Presently, one heavy steel cable and one Kevlar cable are used, in conjunction with the ACF Rocket Sled Track, for nuclear material shipping container impact certification testing and air-to-ground weapon testing. For purposes of impact tests, the South Arena also contains a unique "unyielding target" constructed beneath the ACF cableway with two million pounds of reinforced concrete below ground level and capped with steel armor plate at ground level.

The ACF South Arena is shown in Figure 4. 


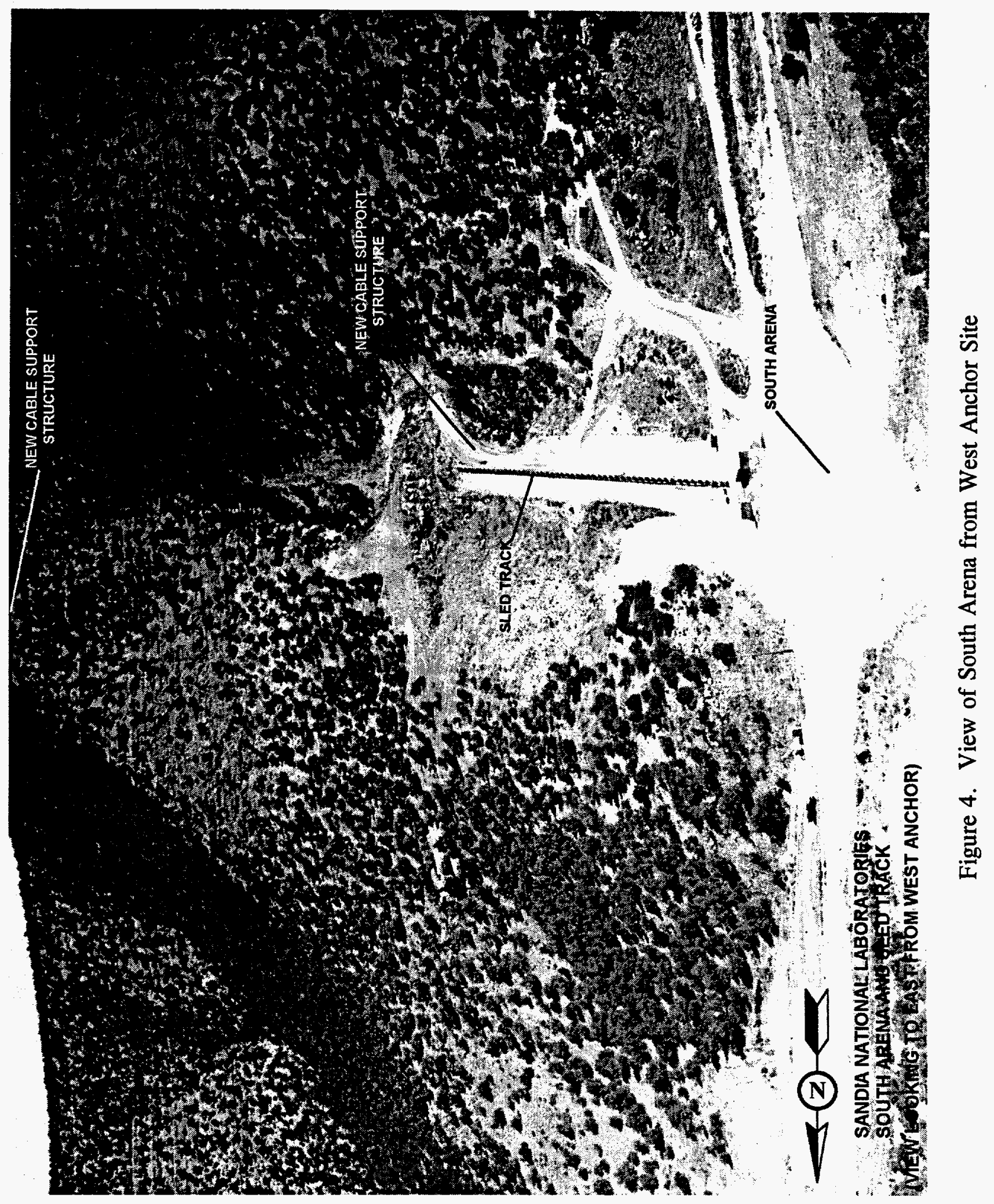




\subsubsection{Container Impact Testing}

In accordance with Title 10 Part 71 of the Code of Federal Regulations (10 CFR Part 71), shipping containers used to transport nuclear materials must be designed to minimize the likelihood of releasing radioactive material in transportation accidents. The ACF is used to demonstrate compliance with impact-related container test provisions of this Federal regulation. The regulations require that the evaluation and certification of containers for transporting radioactive material be completed by testing the containers under impact, puncture, penetration, thermal exposure, water spray, and immersion conditions.

The ACF is capable of testing a range of container sizes from small containers weighing 952.5 kilograms $(\mathrm{kg})$ (2,100 pounds), and impacting at velocities of up to 243.8 meters per second $(\mathrm{m} / \mathrm{s})$ or 800 feet per second (fps), to large containers weighing up to $90,718.5 \mathrm{~kg}$ (100 tons) that are lifted a few meters above the ground and dropped to achieve impact velocities of only a few meters per second. Current Department of Transportation (DOT) and Nuclear Regulatory Commission (NRC) container impact resistance specifications are largely based upon work that SNL has performed at the ACF.

Over the past 20 years, more than 100 container impact test series have used the ACF testing facilities in the ACF South Arena (Hohnstreiter, et al., 1991). Included in these test programs were tests of the Plutonium Air Transportable (PAT) container, the TRUPACT II container, the Big Rock Point container, the Helicopter Accident Resistant Container (HARC), and Three Mile Island Transportation Systems. The most recent container test programs have been for the certification of the Transportation Safety Container-Variant (TSC-V) and the H1501A HARC. Test articles used in the impact studies conducted in the South Arena are actual shipping containers with mock weapon components.

Since 1987, over 120 tests have been conducted using test articles designed to contain nuclear materials, and over 20 of these test units contained depleted uranium. There have been no recorded incidents of mock weapon components being fractured as a result of test 
activities, and all radioactive materials have been recovered following each test (Bickel, pers. comm., 1993). Therefore, impact tests of transportation containers have successfully confirmed the capabilities of these containers to protect ordnance from damage. Because there is no information indicating any release of radioactive materials from these tests, there is very little likelihood of contamination of the test facility as a result of these tests.

\subsubsection{Air-to-Ground Weapons Testing}

The ACF, by engineering simulation, can match the full range of subsonic aircraft speeds for delivering full-scale, air-to-ground, inert weapons. Inert weapons are suspended from the aerial cable and are either dropped free-fall, or are "pulled down" by the rocket sled, to simulate the appropriate delivery velocity of each weapon. Testing and evaluation using the ACF provide significant advantages over aircraft delivery methods during the early stages of weapon development, when accuracy of the weapon flight profile and impact characteristics are the critical parameters in evaluating weapon design. Additionally, release equipment and weapon separation characteristics can be tested at the ACF prior to entering that portion of the weapon test cycle involving compatibility with the delivery aircraft. At this stage in the weapon development cycle, use of the ACF provides for higher probability of acquiring valid test data using test procedures that are less expensive than attempting to test delivery methods using actual aircraft operations.

\subsection{SPECIALIZED SUPPORT OPERATIONS}

The South Arena also is used for highly specialized testing of the target and scoring system of U.S. Navy (USN) armaments. The target (to include projectile missile sensors and scoring protocol) must be certified annually. The target is supported from the aerial cable and up to 100 rounds of $20-\mathrm{mm}$ cannon fire, 120 rounds of 3-inch naval gun fire, or other weapons are fired at the target. Sophisticated electronics inside the target are used to sense the miss-distance for the passing rounds. From known trajectories for the projectiles, the test allows calculation of the accuracy of target sensing and electronic equipment. 


\subsection{ACF ROCKET SLED TRACK}

Based on operational experience, up to 35 tests per year involve use of a rail-mounted sled accelerated by rocket motors to attain high velocities. The rocket sled is propelled by a combination of Zuni and High Velocity Aircraft Rocket (HVAR) rocket motors typically contain about $63.5 \mathrm{~kg}$ (140 pounds) of propellant. The primary use of this rocket sled track is to "pull-down" test articles from the aerial cable at predetermined velocities that are greater than can be achieved by gravity acceleration. This capability has been used for more than 20 years in tests of mock nuclear ordnance and shipping containers for impact resistance and performance of weapon systems.

The "pull-down" testing sequence, as shown in Figure 5, is as follows: A wire rope towing system is used to attach the rocket sled to the test article that is suspended from the aerial cable. Towing lines run horizontally behind the sled for about 61 meters (200 feet), where they turn vertically around high-speed wire rope pulleys. The towing lines continue vertically from 183 to 305 meters $(600-1,000$ feet), where they attach to the test article that is supported from the aerial cable. Zuni and HVAR motors are used to accelerate the sled and the pull-down apparatus. The test article is released from the cable as rockets are ignited, and the test article is pulled downward at the same rate the sled moves along the rocket sled track. The test article is accelerated at up to 40 times the acceleration of gravity along its downward flight path reaching speeds up to $268.2 \mathrm{~m} / \mathrm{s}$ (880 fps) in less than 1 second, and the test article impacts precisely on target.

In 1992, as a maintenance replacement action, the original rocket sled track was replaced by a new track with identical dimensions.

\subsection{NORTH ARENA TEST SCENARIOS}

The ACF North Arena was constructed in 1985. It comprises a separate steel cable system extending from the fixed East Anchor to the West Anchor, and extending down to a winch 


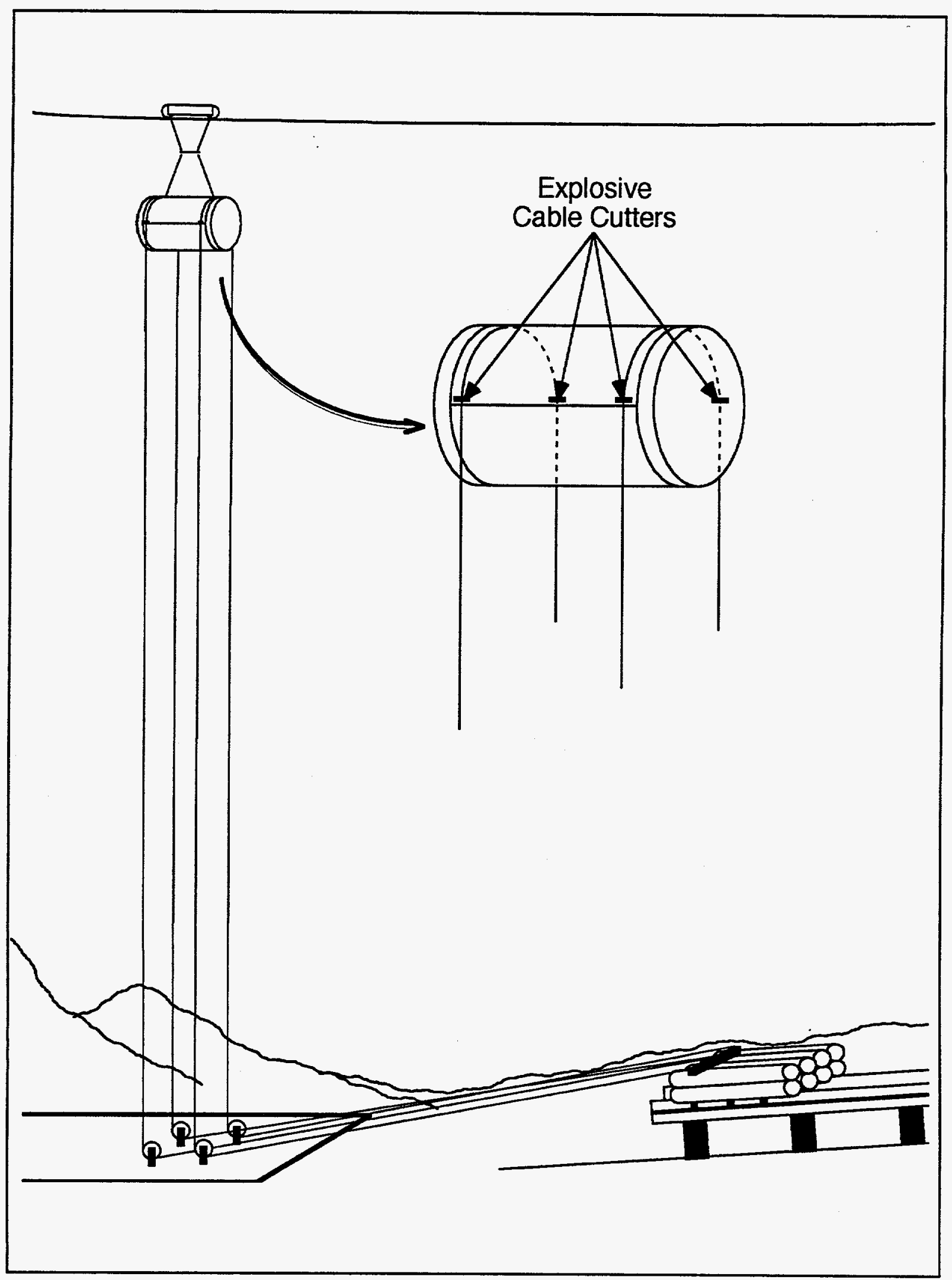

Figure 5. Rocket-Assisted Pull-Down Technique for a Side Impact 
site that is separated from the winch sites used for the South Arena cable systems. The North Arena cable is steel, with a separate camera cable. One of the cable systems uses anchorages nearer the ground impact area.

This arena is used for engineering simulations involving test articles dropped from the cable onto a target array positioned underneath the cable. In previous tests, up to 16 separate test articles have been dropped against a simulated target array of up to 16 target military tanks (Figure 6). In normal tests, the test article packages can range from sensor-only packages to test target acquisition capabilities to packages using explosive charge devices that allow determination of probable impact values. The target array can be a variety of sensor packages or a variety of simulated or actual tactical vehicles.

\subsection{DESCRIPTION OF TROLLEY OPERATION}

A maximum of 50 trolley operations are performed per year at the ACF. Each unboosted trolley operation can consist of as many as 10 individual traversals of the cable. The ACF acts as a tramway for trolleys and/or targets that traverse the cable rolling on sheaves. The trolleys are able to achieve velocities in the range of $26 \mathrm{~m} / \mathrm{s}$ ( $85 \mathrm{fps}$ ) if gravity-accelerated from the east end of the ACF. Higher velocities can be reached by rocket boosting the trolleys. Surplus Zuni and HVAR rocket motors are used to accelerate the trolley. Velocities up to $245 \mathrm{~m} / \mathrm{s}$ (760 fps) are anticipated for an estimated ten yearly tests.

The trolley and target may weigh up to $3,175 \mathrm{~kg}$ (7,000 pounds). Trolleys are braked by a combination of devices that could include drogue parachutes, restraining devices similar to those used on aircraft carriers, or similar devices capable of attaining a soft impact. Heavier trolleys traveling at higher velocities may require retro-rockets to reduce the trolley kinetic energy to a level at which other restraining and braking mechanisms are effective. 


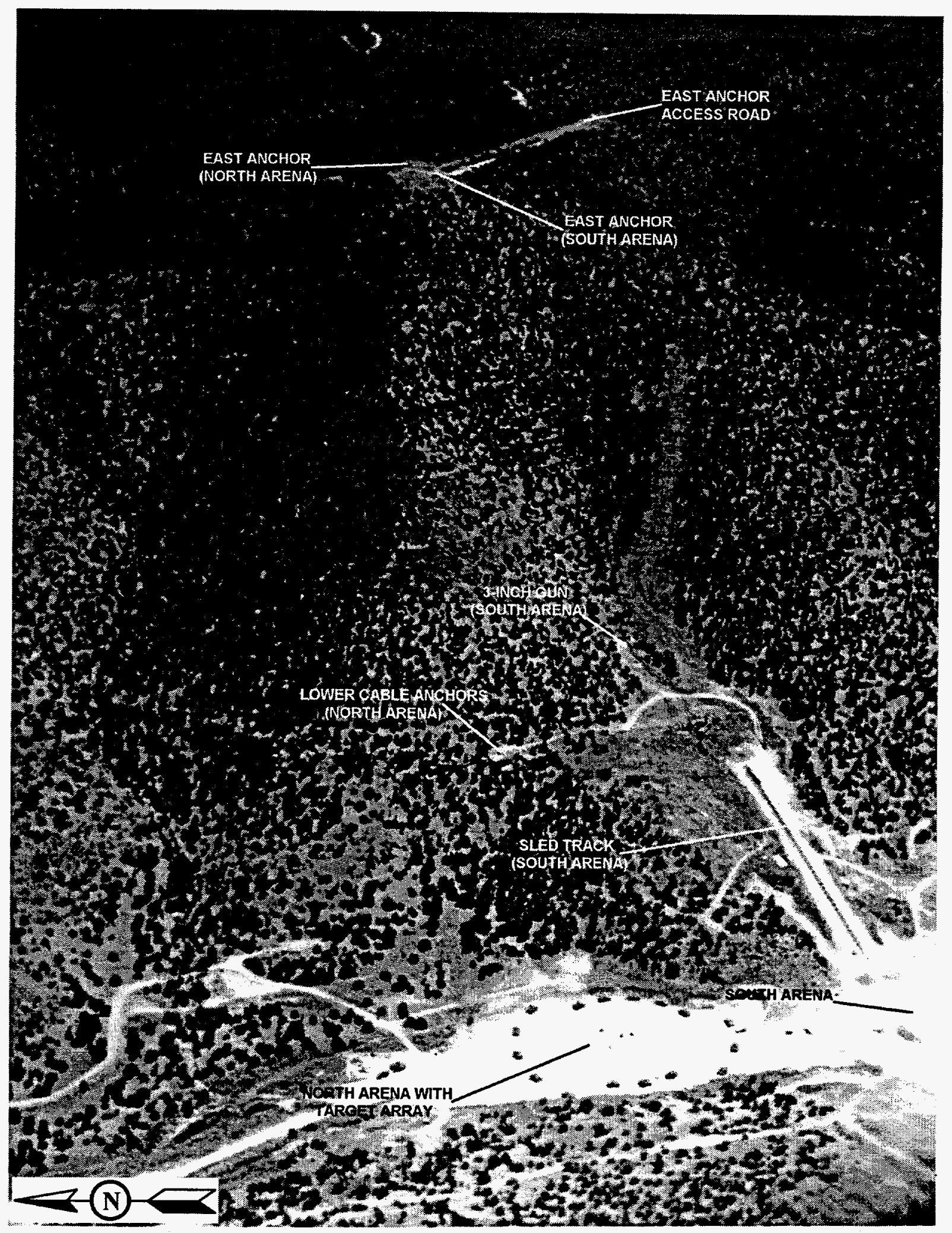

Figure 6. North Arena, SNL Aerial Cable Facility 


\subsection{TEST FREQUENCY FOR ROCKETS AND EXPLOSIVES}

The ACF is used for an average of 220 tests per year. Approximately 75 of these tests represent relatively environmentally benign activities such as testing operations involving passive electro-optical sensors or related activity. Tests in the potentially environmentally intrusive category include the following:

\begin{tabular}{lc}
\hline & $\begin{array}{c}\text { Assumed } \\
\text { Maximum Annual } \\
\text { Test Frequency }\end{array}$ \\
Description & 35 \\
\hline Rocket-boosted pull-down tests (typically, 5 rockets per test) & 10 \\
Rocket-assisted aerial target/trolley (typically, 5 rockets per test) & 100 \\
Detonation of up to $1.4-1.8 \mathrm{~kg}$ (3 - 4 pounds) of high explosives & \\
Detonation of 54.4 - 453.6 kg (120 - 1,000 pounds) of high & 1 \\
$\quad$ explosives & 1 \\
Weapons firing up to 120 rounds of 3-inch gun shots, or 100 & \\
$\quad$ rounds from 20-millimeter guns for each annually & \\
\hline
\end{tabular}

\subsection{VEHICLE USAGE}

During a typical year, ACF activity includes approximately 48,280.3 kilometer (km) $(30,000$ miles) of vehicular movement (this estimate is derived from information described below), predominantly light vehicles used to transport SNL test personnel or test customers from the ACF offices in Technical Area III (TA-III) to the ACF. A small number of heavy construction support vehicles are used to transport test articles or used to prepare the ACF test areas for specialized testing. These vehicles include:

- Light vehicles (up to 1-ton truck); estimated daily usage is 6 vehicles round-trip along paved roads from TA-III to Building 9925 and along unimproved roads from 
Building 9925 to the ACF. One way trip distance is slightly more than $12.9 \mathrm{~km}$ ( 8 miles). Annual usage is an estimated $43,935 \mathrm{~km}$ (27,300 miles).

- Contractor/test customers light vehicles. Daily usage is slightly more than one round-trip, annual frequency is 240 trips, and annual usage is an estimated $3,862 \mathrm{~km}$ (2,400 miles).

- Heavy vehicles, including lowboys, cranes, and similar items, with an estimated annual frequency of 30 trips, and annual usage is an estimated $483 \mathrm{~km}$ ( 300 miles).

\subsection{PERSONNEL}

Approximately $15 \mathrm{SNL}$ contractor employees are working at the facility on a regular basis. They report to the ACF project office in TA-III some $13.2 \mathrm{~km}$ ( 8.2 miles) away and drive to Building 9831 and the ACF during working hours. As many as 20 people, including transient test observers, may work at the facility during peak testing activity.

\subsection{UTILITIES}

Commercial electric power is available only at the Control Building (9831) and at the Winch Site. Only Buildings 9831 and 9832 (Explosives Assembly Building) are heated using propane heaters; the other buildings are unheated. Instrumentation and test control equipment items are electrically powered by portable motor generators brought to the site on an as-needed basis. The Instrumentation Bunker (9834) uses a $60 \mathrm{~kW}$ diesel-powered generator to provide electricity for heating, lighting, and instrumentation. The Explosive Assembly Building (9832) uses a $25 \mathrm{~kW}$ diesel-powered generator; however, an electrical power system is proposed to provide commercial power to this building. 
This page intentionally left blank. 


\subsection{SUMMARY OF SURVEY METHODS}

\subsection{OVERALL SURVEY METHODS}

The biological assessment was conducted during the periods of late September through October, 1991. Although this survey was late in the growing season when many flowering plants were initiating dormancy, it was seasonally timely enough to allow observations of the presence of Threatened, Endangered, Sensitive, or unique species of plants and animals, and to determine the general habitat characteristics of species associated with different elevations and drainage basin conditions within the local area. Lists of plant and animal species occurring and potentially occurring within the $\mathrm{ACF}$ area [Appendices $\mathrm{A}$ and $\mathrm{B}$ (plants) and $\mathrm{E}$ and $\mathrm{F}$ (animals)] were compiled from field surveys and previously conducted biological inventories of the surrounding area (Martin and Wagner, 1974; Fischer, 1990; Biggs, 1991).

Although many species of migrating birds had already left the area due to the timing of the survey, suitable habitat for nesting, perching, roosting, and foraging was recorded. Additionally, all species of wildlife visually observed were recorded. These data also included the presence of different species as discerned by observing tracks, scat, burrow systems, and nests-bones in carnivore scat and those found in association with woodrat nests are particularly good indicators of small mammal species composition in the local area. Major vegetation communities occurring in the vicinity of the biological study area also were mapped.

One-hundred percent surveys of species of special concern were conducted in 14 key areas and their connecting roadways (Figure 3 ). Total acreage covered by the 100 percent surveys was approximately 2,000 acres. Additionally, 13 sampling transects (including one trap-line for small mammals) were conducted in undisturbed natural areas within the biological study area. Each vegetation and bird transect was 1,000 meters (3,281 feet) in length (see Sections 2.2 and 2.3 on vegetation and bird sampling methods). A "buffer" zone approximately 402 meters wide ( 0.25 mile) surrounding virtually the entire biological study 
area also was surveyed by walking; the objective here was to identify any wildlife or unique ecological condition that was not directly associated with the 14 key survey areas discussed below.

The 14 key areas are identified and labeled (Figure. 3, Table 1): (1) Sol se Mete Spring and Canyon, (2) East Anchor Access Road, (3) East Anchor Site, (4) Rocket Sled Track, (5) North Arena, (6) East Instrumentation Site and Access Road, (7) West Anchor Access Road, (8) West Anchor Site, (9) South Arena, (10) Winch Sites, (11) West Instrumentation Sites, (12) Explosive Assembly Building, (13) Control Building, (14) Lurance Canyon Road and vicinity.

A qualified raptor expert, Roger Skaggs, performed a reconnaissance survey for the Mexican spotted owl within the ACF, and his report is included as Appendix I.

\subsection{PLANT TRANSECTS}

The line-intercept technique (Smith, 1980; Brower, et al., 1989) was used to sample vegetation in the biological study area. Data were tabulated on the basis of plants lying on a straight line cutting across different regions of the study area under investigation. Because an area was not being sampled, only species composition and relative estimates of density can be calculated. Line-intercept transects have been used widely in grassland-woodland community studies because true estimates of absolute density either cannot be made or are difficult to interpret due to the problem of distinguishing between individual plants. In situations where relative estimates are sufficient, line-intercept transects may efficiently obtain them.

Objectives of the line-intercept sampling were two-fold: (1) determine species composition in a given habitat, and (2) assess any community transition or ecological gradient that might exist in the selected study area. To accomplish both objectives, the directional orientation of the line-intercept transects were determined by connecting two randomly selected points in 
Table 1. Aerial Cable Facility areas included in the biological survey and acres surveyed.

\begin{tabular}{|c|c|}
\hline LOCATION & TOTAL ACRES SURVEYED \\
\hline \multicolumn{2}{|l|}{ Aerial Cable Facility Location } \\
\hline 1. Sol se Mete Canyon & 450 \\
\hline 2. East Anchor Access Road & 100 \\
\hline 3. East Anchor Site & 10 \\
\hline 4. Rocket Sled Track & 220 \\
\hline 5. North Arena & 160 \\
\hline $\begin{array}{l}\text { 6. East Instrumentation Site and } \\
\text { Access Road }\end{array}$ & 30 \\
\hline 7. West Anchor Access Road & 50 \\
\hline 8. West Anchor Site & 70 \\
\hline 9. South Arena & 800 \\
\hline 10. Winch Sites & 50 \\
\hline 11. West Instrumentation Sites & 20 \\
\hline 12. Explosive Assembly Building & 10 \\
\hline 13. Control Building & 10 \\
\hline $\begin{array}{l}\text { 14. Lurance Canyon Road and } \\
\text { vicinity }\end{array}$ & 300 \\
\hline Subtotal & 2,280 \\
\hline \multicolumn{2}{|l|}{ Specialized Surveys } \\
\hline Sol se Mete Spring Area & 160 \\
\hline Coyote Springs Area & 160 \\
\hline Systematic Transects & 1,240 \\
\hline Subtotal & 1,560 \\
\hline Grand Total & 3,840 \\
\hline
\end{tabular}


each sample area associated with specific ACF facilities. In each sample area, two 1,000-meter (3,281-foot) line-intercept transects were sampled, including: (1) one midelevation line-intercept transect lying primarily within woodland habitat, and (2) one lowelevation line-intercept transect primarily associated with the ecotone between grassland and woodland habitats. Each line-intercept transect ran horizontally (north-south) along the longaxis of each sample area, and samples were taken at 5-meter (16.4-foot) intervals (200 individual data points per 1000 -meter $(3,281$-foot) transect). Plants were counted if (1) they were physically touched by the line-intercept transect vector, or (2) their aerial foliage overlay the line-intercept transect vector. No attempt was made to estimate percent coverage-that portion of the line-intercept transect length touched by the plant measured at or near the base of the plant (or clump of grass), or by a perpendicular projection of its foliage intercepted by the line. Given the dispersion pattern of plant assemblages throughout the entire biological study area, it is unlikely that quadrant or belt-transect sampling methods would have yielded estimates of species composition that differed significantly $(P<0.05)$ from the line-intercept method employed herein.

\subsection{BIRD TRANSECTS}

A strip census (line transect) was used to sample bird species composition and density in selected regions of the biological study area-this procedure is used widely by terrestrial vertebrate biologists/ecologists (Caughley, 1977; Brower, et al., 1989; Smith, 1980). Objectives of the strip census sampling procedure were to determine baseline species composition and density estimates of birds in all major habitat types found in the biological study area.

To accomplish these objectives, the directional orientation of each strip census was determined by connecting two randomly selected points in each sample area. Targeted sample areas included the three major plant assemblages found in the biological study area: (1) grassland-juniper vegetation, (2) arroyo vegetation, and (3) piñon pine-juniper woodland vegetation. In each of the three major vegetation types, two strip census transects were 
sampled by walking a line 1,000 meters $(3,281$ feet) long and recording individuals observed from that line, and the distance to each animal observed. The two strip census were conducted one week apart, in the early morning [0700 hours (h)] beginning the first week of October. Many methods have been suggested for estimating density from strip censuses (Caughley, 1977; Brower, et al., 1989; Smith, 1980). Therefore, three of the most commonly used methods, each with somewhat different assumptions, were employed:

\section{D1 (Transect of Indefinite Width)$$
\mathrm{D} 1=\mathrm{N}(\mathrm{K}+1)^{2} / 4 \mathrm{LXK}(\mathrm{K}+2)
$$

where $\mathbf{D 1}=$ density, $\mathrm{N}=$ total number of animals observed, $\mathrm{K}=3.444$ (a constant reflecting the shape of a curve describing the theoretical probability of seeing an animal at varying distances from the line of march); $\mathbf{X}=$ mean of the right-angle distances from the line; and $\mathbf{L}=$ total length of the transect [i.e. 2,000 meters (6,561.6 feet)]. Because D1 always gives the most conservative estimate of density, it was used as the basis for recommendations concerning resource management, mitigation, and reclamation issues associated with ACF biological study areas.

\section{D2 (Transect of Fixed Width)$$
\text { D2 =n1 / L(W), }
$$

where $\mathbf{D 2}=$ density, $\mathbf{n 1}=$ number of birds observed in the first distance interval [10 meters (32.8 feet) from the line of march] used to define the width of the strip, and $\mathbf{W}=\mathrm{a}$ transect width of 20 meters (65.6 feet) [ 10 meters ( 32.8 feet) on either side of the line of march]. The first distance interval is used to define the width of the strip, because it is assumed that all animals will be observed in this strip, whereas, animals might be missed in the 20- to 30-meter (65.6- to 98.4-foot) distance intervals. 


\section{D3 (No Bounding Distance) \\ D3=N / 2LX;}

This model assumes that the probability of sighting falls away exponentially with distance; therefore, no bounding distance need be assumed. There are theoretical reasons for suspecting that this model is appropriate when detection depends on visibility rather than on behavior of animals (Hoglund, et al., 1967; Eberhardt, 1968; Caughley, 1977).

In all density estimates associated with the strip-census approach, data recorded are a population index rather than an absolute measure of density. Strip-census methods can be quantified to yield density estimates useful in studies where animals are highly mobile, yet often difficult to see until flushed. Strip-census methods assume that there is either a random distribution of individuals over the area sampled or that the transect line is located randomly in the targeted area, that all members (i.e., of both sexes and all ages) are equally likely to be flushed, that the sighting of one animal does not influence sighting of other animals, and that no animal is counted more than once. This census technique can be applied to birds as well as medium-sized animals (e.g., rabbit, rock squirrel, quail, etc.) in a variety of habitats, and gives fairly reliable information on population density.

\subsection{FIELD TECHNIQUES FOR SMALL MAMMAL TRAPPING}

Small mammals were surveyed by trapping using Sherman livetraps. A 1,371.6-meter (4,500-foot) trapline consisting of 300 Sherman livetraps, each spaced 4.5 meters (15 feet) apart, was set along a straight line in a designated area. All trapping was conducted over a three-consecutive-day period during the first week of October 1991. Traps were set in the evening, baited with rolled oats, and checked the following morning. 


\subsection{SPECIFIC SITES SURVEYED}

\subsection{SOL SE METE CANYON}

The biological survey of the unimproved Anchor Site Access Road encompassed three major biotic communities, and traversed a gradient in altitude ranging from 2,067 meters (6,782 feet; entrance to Lurance Canyon) to 2,377.4 meters (7,800 feet); near Manzano Lookout Tower, NW 1/4 Sec 34 and SW 1/4 Sec 27). These biotic communities included Great Basin Grassland, Great Basin Woodland, and Great Basin Conifer Woodland (Brown and Lowe, 1982). Sol se Mete Canyon (1,889.8 - 2,011.7 meters; 6,200 - 6,600 feet) and its associated drainages and arroyos lie primarily within the Great Basin Grassland vegetative community. Major vegetation along the lower lying regions of the Sol se Mete Canyon included a combination of various woody shrubs and grasses. The major trees, shrubs, and succulents included one-seed juniper, piñon pine, mountain mahogany, Apache plume, fourwing saltbush, yucca, prickly pear, tamarisk, and winter-fat; whereas the major grasses included grama, dropseed, three-awn, wheatgrass, galleta, muhly, and indian ricegrass.

No Threatened, Endangered, or Sensitive species of plants or animals were observed along this roadway.

\subsection{JUNCTION BETWEEN EAST AND WEST FORKS OF THE ANCHOR SITE ACCESS ROAD}

At the center of Sol se Mete Canyon (NE 1/4 Sec 29), the unimproved Anchor Site Access Road leaves the arroyo (2,011.7 meters, 6,600 feet) and ascends abruptly to an elevation of $2,072.6$ meters $(6,800$ feet) where it forks into an eastern and western branch. At this junction or saddle between the two 2,133.6-meter (7,000-foot) elevational contours associated with the upper regions of both east and west forks of the roadway is a plateau overlooking Sol se Mete Canyon to the north and Mount Washington to the southeast (SW 1/4 Sec 29; Figure 7). 


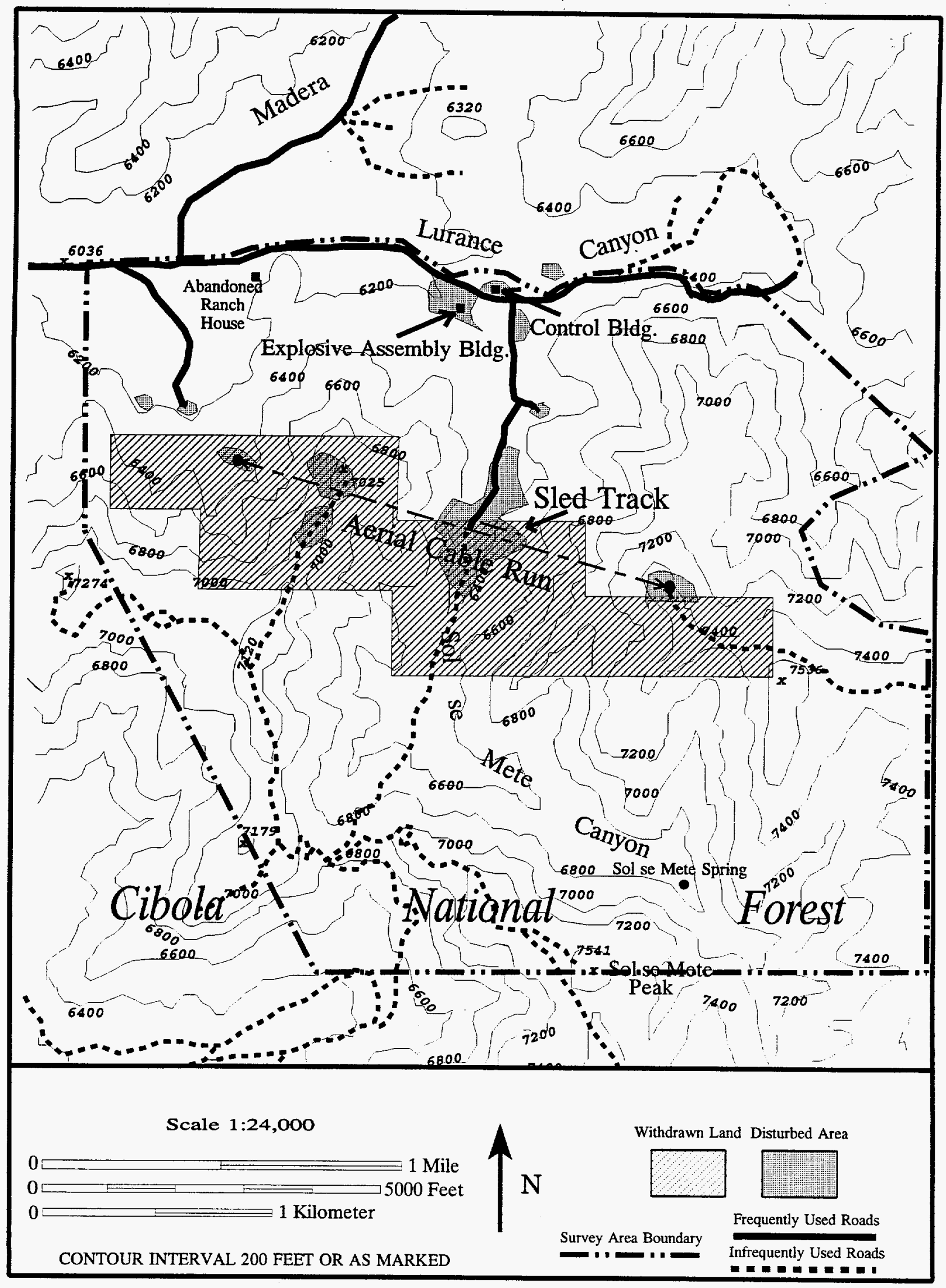

Figure 7. Project area in Sol se Mete Canyon and major topographic features 
A strip measuring 30.5 meters (100 feet) on both sides of the center line of the roadway was surveyed (100 percent) by walking. In this saddle and along the grassy fringe of the east fork of the roadway were numerous $(\underline{N}=37)$ pincushion cacti (Coryphantha spp.). In addition, two individual pincushion cacti were observed and photographed in this area that were tentatively identified as pineapple cactus or white flowered visnagita (Neolloydia intertexta) (Martin and Wagner, 1974; Fischer, 1990). This is a State of New Mexico Endangered (Group 3) species. Although widespread in New Mexico, this species of cactus is significantly reduced so that survival in New Mexico is jeopardized, primarily as a result of over-collecting. In New Mexico, this species normally blooms and produces seeds in July. Both individuals were within 15.2 meters (50 feet) of the existing roadway along the East Anchor Access Road. This is the only location within the 3,840 acre survey area where this species potentially was detected. Positive identification of these individual pincushion cacti should be made during the flowering season (July); therefore, an additional follow-on survey is recommended for late June or July, as required.

\subsection{EAST ANCHOR ACCESS ROAD}

The entire length of the unimproved dirt East Anchor Access Road leading from Lurance Canyon to the East Anchor Site was surveyed during the biological assessment (Figures 3 and 7). This area includes a distance of approximately $7.2 \mathrm{~km}$ ( 4.5 miles), and extends from Lurance Canyon (NE 1/4 Sec 17) south through Sol se Mete Canyon (Secs 20 and 29), southeast toward Mount Washington (Sec 33), east toward Manzano Lookout Tower (NW 1/4 Sec 34), and northwest to the East Anchor Site (SW 1/4 Sec 21). A strip measuring 30.5 meters (100 feet) on both sides of the center line of the roadway was surveyed (100 percent) by walking.

The East Anchor Site Access Road passes southeast to near Sol se Mete Peak as it ascends gradually to 2,316 meters (7,600 feet) at the north end of Mount Washington (NW 1/4 Sec 33). The eastern fork then bends sharply northeast near the Manzano Lookout Tower (NW 1/4 Sec 34) to an elevation of 2,377 meters $(7,800$ feet). The roadway then swings 
north the entire length of $\operatorname{Sec} 27$ and within the 2,316 meters (7,600 feet) elevational contour; it then turns northwest (NW 1/4 Sec 27) as it descends to 2,255.5 meters (7,400 feet) at the East Anchor Site (Figure 7). Between 2011.7 meters (6,600 feet) and 2,377.4 meters (7,800 feet) in elevation, the eastern fork of the Anchor Site Access Road falls well within the Great Basin Woodland Biotic Community (Brown and Lowe, 1982; Secs $29,28,33,27$, and 21). The primary species of trees associated with this vegetative community includes dense and mature stands of one-seed juniper and piñon pine. Other shrubs, succulents, and cacti include scrub live-oak, squaw brush, mountain mahogany, Apache plume, banana yucca, prickly pear cactus, and hedgehog cactus (Appendices A and $B)$.

Where the East Anchor Site Access Road passes northeast near the Manzano Lookout Tower (NW 1/4 Sec 34) at an elevation of 2377.4 meters (7,800 feet), the roadway enters Ponderosa pine and oak woodland. About $0.8 \mathrm{~km}(0.5 \mathrm{mile})$ of access road passes through this macrohabitat type. The primary species of vegetation associated with this vegetative community included Ponderosa pine, Gambel oak, New Mexico locust, scrub live-oak, Rocky Mountain juniper, one-seed juniper, piñon pine, wax current, wild rose, and mountain mahogany.

No Threatened. Endangered, or Sensitive species of plants or animals were observed along this roadway.

\subsection{WEST ANCHOR ACCESS ROAD AND WEST ANCHOR SITE}

The West Anchor Access Road continues up in elevation and out of Sol se Mete Canyon approximately $2.2 \mathrm{~km}$ (1.4 miles) along the 2,133.6-meter (7,000-foot) elevational contour as it bends northwest; it ends at the West Anchor Site (NW 1/4 Sec 20) overlooking the Rocket Sled Track and South Arena to the east, and the Winch Site for the South Arena to the northwest (Figures 3 and 7). The primary vegetation associated with the West Anchor. Site Access Road includes dense and mature stands of one-seed juniper, piñon pine, scrub 
live-oak, squaw brush, mountain mahogany, Apache plume, banana yucca, prickly pear cactus, and hedgehog cactus.

At an elevation of 2,133.6 meters (7,000 feet) along the NW 1/4 of Sec. 29, the western fork of the roadway passes across a flat ridgetop or mesa. In this area, and along both sides of the roadway in the flat and grassy areas, were numerous individual pincushion cacti (Coryphantha spp., Coryphantha vivipara; $\underline{N}=120$ specimens). A strip measuring 30.5 meters (100 feet) on both sides of the center line of the roadway was surveyed (100 percent) by walking.

No Threatened, Endangered, or Sensitive species of plants or animals were observed along this roadway.

\subsection{EAST ANCHOR SITE}

The East Anchor for the South Arena lies in a highly disturbed area surrounded by piñon pine-juniper woodland at 2,316.5-meter (7,600-foot) elevation (Figures 3 and 7). A strip extending 30.5 meters (100 feet) away from the perimeter of the disturbed East Anchor Site (including all disturbed areas) was surveyed 100 percent by walking. Species composition of the site consists of various grama grasses, three-awn grass, globemallow, snakeweed, and rabbitbrush. This area has a history of disturbance associated with building and road construction activities. Because the entire layer of natural woodland vegetation and soil has been removed, only weedy species of shrubs and other vegetation characteristic of disturbed habitat have invaded the site.

No Threatened, Endangered, or Sensitive species of plants or animals were observed in the immediate vicinity of the East Anchor Site and Access Road. 


\subsection{EAST SLOPE OF SOL SE METE CANYON, SOUTH ARENA, INCLUDING ROCKET SLED TRACK AND PROPOSED NEW CABLE SUPPORT STRUCTURE}

These areas are on the east slope of Sol se Mete Canyon directly below the East Anchor Site. Two 1,000-meter (3,218-foot) north-south vegetation transects were conducted at midelevation (2,042.2 meters; 6,700 feet) above the possible location of a new cable support structure, and horizontal to the existing steel cable (Figure 4). Results of these surveys show that vegetation at this elevation predominantly consists of trees (39 percent) and shrubs (11 percent), followed by grass ( 8 percent), cacti ( 6 percent), and several species of wildflowers ( 3 percent) (Table 2, Figure 8).

Two other 1,000-meter (3,281-foot) vegetation transects were also conducted at a lower elevation (1,920.2 meters; 6,300 feet) approximately level with a new cable support structure, but with the same north-south orientation and horizontal to the existing steel cable. These data show a different more arid-adapted composition of vegetation primarily consisting of grass ( 28 percent) and trees (20 percent), followed by shrubs (11 percent), cacti (8 percent), and wildflowers ( 2 percent) (Table 2, Figure 8). The Rocket Sled Track and new cable support structure are located in a highly disturbed area. Vegetation associated with this disturbed site included various grama grass species, three-awn grass, and vegetation typical of disturbed areas (e.g., Russian thistle, Chenopodium spp., dock, globemallow, snakeweed, rabbitbrush). A strip extending 30.5 meters (100 feet) away from the perimeter of the disturbed area associated with the Rocket Sled Track also was surveyed (100 percent) by walking.

No Threatened. Endangered. or Sensitive species of plants or animals were observed in the immediate vicinity of the Rocket Sled Track or the proposed New Cable Support Structure. 


\subsection{EAST INSTRUMENTATION SITE AND ACCESS ROAD}

A Camera Site and Access Road are located at the north end of Sol se Mete Canyon along the east slope of the canyon just south of Lurance Canyon Road and the Burn Site [approximately 2,072.6-meter (6,800-foot) elevation; Figure 3]. The entire length of the unimproved access road leading from Lurance Canyon to the East Instrumentation Site, and to the dead-end extension of this road above the East Instrumentation Site was surveyed during the biological assessment. A strip measuring 30.5 meters (100 feet) on both sides of the center line of the roadway was surveyed (100 percent) by walking. In addition, a strip extending 30.5 meters (100 feet) away from the perimeter of the disturbed area associated with the East Instrumentation Site was surveyed (100 percent) by walking. The primary species of shrubs associated with the East Instrumentation Site and Access Road included dense and mature stands of one-seed juniper and piñon pine. Other shrubs, succulents, and cacti included scrub live-oak, squaw brush, mountain mahogany, and Apache plume, banana yucca, prickly pear cactus, and hedgehog cactus.

No Threatened. Endangered, or Sensitive species of plants or animals were observed in the immediate vicinity of the East Instrumentation Site and Access Road. 
Table 2. Results of plant surveys using the line-intercept method (Brower, et al., 1989) in three different regions of the biological study area. Each transect included two 1,000-meter (3,218-foot) transects on either side of the ACF, but did not include any disturbed habitat. Total number of sample intervals per transect was 400 [5 meters (16.4 feet) between samples]. $\underline{N}=$ total number of individual per plant species sampled; $\underline{\%}=$ percent species composition along transect.

\begin{tabular}{|c|c|c|c|c|c|c|c|c|c|c|c|c|}
\hline \multirow[b]{3}{*}{ Species/Substrate } & \multicolumn{4}{|c|}{ East side Sol se Mete Canyon } & \multicolumn{4}{|c|}{ West side Sol se Mete Canyon } & \multicolumn{4}{|c|}{ Winch Site } \\
\hline & \multicolumn{2}{|c|}{ Mid-elevation } & \multicolumn{2}{|c|}{ Low-elevation } & \multicolumn{2}{|c|}{ Mid-elevation } & \multicolumn{2}{|c|}{ Low-elevation } & \multicolumn{2}{|c|}{ Mid-elevation } & \multicolumn{2}{|c|}{ Low-elevation } \\
\hline & $\mathrm{N}$ & $\%$ & $\mathbf{N}$ & $\%$ & $\mathrm{~N}$ & $\%$ & $\mathrm{~N}$ & $\%$ & $\mathbf{N}$ & $\%$ & $\mathbf{N}$ & $\%$ \\
\hline \multicolumn{13}{|l|}{ Rock and soil } \\
\hline ledge & 122 & 30.50 & 102 & 25.50 & 127 & 31.75 & 78 & 19.50 & 127 & 31.75 & 108 & 27.00 \\
\hline boulders & 8 & 2.00 & 10 & 2.50 & 3 & 0.75 & 0 & 0.00 & 10 & 2.50 & 14 & 3.50 \\
\hline soil & 4 & 1.00 & 14 & 3.50 & 4 & 1.00 & 52 & 13.00 & 0 & 0.00 & 4 & 1.00 \\
\hline \multicolumn{13}{|l|}{ Grasses } \\
\hline grama & 20 & 5.00 & 58 & 14.50 & 12 & 3.00 & 118 & 29.50 & 46 & 11.50 & 89 & 23.50 \\
\hline wheat & 8 & 2.00 & 32 & 8.00 & 90 & 22.50 & 34 & 8.50 & 10 & 2.50 & 2 & 0.50 \\
\hline stipa & 0 & 0.00 & 4 & 1.00 & 0 & 0.00 & 4 & 1.00 & 0 & 0.00 & 2 & 0.50 \\
\hline three-awn & 4 & 1.00 & 13 & 3.25 & 0 & 0.00 & 6 & 1.50 & 0 & 0.00 & 2 & 0.50 \\
\hline cotton top & 1 & 0.25 & 6 & 1.50 & 0 & 0.00 & 0 & 0.00 & 5 & 1.25 & 4 & 1.00 \\
\hline \multicolumn{13}{|l|}{ Wildflowers } \\
\hline primrose & 3 & 0.75 & 0 & 0.00 & 2 & 0.50 & 0 & 0.00 & 4 & 1.00 & 2 & 0.50 \\
\hline buckwheat & 8 & 2.00 & 4 & 1.00 & 0 & 0.00 & 0 & 0.00 & 4 & 1.00 & 2 & 0.50 \\
\hline
\end{tabular}




\begin{tabular}{|c|c|c|c|c|c|c|c|c|c|c|c|c|}
\hline \multirow[b]{3}{*}{ Species/Substrate } & \multicolumn{4}{|c|}{ East side Sol se Mete Canyon } & \multicolumn{4}{|c|}{ West side Sol se Mete Canyon } & \multicolumn{4}{|c|}{ Winch Site } \\
\hline & \multicolumn{2}{|c|}{ Mid-elevation } & \multicolumn{2}{|c|}{ Low-elevation } & \multicolumn{2}{|c|}{ Mid-elevation } & \multicolumn{2}{|c|}{ Low-elevation } & \multicolumn{2}{|c|}{ Mid-elevation } & \multicolumn{2}{|c|}{ Low-elevation } \\
\hline & $\mathrm{N}$ & $\%$ & $\mathrm{~N}$ & $\%$ & $\mathbf{N}$ & $\%$ & $\mathbf{N}$ & $\%$ & $\mathrm{~N}$ & $\%$ & $\mathrm{~N}$ & $\%$ \\
\hline bear grass & 8 & 2.00 & 2 & 0.50 & 0 & 0.00 & 0 & 0.00 & 5 & 1.25 & 2 & 0.50 \\
\hline composites spp. & 0 & 0.00 & 4 & 1.00 & 0 & 0.00 & 0 & 0.00 & 1 & 0.25 & 0 & 0.00 \\
\hline \multicolumn{13}{|l|}{ Cacti } \\
\hline claretcup cactus & 4 & 1.00 & 3 & 0.75 & 2 & 0.50 & 0 & 0.00 & 4 & 1.00 & 0 & 0.00 \\
\hline tree cholla & 0 & 0.00 & 14 & 3.50 & 2 & 0.50 & 4 & 1.00 & 0 & 0.00 & 4 & 1.00 \\
\hline prickly pear & 10 & 2.50 & 8 & 2.00 & 24 & 6.00 & 4 & 1.00 & 17 & 4.25 & 6 & 1.50 \\
\hline yucca & 6 & 1.50 & 4 & 1.00 & 2 & 0.50 & 2 & 0.50 & 8 & 2.00 & 0 & 0.00 \\
\hline \multicolumn{13}{|l|}{ Shrubs } \\
\hline four-wing saltbush & 0 & 0.00 & 8 & 2.00 & 20 & 5.00 & 8 & 2.00 & 0 & 0.00 & 6 & 1.50 \\
\hline winterfat & 5 & 1.25 & 7 & 1.75 & 14 & 3.50 & 0 & 0.00 & 9 & 2.25 & 10 & 2.50 \\
\hline sagebrush & 6 & 1.50 & 1 & 0.25 & 24 & 6.00 & 2 & 0.50 & 12 & 3.00 & 18 & 4.50 \\
\hline Apache plume & 6 & 1.50 & 8 & 2.00 & 0 & 0.00 & 0 & 0.00 & 9 & 2.25 & 6 & 1.50 \\
\hline broom snakeweed & 0 & 0.00 & 8 & 2.00 & 0 & 0.00 & 4 & 1.00 & 0 & 0.00 & 0 & 0.00 \\
\hline squawbrush & 5 & 1.25 & 2 & 0.50 & 18 & 4.50 & 2 & 0.50 & 5 & 1.25 & 2 & 0.50 \\
\hline mountain mahogany & 12 & 3.00 & 8 & 2.00 & 4 & 1.00 & 2 & 0.50 & 11 & 2.75 & 2 & 0.50 \\
\hline scrub live-oak & 8 & 2.00 & 2 & 0.50 & 0 & 0.00 & 0 & 0.00 & 5 & 1.25 & 0 & 0.00 \\
\hline
\end{tabular}




\begin{tabular}{|c|c|c|c|c|c|c|c|c|c|c|c|c|}
\hline \multirow[b]{3}{*}{ Species/Substrate } & \multicolumn{4}{|c|}{ East side Sol se Mete Canyon } & \multicolumn{4}{|c|}{ West side Sol se Mete Canyon } & \multicolumn{4}{|c|}{ Winch Site } \\
\hline & \multicolumn{2}{|c|}{ Mid-elevation } & \multicolumn{2}{|c|}{ Low-elevation } & \multicolumn{2}{|c|}{ Mid-elevation } & \multicolumn{2}{|c|}{ Low-elevation } & \multicolumn{2}{|c|}{ Mid-elevation } & \multicolumn{2}{|c|}{ Low-elevation } \\
\hline & $\mathrm{N}$ & $\%$ & $\mathrm{~N}$ & $\%$ & $\mathbf{N}$ & $\%$ & $\mathbf{N}$ & $\%$ & $\mathrm{~N}$ & $\%$ & $\mathrm{~N}$ & $\%$ \\
\hline \multicolumn{13}{|l|}{ Trees } \\
\hline one-seed juniper & 80 & 20.00 & 46 & 11.50 & 32 & 8.00 & 45 & 11.25 & 59 & 14.75 & 52 & 13.00 \\
\hline piñon pine & 72 & 18.00 & 32 & 8.00 & 20 & 5.00 & 35 & 8.75 & 49 & 12.25 & 58 & 14.50 \\
\hline
\end{tabular}




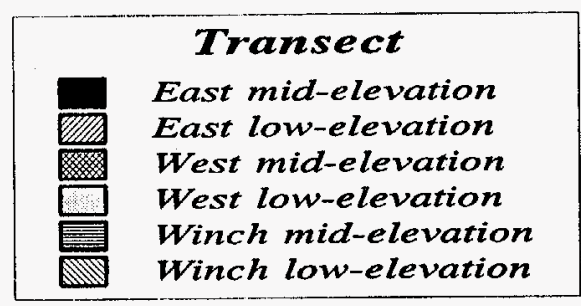

w

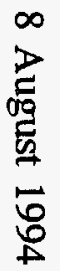

Frequency

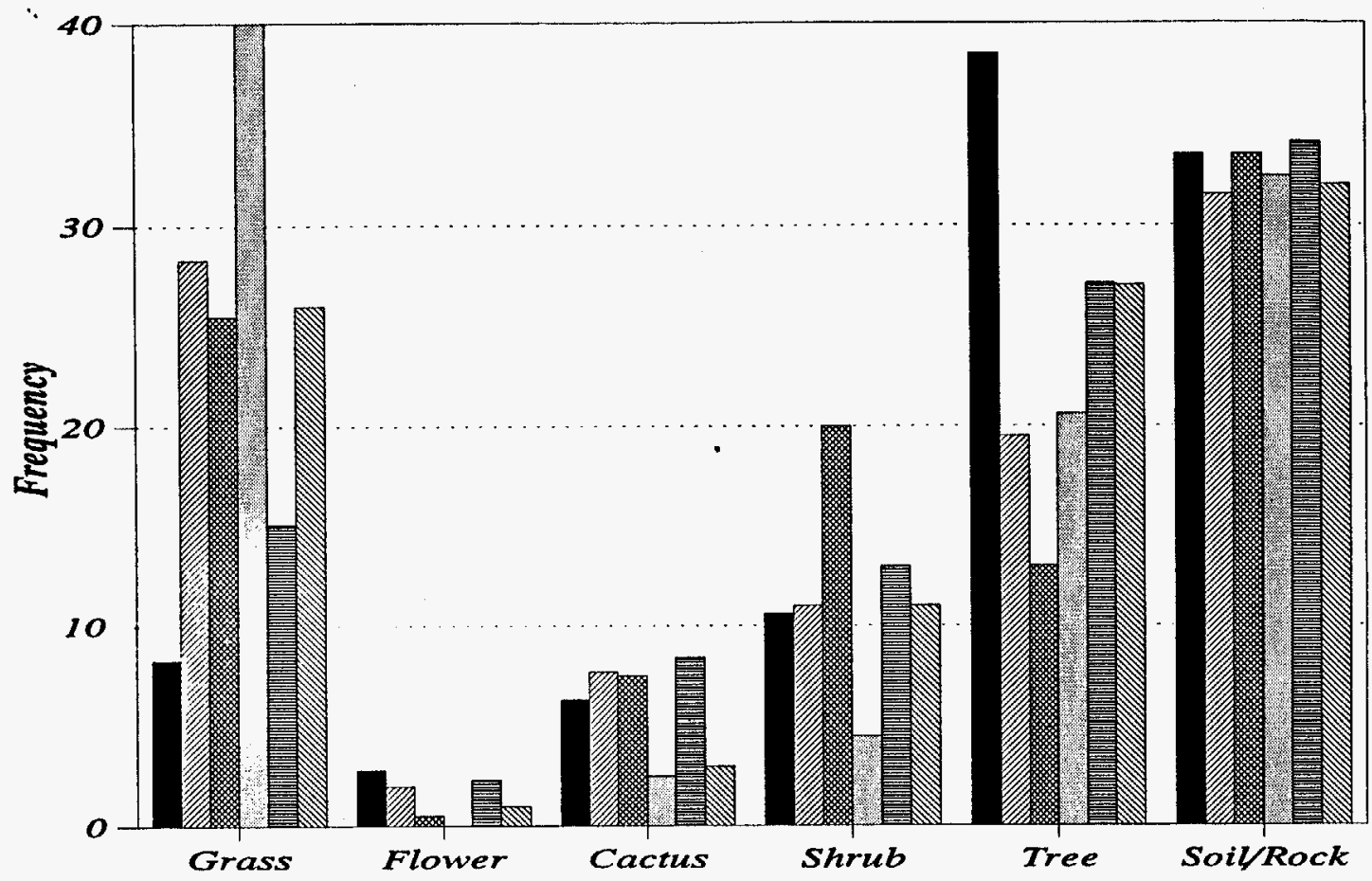

\begin{tabular}{|l|c|c|c|c|c|c|}
\hline East mid-elevation & 8.3 & 2.8 & 6.3 & 10.6 & 38.5 & 33.5 \\
\hline East low-elevation & 28.3 & 2.0 & 7.7 & 11.0 & 19.5 & 31.5 \\
\hline West mid-elevation & 25.5 & 0.5 & 7.5 & 20.0 & 13.0 & 33.5 \\
\hline West low-elevation & 40.0 & 0 & 2.5 & 4.5 & 20.6 & 32.4 \\
\hline Winch mid-elevation & 15.1 & 2.3 & 8.4 & 13.0 & 27.1 & 34.1 \\
\hline Winch low-elevation & 26.0 & 1.0 & 3.0 & 11.0 & 27.0 & 32.0 \\
\hline
\end{tabular}

Figure 8. Percent frequency of occurrence of different vegetation groups sampled along various plant transects in the ACF project area along the east and west sides of Sol se Mete Canyon and the west slope of the Winch Site 


\subsection{WEST SLOPE OF SOL SE METE CANYON, NORTH ARENA, INCLUDING WEST INSTRUMENTATION SITES, IMPACT AREA OF 3-INCH GUN, AND PROBABLE LOCATION OF NEW CABLE SUPPORT STRUCTURE}

These areas, highly disturbed from previous construction and road building activities, compared to the east slope of Sol se Mete Canyon, occur along the more arid and sparsely vegetated west slope of Sol se Mete Canyon directly below the West Anchor Site. Two 1,000 -meter $(3,218$-foot $)$ north-south vegetation transects were conducted at mid-elevation (2,072.6 meters; 6,800 feet) just below the possible location of the New Cable Support Structure, and horizontal to the existing steel cable (Figure 9). Results of these surveys show that vegetation at this elevation predominantly consists of grass (26 percent) and shrubs (20 percent), followed by trees (13 percent), cacti ( 8 percent), and several species of wildflowers (1 percent) (Table 2, Figure 8).

Two other 1,000-meter (3,281-foot) vegetation transects were also conducted at a low elevation (1,920.2 meters; 6,300 feet) just above the two West Instrumentation Sites and the Impact Area of the 3-inch Gun, but in a north-south orientation and horizontal to the existing steel cable (Figure 9). These data show a different composition of vegetation than exhibited by the mid-slope transects. The low elevation transects showed that species composition primarily consisted of grass (28 percent) and trees ( 20 percent), followed by shrubs (11 percent), cacti ( 8 percent), and wildflowers ( 2 percent) (Table 2 , Figure 8 ). In addition to vegetation transects, a strip extending 30.5 meters (100 feet) away from the perimeter of each of the West Instrumentation Sites and the Impact Area of the 3-inch Gun was surveyed (100 percent) by walking. Vegetation associated with these disturbed areas included various grama grass species, three-awn grass, globemallow, snakeweed, and rabbitbrush.

No Threatened, Endangered, or Sensitive species of plants or animals were observed in the immediate vicinity of the West Instrumentation Sites and the Impact Area of the 3-Inch Gun. 


\subsection{WEST ANCHOR SITE}

The West Anchor Site for the South Arena lies in a highly disturbed area surrounded by piñon pine-juniper woodland at 2141.2 meters $(7,025$ feet) in elevation (Figures 9 and 10). A strip extending 30.5 meters (100 feet) away from the entire perimeter of the West Anchor Site was surveyed (100 percent) by walking. Species composition associated with the West Anchor Site consists of various grama grasses, three-awn grass, Russian thistle, dock, globemallow, snakeweed, and rabbitbrush. This area has a history of disturbance associated with building and road construction activities. Because the entire layer of natural woodland vegetation and soil has been scraped off, only weedy species of shrubs and other vegetation characteristic of disturbed habitat have invaded the area.

No Threatened, Endangered, or Sensitive species of plants or animals were observed in the immediate vicinity of the West Anchor Site and Access Road.

\subsection{WINCH SITE FOR THE SOUTH ARENA AND ACCESS ROAD}

The Winch Site is located directly down-slope and northwest of the West Anchor Site at approximately 1889.8 meters $(6,200$ feet) in elevation (Figure 10$)$. An area extending 30.5 meters (100 feet) away from the entire perimeter of the Winch Site was surveyed (100 percent) by walking. Vegetation characteristic of this highly disturbed area includes assorted species of grass, juniper, piñon pine, and characteristic road-side vegetation (Russian thistle, dock, globemallow, snakeweed, rabbitbrush). This area has a history of disturbance associated with building and road construction activities. In addition, the dirt road adjacent to the Winch Site receives heavy vehicular traffic, and vehicle-generated dust adds to the disturbance.

North-south vegetation transects conducted at mid-elevation ( $2,072.6$ meters; 6,800 feet) near a new cable support structure and 90 degrees to the existing steel cable show that the vegetation at this elevation above the Winch Site predominantly consists of trees (27 percent), grass (15 percent), and shrubs (13 percent), followed by cacti ( 8 percent), and several species of wildflowers ( 2 percent) (Table 2, Figure 8 ). Two additional 1,000-meter 
( 3,281 foot) vegetation transects conducted at a lower elevation ( $1,920.2$ meters; 6,300 feet) show that the composition of vegetation primarily consists of trees (27 percent) and grassland (26 percent) (Table 2, Figure 8).

No Threatened, Endangered, or Sensitive species of plants or animals were observed in the immediate vicinity of the Winch Site.

\subsection{EXPLOSIVE ASSEMBLY BUILDING AND CONTROL BUILDING}

The Explosive Assembly Building (No. 9832) and parking lot area, and the Control Building (No. 9831) are located at the north entrance to Sol se Mete Canyon where it branches south from the Lurance Canyon Access Road (Figures 4 and 11). A 152.4-meter (500-foot) radius around each building was surveyed (100 percent) by walking for sensitive species of plants and animals. Additionally, all surrounding grassland habitat south of Lurance Canyon Road to the Winch Site was surveyed (100 percent) by walking.

No Threatened, Endangered, or Sensitive species of plants or animals were observed in the immediate vicinity of these buildings. Only scattered patches of daggerthorn cholla (O. clavata; a State of New Mexico Priority 1 species with no Federal status, see Section 5.0 Protected Species - Plants) were found growing east and west of the Explosive Assembly Building. This species was found in association with sandy and loamy soils vegetated predominantly by grama and three-awn grasses, occasional pincushion cacti, scattered juniper, a variety of shrubs generally associated with low elevation $(1,828.8$ meters; 6,000 feet) grassland and arroyo habitats (e.g., tree cholla, winterfat, four-wing saltbush), and disturbed road-side vegetation (Russian thistle, dock, globemallow, snakeweed, rabbitbrush).

The area around the Explosive Assembly and Control Buildings has a history of disturbance associated with facility and road construction activities (Figure 11). The dirt road adjacent to this area receives heavy vehicular, truck, and military traffic, because it provides the only access to ACF, Explosive Assembly Building, Control Building, the Burn Site, East and West Anchor Sites, and the wildlife drinker tanks along the east fork of Sol se Mete Canyon. 


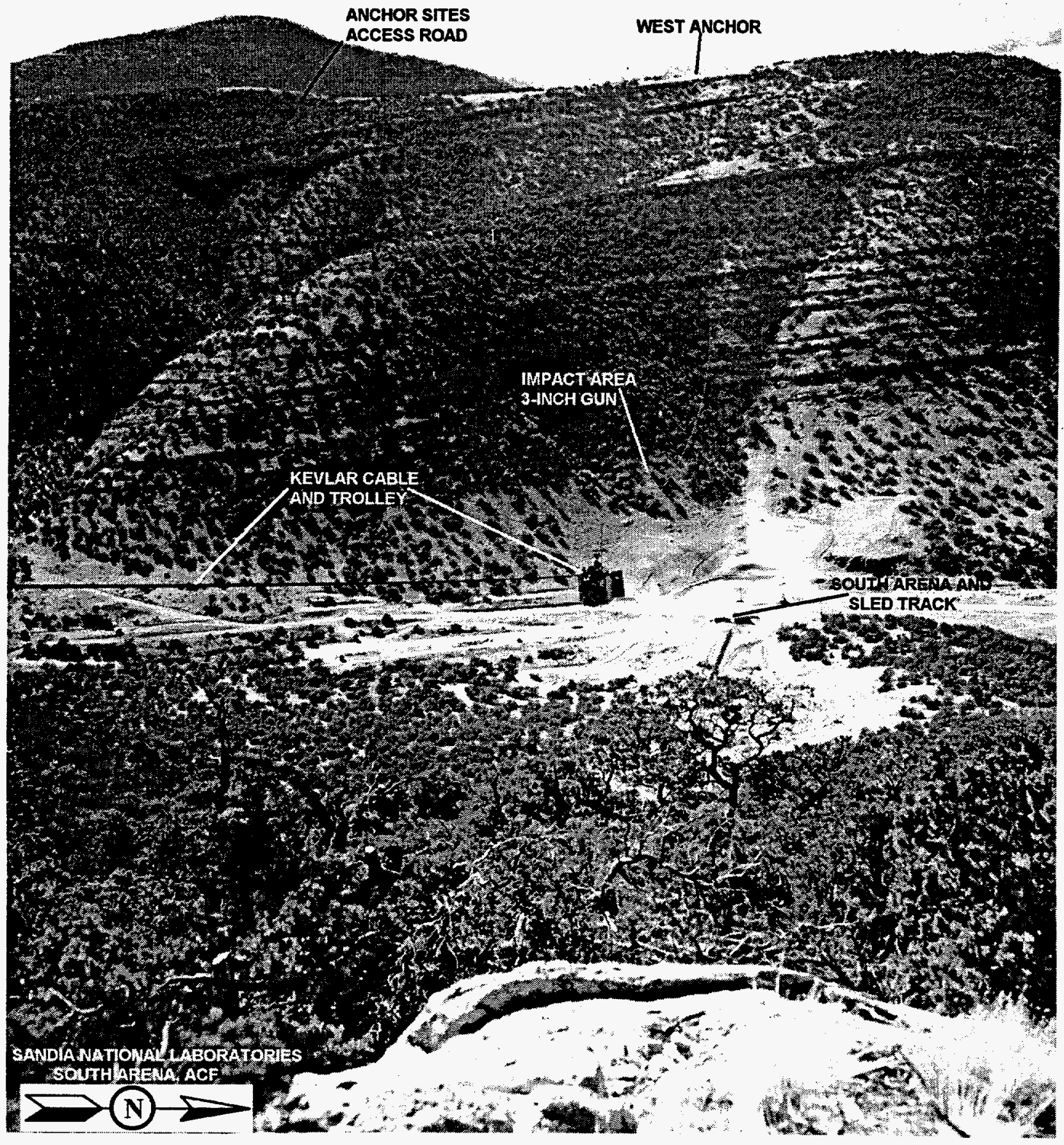

Figure 9. West facing slopes of ACF South Arena 


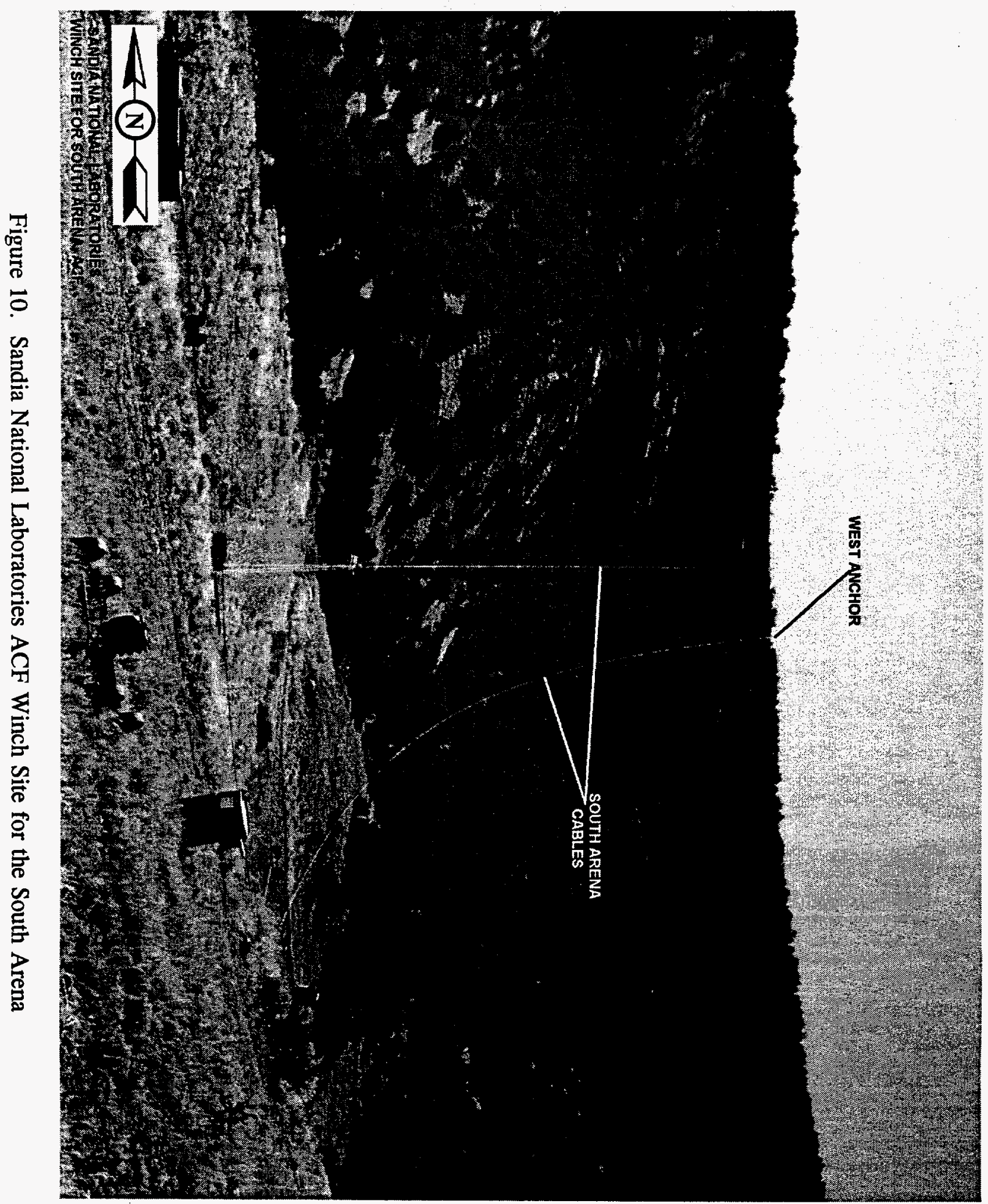




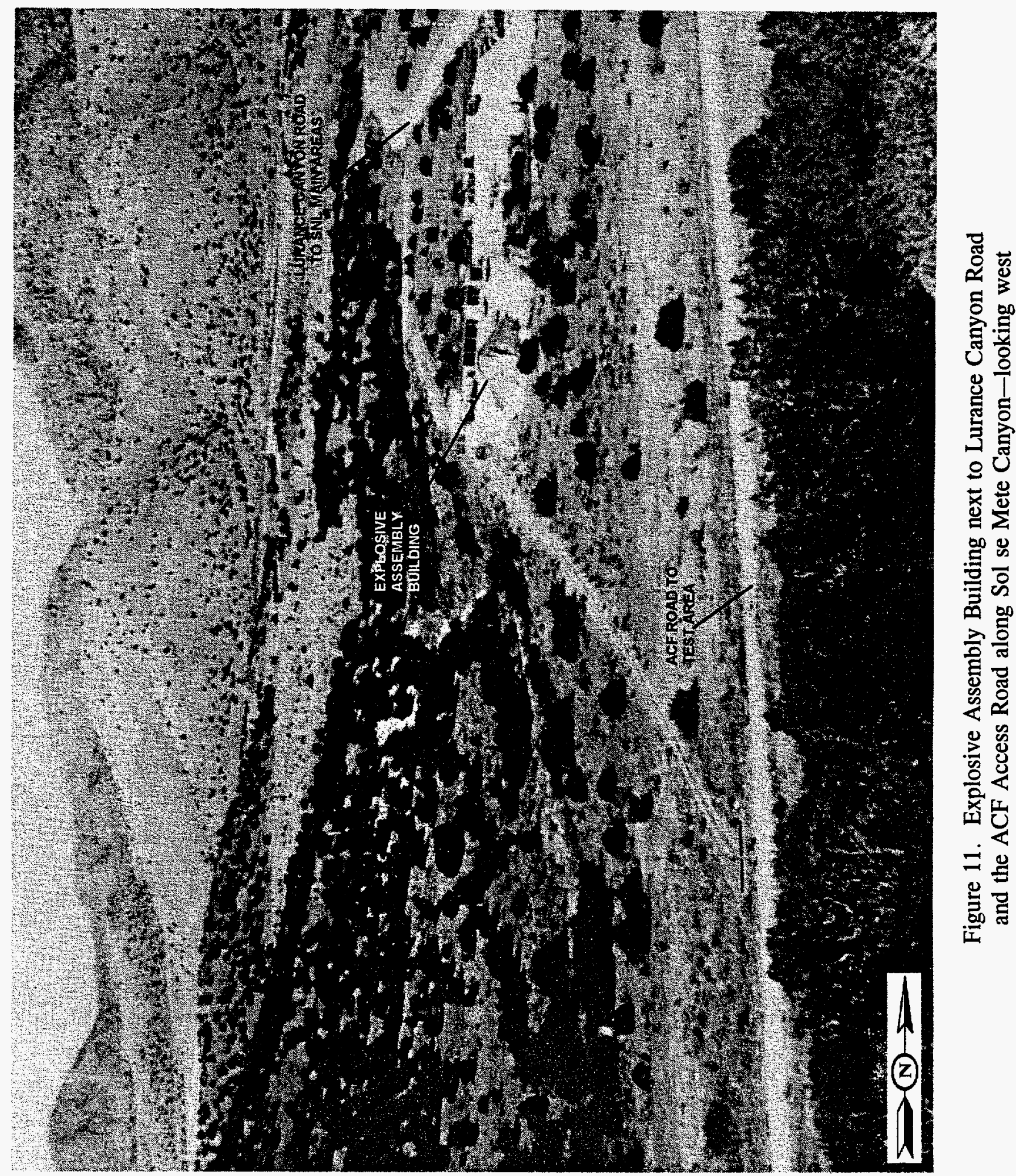




\subsection{SOL SE METE SPRING CANYON}

Sol se Mete Spring and three wildlife drinker tanks are located in an east fork of Sol se Mete Canyon, just south of the South Arena (Sec 29 and 28; Figure 12). The canyon leading to Sol se Mete Spring (1,889.8 meters; 6,200 feet) follows an arroyo and its associated drainages at the lower end of the canyon. This arroyo lies primarily within Great Basin Grassland and Woodland Communities and has species of plants and animals common to this major macrohabitat type. Along the low-lying elevations associated with the center of the arroyo, a combination of various woody shrubs, trees, and grasses are found including juniper, piñon pine, mountain mahogany, Apache plume, four-wing saltbush, yucca, prickly pear, tamarisk, and winter-fat; the major grasses included grama, dropseed, three-awn, wheatgrass, galleta, muhly, and indian ricegrass.

Along the more arid southern exposure of the canyon, the primary species of plants include dense and mature stands of one-seed juniper and piñon pine. Other shrubs and cacti included scrub live-oak, squaw brush, mountain mahogany, Apache plume, banana yucca, prickly pear cactus, and hedgehog cactus. Along the more mesic northern exposure of this canyon and east towards Sol se Mete Spring the primary species of plants associated with this community included Gambel oak, New Mexico locust, scrub live-oak, Rocky Mountain juniper, juniper, piñon pine, wax current, and mountain mahogany. A strip (30.5 meters (100 feet) on both sides of the center line of the roadway that passes up the center of the canyon was surveyed (100 percent) by walking.

At the eastern entrance to Sol se Mete Spring Canyon (Figure 12), one gray vireo (Vireo vicinior) was observed on two consecutive days (3-4 October 1991) in piñon pine-juniper woodland near the lower drinker tank located at the entrance to the Sol se Mete Springs Canyon leading to Sol se Mete Spring. The gray vireo is a State of New Mexico Endangered species (Group 2). This species was not observed in any other part of the biological study area subsequent to these first two sightings (see Section 6.0 Protected Species - Animals). 


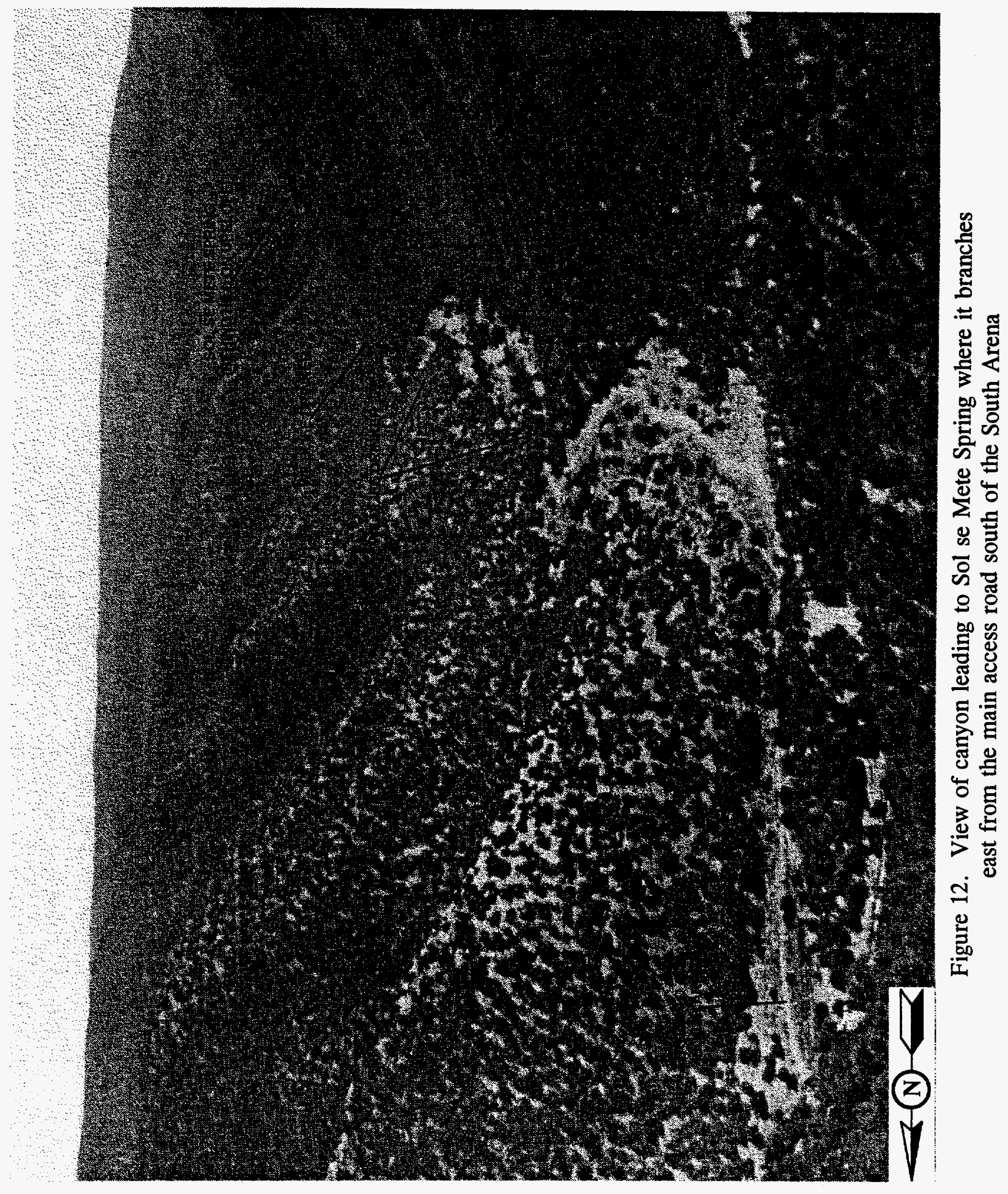


No other Threatened. Endangered, or Sensitive species of animal was observed in Sol se Mete Spring Canyon.

\subsection{LURANCE CANYON ROAD AND VICINITY}

Both sides of Lurance Canyon Road, from the turnoff from near the south end of the Explosive Assembly Building and associated arroyo to the East Instrumentation Site and Access Road (Figure 3), was surveyed 100 percent. A strip measuring 30.5 meters (100 feet) on both sides of the center line of the roadway was surveyed by walking. No Threatened, Endangered, or Sensitive species of plants or animals were observed in the immediate vicinity of this road. Only scattered patches of daggerthorn cholla (O. clavata; a State of New Mexico Priority 1 species with no Federal status, see Section 5.0 Protected Species Plants) were found growing along the south side of the roadway. This species was found in association with sandy and loamy soils vegetated predominantly by grama and three-awn grasses, occasional pincushion cacti, scattered juniper, a variety of shrubs generally associated with low elevation (1,828.8 meters; 6,000 feet) grassland and arroyo habitats (e.g., tree cholla, winterfat, four-wing saltbush), and disturbed road-side vegetation (Russian thistle, dock, globemallow, snakeweed, rabbitbrush). 


\subsection{WILDLIFE}

\subsection{BIRDS}

By far, the greatest species diversity (richness) and density of birds (insectivorous, perching, and raptoral) were observed during surveys of arroyo vegetation along drainages at the edges of the grassland-juniper, and piñon pine-juniper-oak woodland vegetation assemblages (Appendices C and D; Figures 13, 14, and 15). Arroyo vegetation had the greatest concentration of potential shelters, water sources (ephemeral and permanent), food types (e.g., vegetation diversity), perching sites (e.g., for raptors), sites for territorial displays (e.g., Townsend's solitaires), and potential nesting sites. Additionally, at some time during the day most species of birds (irrespective of vegetation affiliation) were attracted to the ephemeral or permanent water sources available in arroyo habitats, particularly at Sol se Mete Spring and the wildlife drinker tanks below the spring.

In grassland-juniper, arroyo, and woodland vegetation, small perching (passerine) and insectivorous birds comprised the largest segment of the overall species composition. Although grassland-juniper and woodland vegetation were very similar in total numbers of birds counted $(\underline{N}=75$ in grassland-juniper; $\underline{N}=73$ in woodlands), species compositions were very different. For example, Cooper's hawks, red-tailed hawks, red-shafted flickers, Clark's nutcrackers, scrub jays, piñon jays, nuthatches, mountain chickadees, rock wrens, and evening grosbeaks were common in woodlands; whereas American kestrels, loggerhead shrikes, rufous-sided towhees, brown towhees, chipping sparrows, and white-crowned sparrows were common in grassland-juniper vegetation (Table 3). In grassland-juniper habitat, chipping sparrows, Townsend's solitaires, and rufous-sided towhees were most abundant; in arroyo vegetation, Townsend's solitaires, white-crowned sparrows, and rufoussided towhees were most common; and in woodland vegetation, mountain chickadees, piñon jays, and Oregon juncos were most frequently observed. 
Table 3: Results of bird surveys in three different vegetation types. Total length of each transect was 2,000 meters. Surveys were conducted along transects using Eberhardt's (1968) model of density per unit area (Caughley, 1977:41; Brower, et al., 1989). $\underline{N}=$ total birds observed, and number of individuals in species $\underline{X}$ average distance from the transect (line-of-march); $\underline{D} 1, \underline{D 2}$, and D3 are different estimates of density (birds per $\mathrm{km}^{2}$; see text for details of the methods).

\begin{tabular}{|c|c|c|c|c|c|c|c|c|c|c|c|c|c|c|c|}
\hline \multirow[b]{2}{*}{ Species } & \multicolumn{5}{|c|}{ Grassland-juniper vegetation } & \multicolumn{5}{|c|}{ Arroyo vegetation } & \multicolumn{5}{|c|}{ Piñon pine-juniper-oak woodland } \\
\hline & $\mathrm{N}=75$ & $\underline{x}$ & $\underline{\mathrm{D} 1}$ & $\underline{\mathrm{D} 2}$ & $\underline{\mathrm{D} 3}$ & $\mathrm{~N}=180$ & $\underline{\mathrm{X}}$ & $\underline{\mathrm{D} 1}$ & $\underline{\mathrm{D} 2}$ & $\underline{\text { D3 }}$ & $\mathrm{N}=73$ & $\underline{\mathbf{x}}$ & $\underline{\mathrm{D} 1}$ & $\underline{\mathrm{D} 2}$ & $\underline{\mathrm{D} 3}$ \\
\hline sharp-shinned hawk & - & - & - & - & - & 2 & 30.0 & 8.8 & - & 16.7 & - & - & - & - & - \\
\hline Cooper's hawk & - & - & - & - & - & 2 & 30.0 & 8.8 & - & 16.7 & 4 & 21.3 & 24.8 & 25.0 & 47.1 \\
\hline red-tailed hawk & - & - & - & - & - & 4 & 30.0 & 17.5 & - & 33.3 & 2 & 15.0 & 17.6 & 25.0 & 33.3 \\
\hline American kestrel & 5 & 30.0 & 21.9 & - & 41.7 & - & - & - & - & - & - & - & - & - & - \\
\hline red-shafted flicker & - & - & - & - & - & 10 & 20.6 & 63.9 & 50.0 & 121.4 & 7 & 14.6 & 63.3 & 100.0 & 120.1 \\
\hline common raven & 4 & 25.0 & 21.1 & 25.0 & 40.0 & 5 & 26.0 & 25.3 & 25.0 & 48.1 & - & - & - & - & - \\
\hline Clark's nutcracker & - & - & - & - & - & - & - & - & - & - & 7 & 15.7 & 58.7 & 50.0 & 111.4 \\
\hline scrub jay & 7 & 17.7 & 52.0 & 50.0 & 98.8 & 10 & 16.0 & 82.2 & 100.0 & 156.3 & 7 & 14.1 & 65.2 & 25.0 & 123.7 \\
\hline pin̄on jay & - & - & - & - & - & 16 & 19.4 & 108.7 & 50.0 & 206.5 & 8 & 11.6 & 90.6 & 75.0 & 172.0 \\
\hline plain titmouse & - & - & - & - & - & - & - & - & - & - & 4 & 9.0 & 58.5 & 75.0 & 111.1 \\
\hline mountain chickadee & - & - & - & - & - & 10 & 10.0 & 131.7 & 250.0 & 250.0 & 8 & 8.9 & 118.7 & 125.0 & 225.3 \\
\hline red-breasted nuthatch & - & - & - & - & - & 6 & 7.0 & 112.9 & 150.0 & 214.3 & - & - & - & - & - \\
\hline rock wren & - & - & - & - & - & - & - & - & - & - & 4 & 12.3 & 43.0 & 25.0 & 81.6 \\
\hline ruby-crowned kinglet & - & - & - & - & - & - & - & - & - & - & - & - & - & - & - \\
\hline western bluebird & 8 & 18.8 & 56.2 & 50.0 & 106.7 & 10 & 11.1 & 119.7 & 125.0 & 227.3 & 一 & 一 & - & - & - \\
\hline Townsend's solitaire & 15 & 22.1 & 89.2 & 25.0 & 169.4 & 25 & 15.1 & 218.3 & 250.0 & 414.5 & 7 & 13.4 & 68.6 & 100.0 & 130.3 \\
\hline
\end{tabular}




\begin{tabular}{|c|c|c|c|c|c|c|c|c|c|c|c|c|c|c|c|}
\hline \multirow[b]{2}{*}{ Species } & \multicolumn{5}{|c|}{ Grassland-juniper vegetation } & \multicolumn{5}{|c|}{ Arroyo vegetation } & \multicolumn{5}{|c|}{ Piñon pine-juniper-oak woodland } \\
\hline & $\mathrm{N}=75$ & $\underline{X}$ & $\underline{\mathrm{D} 1}$ & $\underline{\mathrm{D} 2}$ & $\underline{\mathrm{D} 3}$ & $\mathrm{~N}=180$ & $\underline{\mathbf{X}}$ & $\underline{\mathrm{D} 1}$ & $\underline{\mathrm{D} 2}$ & $\underline{\mathrm{D} 3}$ & $\mathrm{~N}=73$ & $\underline{\mathbf{X}}$ & $\underline{\mathrm{D} 1}$ & $\underline{\mathrm{D} 2}$ & $\underline{\mathrm{D} 3}$ \\
\hline American robin & - & - & - & - & - & 21 & 15.1 & 182.6 & 125.0 & 346.7 & 4 & 15.0 & 35.1 & 50.0 & 66.7 \\
\hline loggerhead shrike & 4 & 24.8 & 21.3 & 25.0 & 40.4 & - & - & - & - & - & - & - & - & - & - \\
\hline evening grosbeak & - & - & - & - & - & - & - & - & - & - & - & 10.0 & 52.7 & 100.0 & 100.0 \\
\hline rufous-sided towhee & 7 & 11.0 & 83.8 & 25.0 & 159.1 & 12 & 10.0 & 158.0 & 200.0 & 300.0 & - & - & - & - & - \\
\hline brown towhee & 4 & 12.0 & 43.9 & 50.0 & 83.3 & 6 & 7.0 & 112.9 & 150.0 & 214.3 & - & - & - & - & - \\
\hline green-tailed towhee & - & - & - & - & - & 6 & 7.0 & 112.9 & 150.0 & 214.3 & - & - & - & - & - \\
\hline chipping sparrow & 10 & 8.9 & 147.9 & 175.0 & 280.9 & 6 & 9.3 & 85.0 & 125.0 & 160.7 & - & - & - & - & - \\
\hline white-crowned sparrow & 6 & 10.3 & 76.5 & 100.0 & 145.2 & 12 & 9.3 & 169.2 & 250.0 & 321.4 & - & - & - & - & - \\
\hline Oregon junco & 5 & 10.8 & 61.0 & 100.0 & 115.7 & 8 & 9.0 & 117.0 & 200.0 & 222.2 & 7 & 11.4 & 80.6 & 75.0 & 153.1 \\
\hline gray-headed junco & - & - & - & - & - & 9 & 23.1 & 51.3 & 25.0 & 97.4 & - & - & - & - & - \\
\hline Mean & & 17.4 & 61.3 & 62.5 & 116.5 & & 16.0 & 99.3 & 139.1 & 118.5 & & 13.3 & 59.8 & 65.4 & 113.5 \\
\hline
\end{tabular}




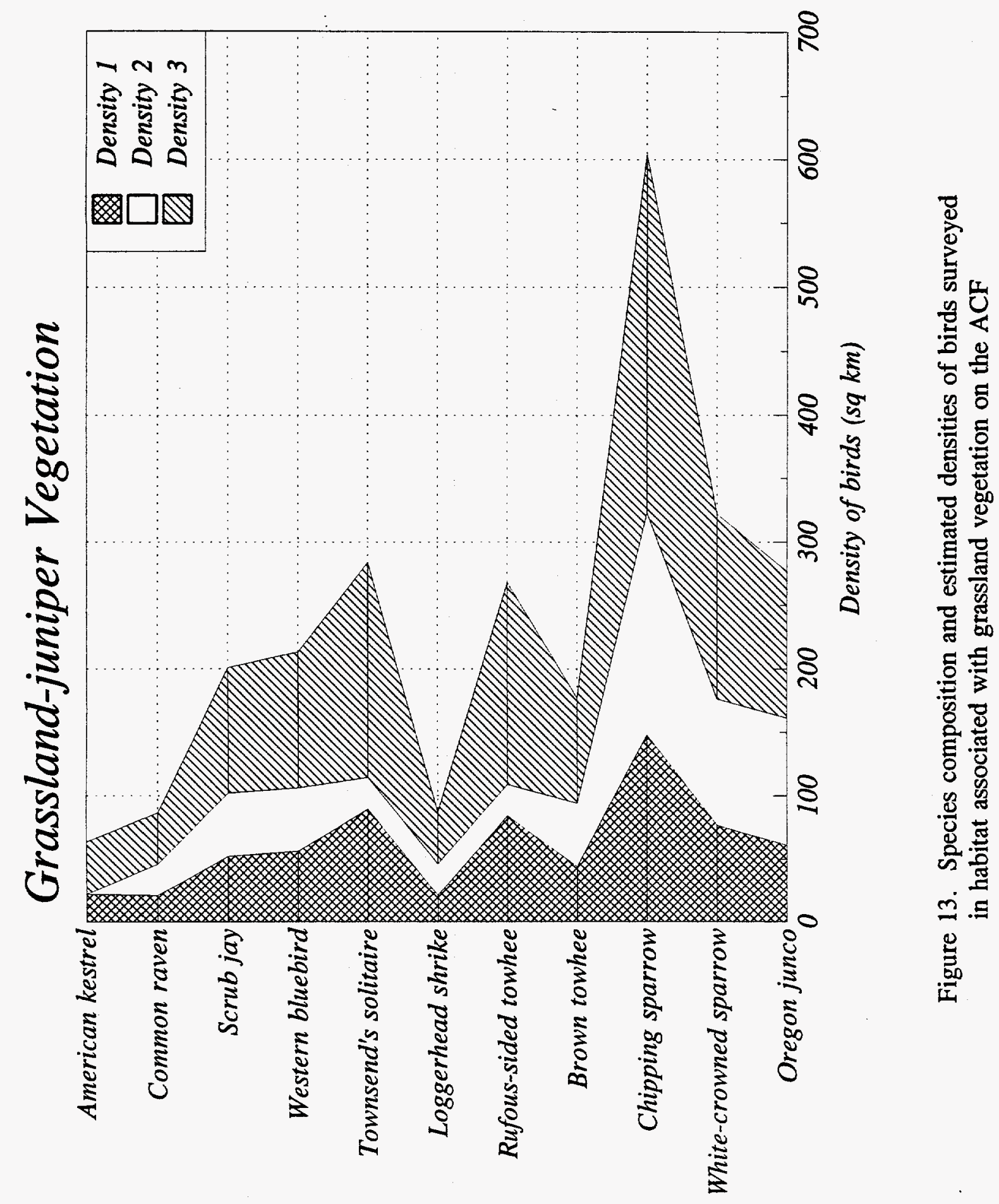




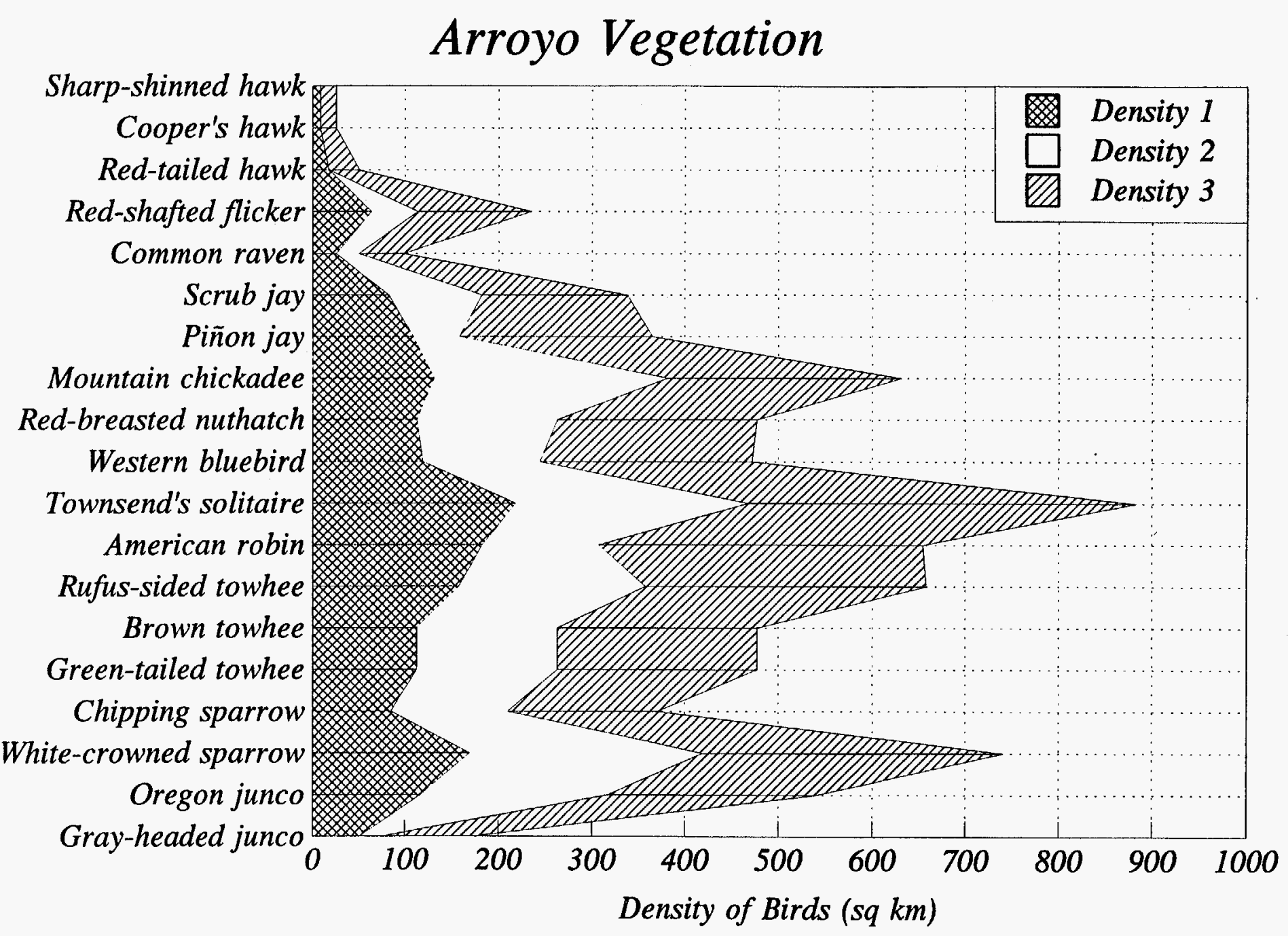

Figure 14. Species composition and estimated densities of birds surveyed in habitat associated with arroyo vegetation on the ACF 


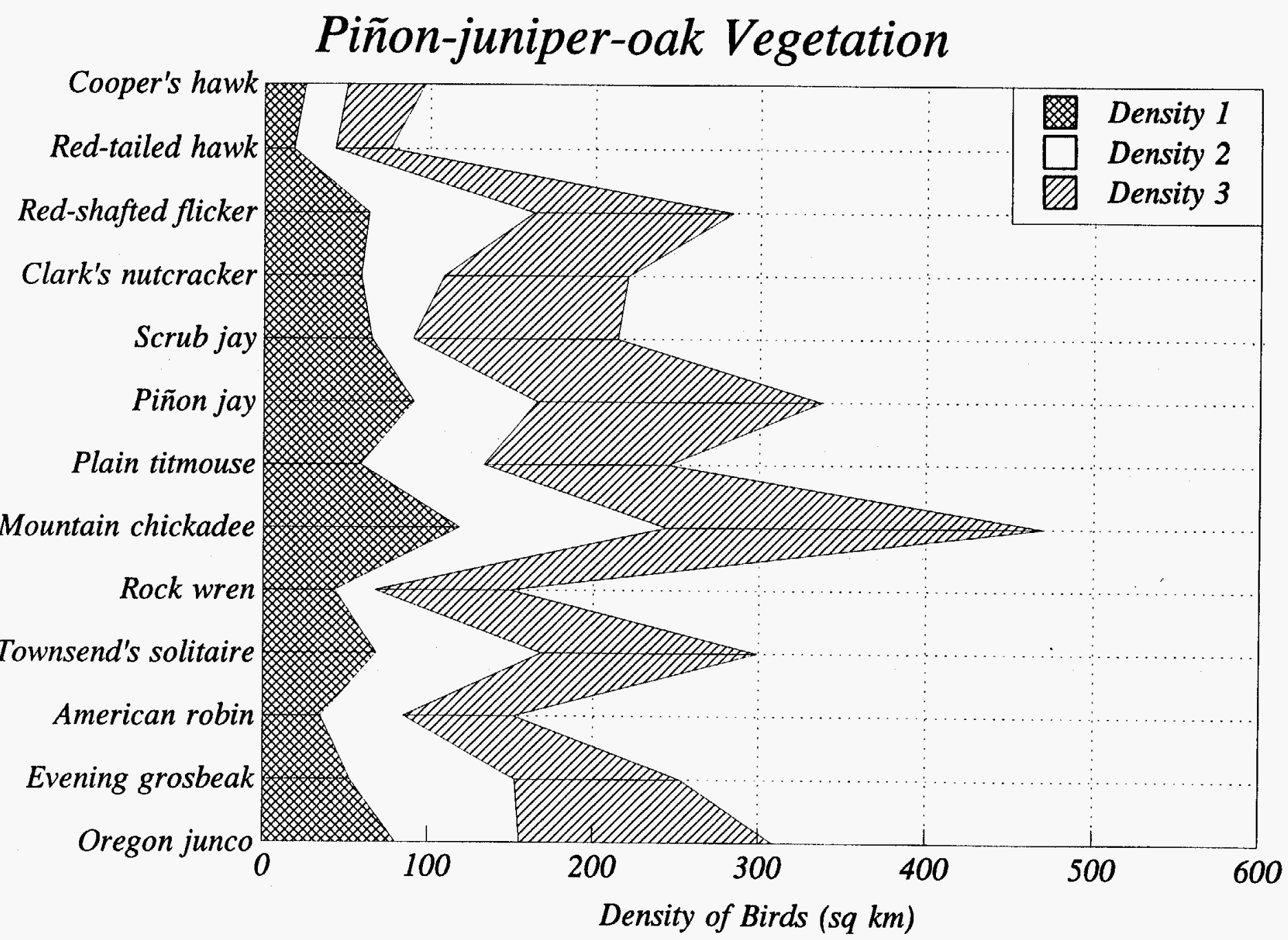

$\infty$
2
0
0
5
5
8

Density of Birds (sq km)

Figure 15. Species composition and estimated densities of birds surveyed in habitat associated with piñon-juniper-oak vegetation on the ACF 
In late September, one golden eagle (Aquila chrysaetos) was observed in grassland-juniper habitat along the north side of Lurance Canyon Road, one mile west of the Explosive Assembly Building. This species was observed feeding in the vicinity of the arroyo. After securing terrestrial prey, the golden eagle flew northeast in the direction of Burn Site. All raptors are protected by the State of New Mexico. In addition, the golden eagle is a fully Federally protected species under Public Law 93-205 and TITLE 16 UNITED STATES CODE, SUBCHAPTER II-PROTECTION OF BALD AND GOLDEN EAGLES Part 668a (16 USC §668a), which designated the bald eagle and the golden eagle as Threatened or Endangered species.

\subsection{MAMMALS}

A variety of mammals were particularly active in the vicinity of rock outcrops (mule deer, Colorado chipmunk, rock squirrel, white-throated woodrat, rock and deer mice, striped skunk, coyote), various drainages (black bear, striped skunk, gray fox, coyote, bobcat, mule deer, rock mouse, deer mouse), and the ecotone between grassland-juniper and piñon pinejuniper woodland (coyote, mule deer, rock squirrel, deer and brush mice, harvest mouse, white-throated woodrat, desert cottontail, valley pocket gopher, kangaroo rat, pocket mouse; Appendices $\mathrm{E}$ and F).

The Colorado chipmunk (Eutamias quadrivittatus quadrivittatus) was commonly observed in the vicinity of rock outcrops and ledges $(\underline{N}=27)$, and individuals were frequently observed drinking free water from Sol se Mete Spring (pers. obs. and photograph). This particular northern subspecies of the Colorado Chipmunk is genetically and morphologically distinct from relict populations of the Threatened and Endangered (Group 2) Oscura Mountain subspecies (E. q. oscura) and the Organ Mountain subspecies (E.q. australis) of the Colorado chipmunk, which occur to the south of the Manzano Mountains in New Mexico (Patterson, 1980; Sullivan, 1994). 
Biggs (1991:14), however, did not observe the Colorado chipmunk in his survey of the SNL Burn Site on KAFB, which included much of the area associated with ACF. Instead, Biggs (1991:14) reported the presence of the least chipmunk ( $E$. minimus) - a species that has never been collected or observed in the Manzano mountains (Findley, et al., 1975; Sullivan, 1985; Sullivan and Petersen, 1988; and the present study). The nearest northern population of least chipmunks (E. $m$. operarius) is isolated on top of the Sandia Mountains, and inhabits sprucefir forest and associated limestone ledges; it is most abundant along the west escarpment of Sandia Crest, above about 2,743.2 meters (9,000 feet) (Sullivan, 1985).

The nearest southern population of the least chipmunk occurs on Sierra Blanca Peak in the Sacramento Mountains of New Mexico (Conley, 1970; Findley, et al., 1975; Sullivan, 1985). This isolate population ( $E$. m. atristriatus) is listed as an Endangered (Group 1) species. If an additional relict population of the least chipmunk did occur in the Manzano Mountains, this finding would be highly significant. It is more parsimonious to assume, however, that Biggs (1991) observed a Colorado chipmunk and not a least chipmunk-the former species is very common in the biological study area. The Colorado chipmunk and the least chipmunk are very difficult to tell apart in the field, because both species are similar in size, and pelage characteristics are quite convergent.

A trapline, consisting of 300 Sherman livetraps spaced 4.5 meters (15 feet) apart, was set in the grassland-juniper habitat that extends from the Winch Site northeast to the vicinity of the abandoned ranch house (Figure 7). Trapping was conducted over a three-day period during the first week of October 1991. Traps were set in the evening and checked the following morning; they were baited with rolled oats. Results are based on 300 "trap nights" of livetrapping, which resulted in the capture of 66 individual small mammals representing eight different species. These data resulted in a 21 percent trap success over the trapping interval, which is a reasonably high estimate. The following species of small mammals were collected in this trapline: $\underline{N}=27$ (40.9 percent) deer mice, $\underline{N}=7$ (10.6 percent) piñon mice, $\underline{N}=4$ (6.1 percent) harvest mice, $\underline{N}=5$ (7.6 percent) grasshopper mice, $\underline{N}=6(9.0$ percent $)$ 
white-throated woodrats, $\underline{N}=11$ (16.7 percent) silky pocket mice, $\underline{N}=4$ (6.1 percent) Ord's kangaroo rats, and $\underline{N}=2$ (3.0 percent) Merriam's kangaroo rats (Appendix $E$ ).

Additionally, numerous fresh burrows with tail tracks were observed in this area, suggesting that densities of mice are rather high in the ungrazed grasslands associated with the biological study area. Deer mice, piñon mice, and woodrats also were commonly observed in abandoned military vehicles (tanks, howitzers) and in the abandoned ranch house (Figure 7). These small mammals also were observed nesting in the scattered furniture and other junk that littered the landscape around the abandoned ranch house (Figure 7), including an adult female deer mouse and six naked, pink young that were found in the drawer of a desk in the field beside the ranch house on 12 October 1991.

Except for mice, rock squirrels were the most abundant species $(\underline{N}=41$ individuals observed) of small, diurnal mammals observed in the biological study area. They were particularly common around the large boulder piles and ledges at the east end of the Rocket Sled, at the west side of Sol se Mete Canyon across from Ground Zero, around equipment and materials stored near the South Arena, and along the lower more arid and rocky south-facing slope of Sol se Mete Spring Canyon. In each of these areas, adults and large numbers of young of the year ( $\underline{N}=4-7$ young per site) were observed, indicating good reproduction by this species.

Black bear, bobcat, coyote, mule deer, and fox tracks or scat were found throughout much of the area associated with the foothills, along arroyos, and adjacent to the unimproved dirt road providing access to Sol se Mete Spring. Drainages and adjacent low-land slopes associated with grassland-juniper habitat and arroyo vegetation function as important travel corridors, bedding sites, and foraging areas for many of the larger species of mammals in the biological study area, particularly in areas that are not disturbed by human activity.

Mule deer sign was also common along virtually all slopes and ridgetops in the biological study area, where mule deer browse on saltbush, mountain mahogany, Apache plume, 
winterfat, and squawbrush. Additionally, cover provided by vegetation in these areas contributes to the well-being of mule deer by providing shelter, increasing their chances of escape from predators, and fostering a sense of security - a number of studies indicate that the latter factor may be highly significant in maintaining mule deer in good physical condition (Dasmann, 1971). Cover must alleviate to tolerable limits the cold, wetness, and snow depths of winter, heat and insect annoyance of summer, and harassment by predators and humans.

The biological unit (territory occupied by an individual mule deer herd) for mule deer over much of its range in New Mexico consists of a winter range, or a group of related winter ranges, and their complementary spring, summer, and fall ranges where the majority of the animals that use the winter range spend the balance of the year. Ungrazed grassland-juniper vegetation associated with the foothills surrounding the biological study area is an important winter range for mule deer (Biggs, 1991). In the biological study area, the winter range occupies a more limited area than the summer range-animals that wander over several thousand acres in the warmer months usually concentrate in a much smaller territory because of unfavorable conditions during the winter. Because home ranges of mule deer must offer food, water, and cover, any additional disturbances (particularly to the winter range) that create fewer close combinations of these three essential elements will tend to decrease mule deer numbers in the general area.

\subsection{AMPHIBIANS AND REPTILES}

Because of the lack of ponds, streams, and other moist habitats, the number of amphibian species is expected to be low in the biological study area. Sol se Mete Spring is the only perennial source of water in the biological study area; however, water from the spring drains from a pipe into a three-foot high brick tank that is not accessible to most ground dwelling amphibians. Only small amounts of rain water fills each of the metal wildlife drinker tanks. These tanks appear to provide some aquatic environment for tadpoles of the red-spotted toad or possibly the western spadefoot toad (Dr. Norman J. Scott, U.S. Department of Interior, 
Fish and Wildlife Service, University of New Mexico, Department of Biology; pers. comm.), because live tadpoles were observed in the wildlife drinker tank nearest to Sol se Mete Canyon during the first week of October. Several species of amphibians that may potentially occur in temporary rain pools in the biological study area include the tiger salamander, woodhouse toad, plains spadefoot toad, western spadefoot toad, and red-spotted toad (Appendices E and F; Fischer, 1990; Biggs, 1991). 
This page intentionally left blank. 


\subsection{PROTECTED SPECIES - PLANTS}

No threatened, endangered, or sensitive species of plants were found in the ACF area. However, the ACF area has the potential to support a large number of plant species. Based upon biological field surveys of habitats within the ACF area, and after consultation with the USFS, U.S. Fish and Wildlife Service (USFWS), and the New Mexico Forestry Division (NMFD), three species lists of plants were compiled. These lists include: (1) a list of all plant species observed within the ACF area (Appendix A); (2) a list of all plant species potentially occurring within the ACF area (Appendix B); and (3) a list of threatened, endangered, or sensitive species of plants potentially occurring within the ACF area (Appendix C). Additionally, Appendix D provides a review of criteria for listing plant species of special concern in State of New Mexico and Federal resource agencies. 
This page intentionally left blank. 


\subsection{PROTECTED SPECIES - ANIMALS}

The ACF area has the potential to support a large number of animal species. Based upon biological field surveys of habitats within the ACF area, and after consultation with the USFS, USFWS, and the New Mexico Department of Game and Fish (NMDGF), a list of animal species occurring and potentially occurring within the ACF area was compiled (Appendices $\mathrm{E}$ and $\mathrm{F}$ ). Information on threatened, endangered, or sensitive animal species that potentially may occur within the ACF area also was compiled (Appendix G). Additionally, Appendix $\mathrm{H}$ provides a review of criteria for listing animal species of special concern in the State of New Mexico and Federal resource agencies.

\subsection{COOPER'S HAWK}

The Cooper's hawk (Accipiter cooperii) is neither a Federal nor State of New Mexico Endangered or Sensitive species; however, all raptors are fully protected by the State of New Mexico. Range of this species is subtropical and temperate North America. It breeds north to, but does not enter the boreal forest of Canada, and south to, but not into, the truly tropical forest. Only in the northernmost part of its range is the Cooper's hawk migratory. This species is a common inhabitant of mesic Southwest woodlands and mixed conifer forest. Although primarily a woodland species that seldom leaves the shelter of trees, it nevertheless shows a strong preference for landscapes where woodlands occur in patches and groves rather than in continuous stands.

On ACF, this kind of habitat is only found along the upper elevations of the Manzano Mountains east of the Upper Anchor, and in coniferous forest habitat. Over much of the species range in the United States, it occupies many areas most heavily used and populated by man. Food of Cooper's hawks consists almost entirely of birds. Prey taken varies in size from chickadees and kinglets up to, occasionally, pheasants or mallards. Because the range of the Cooper's hawk coincides so exactly with the areas of the North American Continent most suitable for human occupance, the species is generally considered to be "common." 
Six Cooper's hawks were observed in mesic woodland and mixed conifer forest habitat along the canyon leading to Sol se Mete Spring. Sensitivity of this species is considered to be low because: (1) this species is restricted in the ACF area to Sol se Mete Spring-an area that supports this species major food source (passerine birds), (2) there is only a small amount of habitat characteristic of this species in the immediate ACF area, and (3) the Sol se Mete Spring area is not used or impacted by ACF operations or personnel.

\subsection{SHARP-SHINNED HAWK}

The sharp-shinned hawk (Accipiter striatus) is neither a Federal nor State of New Mexico Endangered or Sensitive species; however, all raptors are fully protected by the State of New Mexico. This species is the smallest North American accipiter, occurring primarily in northern mountains and forests but is widespread, particularly in winter. Sharp-shinned hawks prefer forest habitat, especially when nesting, and usually hunt from an inconspicuous perch in wooded areas for small birds, almost its only prey. They also hunt by coursing over or through wooded areas and along forest/grassland and woodland/grassland ecotones.

Two sharp-shinned hawks were observed in mesic woodland and mixed conifer forest habitat along the canyon leading to Sol se Mete Spring. Sensitivity of this species is considered to be low because: (1) only a small number of this species was observed in the ACF area, (2) there is only a small amount of habitat characteristic of this species in the immediate ACF area, and (3) the Sol se Mete Spring area is not used or impacted by ACF operations or personnel.

\subsection{RED-TAILED HAWK}

The red-tailed hawk (Buteo jamaicensis) is neither a Federal nor State of New Mexico Endangered, or Sensitive species; however, all raptors are fully protected by the State of New Mexico. This species is the most common and wide spread Buteo in North America. Red-tailed hawks are birds of both open and wooded areas, particularly wooded edges, and 
are often seen perched conspicuously on a treetop, a telephone pole, or other lookouts while hunting. Red-tailed hawks prey mainly on rodents but also on insects and their larvae, fish, and larger mammals, such as rabbits and squirrels. They often pursue prey into dense brush, pirate prey from other raptors, and eat carrion.

Red-tailed hawks were observed soaring over the ACF biological study area, particularly along the grassland and piñon pine-juniper ecotone adjacent to Lurance Canyon Road. Sensitivity of this species is considered to be low because: (1) this species is wide-ranging and relatively abundant in the Manzano Mountain foothills, (2) characteristic habitat for this species is likewise relatively common throughout the area, and (3) ACF activities historically do not appear to have adversely effected the species biology or ecology.

\subsection{NORTHERN HARRIER}

The northern harrier or marsh hawk (Circus cyaneous) has no Federal status, but is a State of New Mexico protected raptor that inhabits plains, fields, open spaces, grasslands, woodlands, and riparian areas. This species nests on the ground in dense cover, or occasionally in deeper, more bulky nests built in shallow water. The northern harrier preys on a variety of animals and regularly detects prey solely by means of its keen hearing.

This species was most commonly observed during the quiet, early morning hours gliding or hovering at low altitude along the ecotone between grassland and piñon pine-juniper vegetation along Lurance Canyon Road. It is also common in the CCTC biological study area, particularly the North and South Thunder Range (Sullivan and Knight, SAND93-7089, 1994).

Seven birds were observed during the survey. Sensitivity of this species is considered to be low because: (1) this species is wide-ranging and relatively abundant in the Manzano Mountain foothills and grassland habitats, (2) characteristic habitat for this species is likewise 
relatively common, and (3) ACF activities historically do not appear to have adversely effected the species biology or ecology.

\subsection{AMERICAN KESTREL}

The American kestrel (Falco sparverius) is neither a Federal nor State of New Mexico Endangered, or Sensitive species; however, all raptors are fully protected by the State of New Mexico. The widespread American kestrel is the smallest North American falcon and one of the most common. This species is usually seen hovering or sitting on exposed perches, such as poles, fence lines, wires, or treetops, where it hunts for rodents, insects, birds, lizards, or snakes. Kestrels nest in tree cavities but will readily use holes in cliffs and crevices in buildings, as well as nest boxes. This species is a common inhabitant of the southwest and relatively arid grassland regions of New Mexico, including plains, open spaces, deserts, woodlands, and riparian habitats.

This species is locally abundant in the ACF biological study area, particularly along the ecotone between grassland and piñon pine-juniper habitat along Lurance Canyon.

A total of 23 birds was observed during the survey. Sensitivity of this species is considered to be low because: (1) this species is wide-ranging and abundant in the Manzano Mountain foothills and grassland habitats, (2) characteristic habitat for this species is likewise relatively common, and (3) ACF activities historically do not appear to have adversely effected the species biology or ecology. 


\subsection{LOGGERHEAD SHRIKE}

The loggerhead shrike (Lanius ludovicianus) is a Federal Category 2 Candidate species whose status is classified as unknown (U), indicating that additional survey work is required to determine its current distribution, abundance and population trends; the loggerhead shrike has no State of New Mexico status. This species inhabits open spaces, grasslands, deserts, woodlands, and riparian areas.

Loggerhead shrikes were commonly observed in the Lurance Canyon area and in the immediate vicinity of ACF, particularly along the main dirt road and in tall road-side vegetation. In addition, individuals commonly perch-hunt from barbed-wire fences that overlook the grassland habitat within ACF.

Fifteen birds were observed during the survey. Sensitivity of this species is considered to be low because: (1) this species is wide-ranging and abundant in the Manzano Mountain foothills and grassland habitats, (2) characteristic habitat for this species is likewise relatively common, and (3) ACF activities historically do not appear to have adversely effected the species biology or ecology.

\subsection{GRAY VIREO}

The gray vireo (Vireo vicinior) is a State of New Mexico Endangered Group 2 species with no Federal status that summers from southern California to western Oklahoma, southern New Mexico, western Texas, and northern Coahuila, Mexico. In New Mexico this species summers locally west of the eastern plains, from San Juan Valley, Santa Fe area, Montoya (Quay Co.), southward to Mexico (Handbook of Species Endangered in New Mexico, 1990). Key habitat areas likely include the San Juan Valley below Navajo Lake, the Glenwood area (Catron Co.), Guadalupe Canyon (Hidalgo Co.), and the southern end of the Guadalupe Mountains. The gray vireo is known to occur infrequently in areas surrounding Bernalillo County and the ACF area, including Cibola, McKinley, Socorro, and Santa Fe Counties. 
Breeding habitat of this species is generally open woodlands and shrublands; junipers are the dominant evergreen in most areas of its occurrence in New Mexico (Handbook of Species Endangered in New Mexico, 1990). This species generally occurs in New Mexico only in the warmer months of April through September (Handbook of Species Endangered in New Mexico, 1990; Montoya, 1990) and is relatively common in parts of its range. Recent data from New Mexico suggest that the gray vireo may warrant delisting because it appears to be more numerous than previously thought (Montoya, 1990).

This species was observed in the ACF area. One gray vireo was observed on two consecutive days (3-4 October, 1991) in piñon pine-juniper woodland near the lower drinker tank located at the entrance to the canyon leading to Sol se Mete Spring, and probably represented by one migrating individual. Sensitivity of this species is considered to be low because: (1) only one "migratory or transient" individual was observed, (2) there is only a small amount of habitat characteristic of this species in the immediate ACF area of operations, and (3) the Sol se Mete Spring area is not used or impacted by ACF operations or personnel.

\subsection{TEXAS HORNED LIZARD}

The Texas horned lizard (Phrynosoma cornutum) is a Federal Candidate 2 species. Currently, this species has no State of New Mexico status; however, all species of horned lizards are protected in New Mexico, and specific permits are required from the NMDGF to collect these lizards. The Texas horned lizard is common in desert areas throughout southern and central New Mexico. These horned lizards live in shrubland, desert grassland, and associated juniper woodland. They feed mostly on ants, and occur in areas where ants, particularly seed harvester ants belonging to the genus Pogonomyrmex, are abundant.

Two $P$. cornutum were observed in the large expanse of grassland-juniper habitat near the intersection of Lurance and Sol se Mete Canyons. Sensitivity of this species is considered to be low because: (1) although only two individuals were observed during the survey 
grassland habitat for this species is abundant west and northwest of the ACF area and, (2) no evidence of mortality was observed along the main roadway leading to the site (i.e., Lurance Canyon and Sol se Mete Canyon roads).

\subsection{SHORT-HORNED LIZARD}

The short-horned lizard (Phrynosoma douglassi) has no Federal status. Currently, this species also has no State of New Mexico status; however, all species of horned lizards are protected in New Mexico, and specific permits are required from the NMDGF to collect these lizards. The short-horned lizard is common in desert areas throughout southern and central New Mexico. These horned lizards live in shrubland, desert grassland, and associated juniper woodland. They feed mostly on ants, and occur in areas where ants, particularly seed harvester ants belonging to the genus Pogonomyrmex, are abundant.

Short-horned lizards were observed, but they are not common in grassland habitat associated with ACF. Seven animals were observed during survey. Sensitivity of this species is considered to be low because: (1) low abundance of grassland habitat in ACF area, and (2) no evidence of mortality was observed along the main roadway leading to the site (i.e., Lurance Canyon and Sol se Mete Canyon roads).

\subsection{ROUND-TAILED HORNED LIZARD}

The round-tailed horned lizard (Phrynosoma modestum) has no Federal status. Currently, this species also has no State of New Mexico status; however, all species of horned lizards are protected in New Mexico, and specific permits are required from the NMDGF to collect these lizards. Round-tailed horned lizards are common in desert areas throughout southern and central New Mexico. These horned lizards live in shrubland, desert grassland, and associated juniper woodland. They feed mostly on ants, and occur in areas where ants, particularly seed harvester ants belonging to the genus Pogonomyrmex, are abundant. 
Round-tailed horned lizards were rarely observed on the ACF biological study area. They occurred exclusively in grassland and piñon pine-juniper vegetation adjacent to Lurance Canyon Road. Four animals were observed during the survey. Sensitivity of this species is considered to be low because: (1) grassland habitat for this species is abundant west and northwest of the ACF area, and (2) no evidence of mortality was observed along the main roadway leading to the site (i.e., Lurance Canyon and Sol se Mete Canyon roads). 


\subsection{SENSITIVE HABITAT AREAS}

Within the biological study area, there are a number of potentially sensitive habitat areas used by a variety of animals, including: (1) bedding areas and travel corridors, (2) foraging areas, (3) raptor use areas, and (4) watering areas.

\subsection{BEDDING AREAS AND TRAVEL CORRIDORS FOR MAMMALS}

Mule deer, their tracks, and scat were observed throughout the biological study area; however, the heaviest concentration of mule deer sign was evident along the ecotone between the grassland-juniper and woodland habitat associated with both sides of Sol se Mete Canyon north of the North Arena, and in Sol se Mete Spring Canyon, particularly in arroyo vegetation near the wildlife drinker tanks and Sol se Mete Spring. Additionally, mule deer sign also was evident along the grassland-juniper and piñon pine-juniper ecotone extending from the Winch Site to the western edge of the Explosive Assembly Area and parking lot. The boundary between grassland and piñon pine-juniper woodland provides cover and bedding sites that are close to preferred foraging areas associated with grassland-juniper habitat and the high shrub diversity found in arroyos along drainages. Major drainages also provide natural travel corridors for mule deer, jackrabbit, and desert cottontail, and their carnivorous predators like the coyote, gray fox, and bobcat.

\subsection{MULE DEER FORAGING AREAS}

Locations of foraging areas were highly correlated with the distribution of bedding areas and travel corridors, as evidenced by tracks, feces, and bedding sites. Foraging areas for mule deer were consistently associated with the ecotone between grassland, piñon pine-juniper woodland, and shrubby arroyo vegetation. These areas provide the largest diversity of vegetation for browsers and other herbivorous species of wildlife, and provide winter range for mule deer. Mule deer browse shrubby species such as Gambel oak, New Mexico locust, 
scrub live-oak, mountain mahogany, Apache plume, four-wing saltbush, and winter-fat; which are found in abundance in the foothills and along major low-lying drainages.

\subsection{RAPTOR USE AREAS}

Several species of raptors were observed during the biological field survey, including golden eagle $(\underline{N}=1)$, red-tailed hawk $(\underline{N}=6)$, Cooper's hawk $(\underline{N}=6)$, sharp-shinned hawk $(\underline{N}=2)$, and American kestrel $(\underline{N}=5)$.

In late September, one golden eagle was observed in grassland-juniper habitat along the north side of Lurance Canyon Road, $1.6 \mathrm{~km}$ (1 mile) west of the Explosive Assembly Building. This species was observed feeding in the vicinity of the arroyo. After securing terrestrial prey, the golden eagle flew northeast in the direction of Burn Site. Canyons, drainages, and other open areas located at the head of Lurance Canyon and Madera Canyon could potentially provide nest sites that would be suitable for use by golden eagles and other large raptors.

All of the red-tailed hawks and American kestrels observed in the biological study area were associated with the grassland-juniper habitat, or the ecotone between grassland and piñon pine-juniper woodland along Sol se Mete Canyon, and between this canyon and the Winch Site. Large junipers within the grassland vegetation and large piñon pine at the woodland edge provide observation and perching sites for red-tailed hawks that prey on the abundance of small mammals associated with the grassland-juniper and shrubby vegetation of the arroyos. American kestrels were also found in association with this habitat and the electric power-lines along Lurance Canyon Road where they perch and feed on insects and small vertebrates found in grassland vegetation.

All sightings of Cooper's and sharp-shinned hawks were made within the arroyo vegetation and piñon pine-juniper woodland found within Sol se Mete Spring Canyon, or in the upper regions of the East Anchor Access Road lying within ponderosa pine and piñon pine-juniper- 
oak woodland vegetation (less than $2,316.5$ meters; 7,600 feet elevation). Wooded habitat providing abundant cover, nesting and perching sites, a perennial source of free water, and the large prey-base of perching birds found in Sol se Mete Canyon all provide an ideal habitat for these two species of small bird-eating hawks.

\subsection{WATER SOURCES}

Coyote Springs, the Burn Site Spring, and Sol se Mete Spring provide the only perennial sources of free water found near or within the biological study area. Sol se Mete Spring is the only source of free water on the ACF biological study area. These natural springs have been partially developed, but provide virtually negligible natural wetland habitat. However, they are significant sources of free water to local species of wildlife in the surrounding area, particularly larger mammals (deer, coyote, fox) and raptors (hawks, owls, and golden eagle).

\subsubsection{Sol se Mete Spring}

During the survey period (mid-September-November 1991) there was abundant fresh, running water in Sol se Mete Spring (Figure 12), and in each of the three wildlife drinker tanks below the spring in Sol se Mete Canyon. Sol se Mete Spring provides the only abundant, perennial, and uncontaminated free water in the area. This spring is used heavily by all wildlife species, including mule deer, bear, coyote, gray fox, bobcat, raccoons, skunks, passerine and nonpasserine birds, and raptors. During one morning hour (0700-0800) the biological survey team counted 90 individual birds (11 species; eight of which were photographed) watering at this spring. As many as six species of birds watered at the spring simultaneously. The species of birds included 5 robins, 6 plain titmice, 3 red-shafted flickers, 3 Steller jays, 20 gray-headed juncos, 14 Oregon juncos, 12 red-breasted nuthatches, 12 chickadees, 5 rufous-sided towhees, 8 kinglets, and 2 acorn woodpeckers.

Although use of drinker tanks by wildlife in the canyon below Sol se Mete Spring was observed (visual observation of animals and animal tracks), this use was not as heavy as at 
Sol se Mete Spring. During October and November, the three drinker tanks below Sol se Mete Spring contained small amounts of stagnant water.

Upper reaches of Sol se Mete Canyon and Sol se Mete Spring lie in a relatively narrow drainage basin. Sol se Mete Canyon has a distinct east-west orientation. The north-facing canyon walls provide a cool, mesic northern exposure conducive for wildlife. The southfacing (southern exposure) canyon walls of Sol se Mete Canyon where the drinkers are located have a more arid southern exposure to the drainage basin. Perennial sources of water, plant assemblages associated with both a northern and southern exposure, nearby arroyo vegetation, and an obvious lack of human disturbance combine to optimally maximize an ecological setting that facilitates the greatest diversity and density of wildlife species in the biological study area. Use of the drinker tank located along the more expansive and arid southeast fork of Lurance Canyon (near the Burn Site) was much less obvious.

\subsubsection{Ephemeral Water Sources}

There are no significant areas of open water in the ACF area; however, there are four major drainages that receive runoff and have small, natural, but ephemeral water catchments, including: (1) the upper regions of Lurance and Coyote Canyons and their associated arroyos; (2) Sol se Mete Canyon proper that runs through the entire length of the major biological study area and has a north-south drainage basin orientation; (3) the arroyo associated with Sol se Mete Spring that has an east-west orientation; and (4), the north-south running arroyo associated with the West $\mathrm{ACF}$ and Winch Sites.

These drainages receive the largest amounts of use by wildlife following precipitation periods, and presumably snow melt, and in many of these drainages various shrubs and trees provide cover and perching substrates for a variety of passerine birds. In addition, these areas are particularly important to many of the more common raptors known to occur in the vicinity that may rely significantly on the nearby ACF and CCTC areas (Sullivan and Knight, SAND93-7089, 1994) for obtaining prey (i.e., golden eagle, northern harrier, 
red-tailed hawk, Swainson's hawk, ferruginous hawk, American kestrel, peregrine falcon). In these drainages, water will remain for longer periods of time if shrubs and trees remain undisturbed because they provide shading, thus increasing the quality of these canyons as wildlife habitat. 
This page intentionally left blank. 


\subsection{REFERENCES}

A Handbook of Rare and Endemic Plants of New Mexico. 1984. New Mexico Native Plants Protection Advisory Committee. University of New Mexico Press, Albuquerque. 291 pp.

Handbook of Species Endangered in New Mexico. 1990. New Mexico Department of Game and Fish, Santa Fe, New Mexico. 291 pp.

Aldous, S.E. 1940. Notes on a Black-footed Ferret Raised in Captivity. Journal of Mammalogy, 21:23-26.

Bailey, V. 1931. Mammals from New Mexico. U.S. Department of Agriculture, Bull. Biological Survey, North American Fauna, 53:1-412.

Bickel, D. C. 1993. Personnel communication. August, 1993.

Biggs, J. 1991. Sensitive Species Survey for Sandia National Laboratories Burn Site, Kirtland Air Force Base, New Mexico. Chambers Group, Inc., Santa Ana, California.

Brower, J., J. Zar, and C. von Ende. 1989. Field and Laboratory Methods for General Ecology. Wm. C. Brown Publishers, Dubuque, IA.

Brown, D.E. and C.H. Lowe. 1982. Map: Biotic Communities of the Southwest. Publication Distribution, Rocky Mountain Forest and Range Experiment Station. U.S.D.A. Forest Service, Fort Collins, Colorado.

Caughley, G. 1977. Analysis of Vertebrate Populations. John Wiley \& Sons, New York.

Conley, W.H. 1970. Geographic Variation in the Least Chipmunk Eutamias minimus in New Mexico and Eastern Arizona. Journal of Mammalogy, 51:695-702.

Dasmann, W. 1971. If Deer Are to Survive. Stackpole Books, Harrisburg, PA.

Easterla, D.A. 1965. The Spotted Bat in Utah. Journal of Mammalogy, 46:665-668.

Easterla, D.A. 1973. Ecology of the 18 Species of Chiroptera at Big Bend National Park Texas. Northwest Missouri State University Studies 33.

Eberhardt, L.L. 1968. A Preliminary Appraisal of Line Transects. Journal of Wildlife Management, 32:82-88.

Fenton, M.D., D.C. Tennant, and J. Wyszecki. 1983. A Survey of the Distribution of Euderma maculatum (Chiroptera: Vespertilionidae) Through its Known Range in the United States and Canada by Monitoring its Audible Echolocation Calls. U.S. Fish and Wildlife Service, Contract 14-16-0002-82-210, Final Report:1-44. 
Fenton, M.D., D.C. Tennant, and J. Wyszecki. 1987. Using Echolocation Calls to Measure the Distribution of Bats: the Case of Euderma maculatum. Journal of Mammalogy, 69:142-144.

Findley, J.S. 1987. The Natural History of New Mexican Mammals. University of New Mexico Press, Albuquerque.

Findley, J.S., A.H. Harris, D.E. Wilson, and C. Jones. 1975. Mammals of New Mexico. University of New Mexico Press, Albuquerque, $360 \mathrm{pp}$.

Fischer, T.N. 1990. SAND90-7089 Contractor Report. Revision of Species Inventory Checklists for Sandia National Laboratories, Albuquerque, Bernalillo County, New Mexico. National Technical Information Service, U.S. Dept. of Commerce; Springfield, Virginia.

Hoffmeister, D.F. 1986. Mammals of Arizona. University of Arizona Press, Tucson.

Hoglund, N., G. Nilsson, and F. Stalfelt. 1967. Analysis of a Technique for Estimating Willow Grouse (Lagopus) Density. Transactions of the 8th International Congress of Game Biologists, 156-159.

Hohnstreiter, G.F., W.L. Uncapher, D.C. Bickel, M.S. Garrett, N.R. Kellner, and D.R. Schafer. 1991. Test Facilities for Radioactive Materials Transport Packages (Sandia National Laboratories, USA). Ramtrans 2:81-89.

Hillman, C.N., and T.W. Clark. 1980. Mammalian Species No. 126, pp. 1-3, 3 figs.

Hubbard, J.P. 1987. The Status of the Willow Flycatcher in New Mexico. New Mexico Department of Game and Fish, Endangered Species Program, draft report:1-29.

Knight, Paul J., 1994. Personal communication. April 24, 1994.

Martin, W.C. and W.L. Wagner. 1974. Survey of Kirtland Air Force Base (East), SAND74-0393, Sandia National Laboratories. Albuquerque, New Mexico.

Montoya, B. 1990. Revision of the List of Endangered Species. New Mexico Department of Game and Fish, 13 April 1990. 7pp.

New Mexico Department of Game and Fish. 1992. Recommendations for Wildlife Baseline Study Guidelines for Construction Projects. 11pp.

Nichol, A.A. 1938. Experimental Feeding of Deer. University of Arizona Technical Bulletin No. 75. 
Patterson, B.D. 1980. A New Species of Eutamias quadrivittatus (Rodentia: Sciuridae from the Organ Mountains, New Mexico. Journal of Mammalogy, 16:455-464.

Ross, A. 1961. Notes on Food Habits of Bats. Journal of Mammalogy 65:122-126.

Scott, Dr. Norman J., 1991. U.S. Department of Interior, Fish and Wildlife Service, University of New Mexico, Department of Biology. Personal communication. 1991.

Sivinski, R., and K. Lightfoot. 1992. Inventory of Rare and Endangered Plants of New Mexico. New Mexico Forestry Division and Resources Conservation Division Energy, Minerals, and Natural Resources Department State Forester. 58pp.

Skaggs, R.W. 1990. Results of a Cliff-nesting Raptor Survey on White Sands Missile Range. Appended to Biological Assessment. Special Technical Report 2, prepared for Aerial Cable Test Capability Environmental Impact Statement. Physical Science Laboratory Doc. PSL-90/101.

Smith, R.L. 1980. Ecology and Field Biology. Harper and Row, New York.

Sullivan, R.M. 1985. Phyletic, Biogeographic, and Ecologic Relationships among Montane Populations of Least Chipmunks (Eutamias minimus) in the Southwest. Systematic Zoology, 43:419-448.

Sullivan, R.M., and K.E. Petersen. 1988. Systematics of Southwestern Populations of Least Chipmunks (Tamias minimus) Reexamined: a Synthetic Approach. Occasional Papers of the Museum of Southwestern Biology, University of New Mexico, 5:1-27.

Sullivan, R.M. 1994. Genetics, Ecology, and Conservation of Relict Montane Populations of the Colorado Chipmunk (Eutamias quadrivittatus), with a Description of a New Subspecies from the Oscura Mountains, New Mexico. In press, Journal of Mammalogy.

Sullivan, R.M., and P.J. Knight. 1994. Biologic Surveys for the Sandia National Laboratories Coyote Canyon Test Complex Kirtland Air Force Base, Albuquerque, New Mexico. Contractor Report SAND93-7089.

Unitt, P. 1987. Empidonax traillii extimus: and Endangered Subspecies. Western Birds, $18: 137-162$.

Weniger, D. 1988. A Field Guide Cacti of Texas and Neighboring States. University of Texas Press, Austin, 356 pp. 
This page intentionally left blank. 


\subsection{DISTRIBUTION LIST}

U.S. Department of Energy

Albuquerque Field Office

P.O. Box 5400

Albuquerque, NM 87185

Attn: J.F. Levings, ERPO, AL

C.L. Soden, EPD, AL

2

U.S. Department of Energy

Kirtland Area Office

Albuquerque, NM 87185

Attn: G.K. Laskar

S. L. Lacy

4

R. Cunniff

Physical Science Laboratory

Environmental Group

P.O. Box 30002

Las Cruces, NM 88003-0002

1

T. Fischer

IT Corporation

5301 Central Ave, NE

Suite 700

Albuquerque, NM 87108

1

Ellen Debruin

New Mexico Natural Heritage Program

University of New Mexico

2500 Yale SE

Albuquerque, NM 87131

1

Jennifer Fowler-Propst, Field Supervisor

U.S. Fish and Wildlife Service

Office of Ecological Services

Suite D, 3530 Pan American Hwy, NE

Albuquerque, NM 87107

Attn: Ann Cully, Endangered Species Biologist

1

Bill Montoya, Director

State of New Mexico

Department of Fish and Game

Villagra Building

P.O. Box25112

Santa Fe, NM 87504

Attn: Robert Jenks 


\section{DISTRIBUTION LIST (Continued)}

Raymond Gallegos, State Forester

State of New Mexico

Energy, Minerals, and Natural Resources Department

Santa Fe, NM 87505

Attn: Karen S. Lightfoot

Reggie A. Fletcher, Regional Ecologist

U.S. Forest Service

517 Gold Avenue SW

Albuquerque, NM 87102

Robert M. Sullivan

4115 Allen Drive

Kingsville, TX78363

MS0100 Document Processing for DOE/OSTI, 7613-2

MS0619 Technical Publications, 13416

MS0899 Technical Library, 13414

MS9018 Central Technical Files, 8523-2

MS1035 J. T. Baremore, 7200

MS1037 A. O. Bendure, 7258

MS1037 J. M. Harris, 7258

MS1037 D. L. Nargelovic, 7258

MS1037 T. Sanchez-Brown, 7258

MS1037 T. A. Wolff, 7258

MS1135 D. C. Bickel, 2735

MS1135 M. S. Garrett, 2761

MS1307 J. B. Halpern, 7572

MS1311 L. J. Shyr, 7575

MS1347 W. Cox, 7581

MS1347 R. E. Fate, 7585 
Appendix A. List of plant species observed in ACF biological study area. Species marked by an * are Threatened, Endangered, Protected, or of Special Concern.

western wheatgrass (Agropyron smithii)

slender wheatgrass (Agropyron trachycaulum)

western ragweed (Ambrosia psilostachya)

three-awn grass (Aristida purperea)

Bigelow sagebrush (Artemisia bigelovii)

aster (Asper spp.)

Nuttal's milkvetch (Astragalus nuttallianus)

four-wing saltbush (Atriplex canescens)

yellow ragweed (Bahia dissecta)

barberry (Berberis spp.)

side-oats grama (Bouteloua curtipendula)

hairy grama (Bouteloua hirsuta)

black grama grass (Bouteloua eriopoda)

blue grama grass (Bouteloua gracilis)

brome (Bromus spp.)

indian paintbrush (Castilleja integra)

hackberry (Celtis reticulata)

mountain mahogany (Cercocarpus montanus)

winterfat (Ceratoides lanata)

fern (Cheilanthes spp.)

rabbitbrush (Chrysothamnus nauseosus)

New Mexico thistle (Cirsium neomexicanum)

pincushion cacti (Coryphantha spp.)

New Mexico pincushion cacti (Coryphantha vivipara)

buffalo gourd (Cucurbita foetidissima)

indian apple (Datura meteloides)

tansy mustard (Descurainia richardsonii)

hedgehog cactus (Echinocereus coccineus)

red-goblet cactus (Echinocereus polyacanthus)

claretcup cactus (Echinocereus triglochidiatus)

mormon tea (Ephedra torreyana)

buckwheat (Eriogonum spp.)

Apache-plume (Fallugia paradoxa)

tarbush (Flourensia cernua)

broom snakeweed (Gutierrezia sarothrea)

camphor weed (Heterotheca spp.)

galleta grass (Hilaria jamesii)

skyrocket (Ipomopsis spp.) 
one-seed juniper (Juniperus monosperma)

Rocky Mountain juniper (Juniperus scopulorum)

summer cypress (Kochia scoparia)

deer vetch (Lotus wrightii)

ring muhly (Muhlenbergia torreyi)

beargrass (Nolina parryi)

daggerthorn cholla (Opuntia clavata) *

tree cholla (Opuntia imbricata)

prickly pear (Opuntia phaeacantha)

indian ricegrass (Oryzopsis hymenoides)

piñon pine (Pinus edulis)

primrose (Primula spp.)

scrub live oak (Quercus turbinella)

Gambel oak (Quercus gambelii)

wax current (Ribes cercum)

New Mexico locust (Robinia neomexicana)

wild rose (Rosa spp.)

squawbrush (Rhus trilobata)

Russian thistle (Salsola kali)

groundsel (Senecio spp.)

horse nettle (Solanum eaeagnifolium)

globemallow (Sphaeralcea spp.)

dropseed grass (Sporobolus spp.)

New Mexico porcupine grass (Stipa neomexicana)

cottontop or cottongrass (Trichachne californica)

soapweed yucca (Yucca glauca)

banana yucca (Yucca bacata) 
Appendix B. List of plant species expected in the biological study area. These species were not observed during the biological surveys. Species marked by an * are Threatened, Endangered, Protected, or of Special Concern.

Santa Fe milkvetch (Astragalus feensis)*

bricklebush (Brickellia spp.)

Fremont's goosefoot (Chenopodium fremontii)

button cactus (Epithelantha micromeris)*

Wright's pincushion cactus (Mammillaria wrightii var. wrightii)*

white-flowered visnagita cactus (Neolloydia intertexta var. dasyacantha)*

dune unicorn plant (Proboscidea sabulosa)*

grama grass cactus (Toumeya or Pediocactus papyracantha) 
This page intentionally left blank. 
Appendix C. Information on State of New Mexico and Federal sensitive species of plants potentially occurring in ACF area. Sources are from Weniger (1988), A Handbook of Rare and Endemic Plants of New Mexico (1984), the 1992 Inventory of Rare and Endangered Plants of New Mexico (R. Sivinski and K. Lightfoot, eds.), New Mexico Forestry Division and Resources Conservation Division Energy, Minerals, and Natural Resources Department State Forester.

\section{Agastache cana}

Status: Federal (none); State of New Mexico Sensitive (R-E-D Code: 1-1-2).

Habitat: Great Basin Conifer Woodland: Cold adapted evergreen woodland at intermediate elevations; short stature trees of piñon and juniper. Dry slopes in piñon pine-juniper woodland from 1,600 to 1,904 meters $(5,250-6,250$ feet).

Sensitivity: Low (not seen during survey; moreover, a record from the nearby Sandia Mountains is questionable; another from the headwaters of the Pecos is also anomalous).

\section{Santa Fe milkvetch (Astragalus feensis)}

Status: Federal (none); State of New Mexico Sensitive (R-E-D Code: 1-1-3).

Habitat: Great Basin Conifer Woodland: Cold adapted evergreen woodland at intermediate elevations; short stature trees of piñon pine and juniper. Dry slopes in piñon pine-juniper woodland from 1524 to 1981 meters $(5,000-6,500$ feet).

Sensitivity: Low (not seen during survey; however, this species was observed in low frequency in the nearby North and South Thunder Ranges of the CCTC (Sullivan and Knight, SAND93-7089, 1994), and probably occurs in the general vicinity of ACF. Additional information: The Santa Fe milkvetch is a herbaceous species with spreading or prostrate stems that often curve upward at the ends. Flowers are pealike, reddish-purple in color, and rarely more than 1.3 to $1.6 \mathrm{~cm}(0.6$ inches) long. It has a conspicuous pod that is three-angled in cross section and is covered with small hairs. It flowers from late March through May. It is endemic in central New Mexico extending from just north of Santa $\mathrm{Fe}$ and southward to Belen. Normally it occurs on dry slopes in grassland or lower piñon pine-juniper woodland between 1,524 and 2,133 meters $(5,000-7,000$ feet) in elevation. It is often found in rocky areas or where coarse gravelly or sandy-gravel soils occur. Santa Fe milkvetch usually occurs in locally abundant populations. Such populations have been identified in several locations in Albuquerque, such as in the foothills of the Sandia Mountains as well as the escarpment on the west side of Ceja Mesa just west of Albuquerque. The plants are not threatened except in areas of severe habitat destruction. As with many species of milkvetch, they tend to be somewhat weedy and will often occupy disturbed ground within their range.

\section{Wright's fishhook cactus (Mammillaria wrightii var. wrightii)}

Status: Federal (none); State of New Mexico Endangered (R-E-D Code: 1-2-2).

Habitat: Great Basin Conifer Woodland: Cold-adapted evergreen woodland at intermediate elevations; short stature trees of piñon pine and juniper. Plains and Great 
Appendix C (Continued)

Basin Grassland: mostly short-grass plains of grama, wheatgrass, threeawn, muhly, galleta, and buffalo grass; dominated by broom snakeweed when continuously grazed by livestock; usually below 2,286 meters $(7,500$ feet) in elevation. Semidesert Grassland: hot, dry, grassy plains, such as black grama, dropseed, tobosa, and burrograss; mesquite; and soaptree yucca.

Sensitivity: Low (not seen during survey, but reported in Lurance Canyon).

Additional Information: Wright's fishhook cactus is a small cactus, usually less than $7.5 \mathrm{~cm}$ ( 3 inches) across, and is somewhat depressed globose in shape. It usually has 10 to 15 straight spines and one or two small hooked spines at the tip of each tubercle. It flowers in August and September supporting large $[2.5-7.5 \mathrm{~cm}$ ( $1-3$ inches) wide] bright purple to magenta flowers. There are several varieties of Wright's fishhook cactus, but $M$. $w$. var. wrightii is the only variety expected within the ACF area (Sullivan and Knight, SAND93-7089, 1994). Wright's fishhook cactus ranges from north-central New Mexico into Texas and westward into Arizona.

Wright's fishhook cactus normally occurs on gravelly or sandy hills or plains ranging from desert grassland to piñon pine-juniper woodland at an elevation from 1,463 to 2,286 meters $(4,800-7,500$ feet). Within the Albuquerque area it has been found in coarse-soiled grama grasslands at the base of the Sandia Mountains, extending southward into the Four Hills Area. It is more likely to occur near the base of the mountains rather than the open sandy bajada that lies below. Numerous individuals of this species occur in the vicinity of the Live Firing Range west of ACF (Biggs, 1991). It is threatened by habitat destruction as well as collection by cactus enthusiasts. The large showy flowers produced by this species make it particularly desirable in the horticultural trade.

\section{Button cactus (Epithelantha micromeris)}

Status: Federal (none); State of New Mexico Endangered (R-E-D Code: 1-2-1).

Habitat: Chihuahuan Desert Scrub: hot, dry plains with widely scattered shrubs typically of creosotebush, tarbush, mesquite, acacia, and yucca with warm-season grasses, forbs, and cacti in shrub interspaces; widespread throughout Southwest, usually at elevations below 1676.4 meters (5,500 feet). Semidesert Grassland: hot, dry plains of warm-season grasses such as black grama, dropseed, tobosa, and burrograss; mesquite; and soaptree yucca. Interior Chaparral: relatively dense shrub association on desert mountain slopes. Diverse composition, with Chihuahuan, Sonoran, and Great Basin desert affinities (i.e., scrub live oak, manzanita, mountain mahogany, silktasses, sotol, catclaw. Lower slopes of mountains in Southwest, exposed ridges, hillsides, river beds, and associated arroyos.

Sensitivity: Low (not present during survey).

Additional Information: The button cactus (Epithelantha micromeris) or mulato occurs in deserts of Mexico, in southern Arizona, in the Trans-Pecos region of Texas, and in southern and central New Mexico. It is a small cactus, barely reaching $4 \mathrm{~cm}$ 
(1.5 inches) in diameter, and densely covered with small white spines. Bright red to carmine flowers are clearly visible in mid-spring. Its microhabitat is small fissures and cracks in the limestone bedrock where it is sheltered and harvests runoff moisture from the surrounding rock. It is primarily a species of the Chihuahuan Desert, adapted to dry limestone ledges, rock outcrops, and benches. In New Mexico it is infrequent, occurring on limestone or gypsum outcrops at an elevation ranging from 1,219 to 1,829 meters $(4,000-6,000$ feet). Button cacti have not been collected in the Albuquerque area, and have been documented only in the Sierra Lucero range located just west of Belen (P. J. Knight, pers. comm.). Limestone hills within the ACF area are suitable habitat for this species. In addition to the locations in the Sierra Lucero, button cacti have been documented in Eddy, Otero, Lincoln, Chavez, Doña Ana, and Socorro counties, and other parts of Valencia County. In the southern part of New Mexico, this plant is often locally abundant, forming large populations that may extend over hundreds of acres. The primary threat to this species is from cactus collectors who ravage populations once they are located.

5. White-flowered visnagita (Neolloydia intertexta var. dasyacantha) Status: Federal (None); State of New Mexico Endangered (R-E-D Code 1-2-1).

NOTE: This species is in the process of being removed from the list of State of New Mexico Endangered species (Paul J. Knight, pers. comm., April 24, 1994).

Habitat: Chihuahuan Desert Scrub: hot, dry plains with widely scattered shrubs typically of creosotebush, tarbush, mesquite, acacia, and yucca with warm-season grasses, forbs, and cacti in shrub interspaces; widespread throughout Southwest, usually at elevations below 1676.4 meters (5,500 feet). Semidesert Grassland: hot, dry plains of warm-season grasses, such as black grama, dropseed, tobosa, and burrograss; mesquite; and soaptree yucca.

Sensitivity: Low (not seen during survey).

Additional information: The white-flowered visnagita cactus is a rounded columnar medium sized cactus that inhabits grassy limestone slopes at elevations from $1,097.3$ to 1524 meters $(3,600-5,000 \mathrm{ft})$, and within juniper and piñon pine-juniper woodland. It normally has a solitary stem densely covered with interwoven spines. It usually ranges from 2.5 to $18 \mathrm{~cm}(1-7$ inches) tall, but specimens over a foot in height have been recorded (Sullivan and Knight, SAND93-7089, 1994). It normally has 3 or 4 pinkish central spines and about 16 to 25 radial spines per aerole. Each of these spines can range from 0.27 to $1.9 \mathrm{~cm}(0.5-0.75$ inches $)$ long. Its white to pale pink flowers open in April with a small greenish-tan fruit appearing in late spring and often persisting into early summer. The white-flowered visnagita cactus normally occurs on coarse soils or rocky slopes, often on soils derived from rhyolite or volcanic materials. 
Appendix C (Continued)

There are two varieties of this species within New Mexico, but only $N$. $i$. var. dasyacantha is expected to occur in the general Albuquerque area. This variety extends up the Rio Grande drainage as far north as Albuquerque and eastward as far as the Tularosa Basin; however, it is peripheral and scarce in the Albuquerque area. The primary threat to this species is collection by cactus enthusiasts, and to a lesser degree, habitat destruction primarily associated with overgrazing by livestock.

White-flowered visnagita cactus was not observed during the ACF biological survey. However, two individuals were tentatively identified as $N$. intertexta; these individual plants were observed at the junction between the East and West Forks of the Anchor Site Access Road. In New Mexico, this species normally blooms and produces black seeds in July. Both individuals were within 15.2 meters (50 feet) of the existing roadway along the East Fork of the East Anchor Access Road. This is the only location within the 3,840-acre survey area where this species potentially was detected. Positive identification of these individual pincushion cacti should be made during the flowering season (July); therefore, an additional follow-on survey is recommended for a late-June or July time period.

\section{Grama grass cactus (Toumeya papyracantha)}

Status: Federal (C2 Candidate); State of New Mexico (Endangered: R-E-D Code 1-2-2); USFS (Sensitive).

Habitat: Semidesert Grassland: hot, dry plains of warm-season grasses such as black grama, dropseed, tobosa, and burrograss; mesquite; and soaptree yucca. Great Basin Conifer Woodland: Cold-adapted evergreen woodland at intermediate short stature trees of piñon pine and juniper. Plains and Great Basin Grassland: mostly short-grass plains of grama, wheatgrass, threeawn, muhly, galleta, and buffalo grass; dominated by broom snakeweed when continuously grazed by livestock; usually below 2,286 meters $(7,500$ feet) in elevation.

Sensitivity: moderate (not seen during survey, but present in very large numbers in the CCTC area, approximately $4 \mathrm{~km}$ (2.5 miles) away (Sullivan and Knight, SAND93$7089,1994)$.

Additional Information: Grama grass cactus is a small cactus, usually not more than $7.5 \mathrm{~cm}$ (3 inches) tall, occasionally reaching $20 \mathrm{~cm}$ (8 inches) in height. It flowers in April and May with its pale yellow flowers opening in the late afternoon (generally between 2:00 and 6:00 p.m.). It is found throughout central New Mexico ranging from the Ghost Ranch area near Chama, southward to the Alkali Lake Region of Otero County near Dell City, Texas. Its easternmost documented distribution is near Moriarty, but it is likely that it could extend eastward to Santa Rosa, New Mexico. Its western range extends to Holbrook, Arizona. This cactus is somewhat unusual in that its spines are modified, becoming papery. These light-brown to gray papery spines twist and bend much like blades of grama grass. The plants normally grow in 
and among grasses such as blue grama, black grama, and ring muhly where their papery gray-brown spines blend into the adjacent grass, effectively hiding the plant.

Grama grass cactus has been found in a variety of grassland environments. Originally, it was identified in blue grama grasslands. In recent years, it has been found to be abundant in black grama, alkali sacaton, ring muhly, galleta, and dropseed grasslands. It has also been found in gypsophytic plant communities on gypsum deposits as well as in some big sagebrush-grama grass communities. Normally grama grass cactus prefers sandy-gravelly soils between 1,463 and 2,347 meters $(4,800-7,700$ feet) in elevation. It can occur on basalt outcrops with shallow loam soils, on coarse granitic soils, or on silty-clay silts. It is rarely found on sandstone outcrops or limestone soils.

Grama grass cactus populations are somewhat ephemeral, often experiencing great fluctuations in numbers of individual plants. The primary cause for these fluctuations is believed to be infestations of the insect larva of several species of beetles and moths. When population densities at grama grass cactus sites increase, the plants are more vulnerable to such infestations. Some grama grass population sites have been documented to lose as many as 90 percent of the population in one season due to such infestations (Sullivan and Knight, SAND93-7089, 1994). These infestations usually result in populations where only a few scattered remnant plants survive. Seeds from these remnant plants, as well as seeds present in the soil, often result in recovery of the population. Recovering populations often have a few large plants and tiny seedlings present with almost no mid-sized individuals.

Grama grass cactus is threatened by a variety of nonnatural activities. It appears to be highly impacted by cattle grazing. Grazing reduces ground cover, increasing vulnerability to herbivorous mammals such as mule deer, rabbits, hares, and small rodents (i.e., kangaroo rats, woodrats, deer mice). Grazing also results in trampling of the soil and occasionally the plants themselves. Populations under stress from insect infestations that are subsequently subjected to grazing may be extirpated. Grama grass cactus is also highly impacted by habitat destruction associated with urbanization and construction projects. This species also is highly sought after by cactus collectors who can easily collect most of the plants within a population.

Although it occurs sporadically throughout central New Mexico, it has been found at numerous locations in the Albuquerque area, including the northeast heights, and to a lesser degree, on the escarpment on the west side of the Rio Grande Valley. Populations of grama grass cactus are known to occur near Coyote Springs, near the landfill at KAFB (Biggs, 1991), and in large concentrations within the CCTC biological study area of SNL (Sullivan and Knight, SAND93-7089, 1994). 
Appendix C (Concluded)

This species of cactus is extremely difficult to locate during the nonflowering period, yet despite this difficulty, intensive field surveys were conducted in areas potentially capable of supporting grama grass cactus. Surveys were conducted by two biologists spaced 1.8 meters (6 feet) apart. Walking in parallel, each biologists simultaneously and systematically searched all areas potentially capable of supporting grama grass cacti.

Grama grass cactus was not observed during the ACF biological survey. Various other species of cacti that were observed during surveys of grama grass cactus included numerous individual pincushion cacti (Coryphantha vivipara, $\underline{\mathrm{N}}=321$; Coryphantha spp.- - tiny immature individuals), claret-cup cacti (Echinocereus triglochidiatus, $\underline{\mathrm{N}}=60$; Weniger, 1988:52), aggregate cacti (E. coccineus; $\underline{\mathrm{N}}=10$; Weniger, 1988:57), red-goblet cacti ( $E$. polyacanthus, $\underline{N}=15)$, dagger-thorn cholla (Opuntia clavata; $\underline{\mathrm{N}}=240$ patches), and assorted Opuntia (O. imbricata and O. phaeacantha).

\section{Dune unicorn plant (Proboscidea sabulosa)}

Status: Federal (3C); State of New Mexico (Sensitive: R-E-D Code 1-1-2).

Habitat: Semidesert Grassland: hot, dry plains of warm-season grasses such as black grama, dropseed, tobosa, and burrograss. Mesquite and soaptree yucca also occur and may become dominant when grassland is continuously grazed. Chihuahuan Desert Scrub: Hot, dry plains with widely scattered shrubs typically of creosotebush, tarbush, mesquite, acacia, and yucca with warm-season grasses, forbs and cacti in shrub interspaces. Widespread throughout elevations below 1,676 meters (5,500 feet). Sensitivity: Low (none seen during survey).

Additional Information: The dune unicorn plant is a widespread regional endemic, first described in the Trans-Pecos area of Texas. In recent years, its range in the eastern plains has been extended north to Clovis, and in the Rio Grande Valley north to the Sevillita Wildlife Refuge south of Belen. It has never been reported as far north as Albuquerque, but some of the sandier portions of the ACF area could provide suitable habitat for this species, which normally requires deep sandy areas, usually in small dunes. Dune unicorn plant is a herbaceous plant that reaches approximately 1 meter (40 inches) in height. It has large rounded or heart-shaped leaves that are sticky to the touch. It flowers from July through August and produces cream-colored petals that are conspicuously marked with reddish spots or pale blotches on the inside. Lobes of the petals are reddish purple. The most distinctive feature of the plant is its unusual fruit that, when ripe, is woody and has two large pronounced claw-like appendages that curve outward, reaching a length of $15 \mathrm{~cm}$ (6 inches). The dune unicorn plant normally occurs in deep sandy soil between 1,067 and 1,524 meters $(3,500-5,000$ feet) in elevation. It has been reported from the sand dunes along Interstate 25 just south of Belen. There are no known threats to this species. It is uncommon throughout its range and could be locally affected by loss of habitat. 
Appendix D. Currently, endangered and sensitive plant species in New Mexico are classified within various jurisdictional frameworks including the USFWS Endangered Species Act, New Mexico Endangered Plant Species Act, and the USFS Sensitive Species list. Each agency maintains its own list that it considers important for protection or review. Each list has categories distinct from one another. The following is a brief discussion of these categories as they relate to rare species that could occur in the ACF area.

\section{FEDERAL STATUS}

\section{U.S. Fish and Wildlife List:}

The USFWS maintains lists for species that it considers endangered, threatened, proposed endangered, proposed threatened, $\mathrm{C} 1$ (Category 1), C2 (Category 2), 3A, 3B and 3C. Species potentially occurring in the $\mathrm{ACF}$ area are Category $\mathrm{C} 2$ and $3 \mathrm{C}$; legal designations are as follows:

Category 1 Candidate (C1).-Category 1 candidates are species for which there is enough substantial information on biological vulnerability and threats(s) to support proposals to list them as threatened or endangered.

Category 2 Candidate (C2). - Category 2 candidates are species for which additional information is needed to support a proposal to list as threatened or endangered.

Note: These species receive no protection under the Endangered Species Act unless they become listed as threatened or endangered.

Category 3 Species.-Category 3 taxa are those species that were once considered for listing as threatened or endangered, but are not currently receiving such consideration. These taxa include the $\mathbf{3 A}, \mathbf{3 B}$ and $\mathbf{3 C}$ designations.

Category 3A Species.-Category 3A designation comprises taxa for which the USFWS has persuasive evidence of extinction. If rediscovered, however, such taxa might warrant high priority for additions to the Endangered Species List.

Category 3B Species.-Category 3B designation comprises names that on the basis of current taxonomic understanding, usually as represented in published revisions and monograph, do not represent taxa meeting the legal definition of a species as defined in the Endangered Species Act.

Category 3C Species.-Category $3 \mathrm{C}$ designation is applied to those taxa that have proven to be more abundant or widespread than previously believed and have no identifiable threats. 


\section{U.S. Forest Service Sensitive Species List:}

The USFS sensitive rare plant species are those considered sensitive to land use practices within each specific National Forest. Potential impacts to these species on USFS land are regulated by USFS management policies. Collection of these species requires a permit issued by the USFS. Lists are specific to each National Forest.

\section{NEW MEXICO STATUS}

\section{State of New Mexico Plant List:}

The NMFD maintains lists of species that are endangered, sensitive, and/or in review. There is a potential that New Mexico endangered and sensitive plants could occur within the ACF area. These legal designations are:

Sensitive Plants.-Sensitive and rare plant species occurring in New Mexico are those species that are monitored to determine if they should ever be elevated to endangered species status. Species on this list receive no protection under law.

Endangered Plants. - Endangered plant species of New Mexico are those taxa in danger of becoming extinct or in danger of extirpation. The New Mexico Endangered Plant Species Act prohibits collection of these species except in the case of scientific study, and then only under a permit issued by the State of New Mexico. The law also allows for transplantation of plants (under permit) when feasible and prudent. New Mexico uses a coding system to designate listed species. This code (R-E-D) is defined as follows:

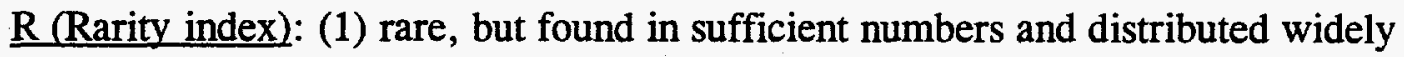
enough that the potential for extinction is low; (2) occurrence confined to several populations or to one extended population; (3) occurrence limited to one or a few highly restricted populations, or present in such small numbers that it is seldom reported.

E (Endangerment index): (1) not endangered, (2) endangered in a portion of its range, (3) endangered throughout its range.

D (Distribution index): (1) more or less widespread outside New Mexico, (2) rare outside New Mexico, (3) endemic to New Mexico.

Example: The Santa Fe milkvetch is designated by New Mexico as Sensitive Code 1-1-3. For this specific code, the first digit is the Rarity index ("occasionally confined to several populations or to an extended population"), the second digit represents Endangered index ("not endangered"), and the third digit is the Distribution index ("endemic to New Mexico"). 
Appendix E. List of animal species observed in the biological study area. Species marked by an * are Threatened, Endangered, Protected, or of Special Concern.

\section{MAMMALS:}

coyote (Canus latrans)

Merriam's kangaroo rat (Dipodomys merriami)

Ord's kangaroo rat (Dipodomys ordii)

banner-tailed kangaroo rat (Dipodomys spectabilis)

Colorado chipmunk (Eutamias quadrivittatus)

bobcat (Felis rufus)

blacktailed jackrabbit (Lepus californicus)

striped skunk (Mephitis mephitis)

white-throated woodrat (Neotoma albigula)

mule deer (Odocoileus hemionus)

northern grasshopper mouse (Onychomys leucogaster)

silky pocket mouse (Perognathus flavus)

rock pocket mouse (Perognathus intermedius)

brush mouse (Peromyscys boylei)

deer mouse (Peromyscus maniculatus)

piñon mouse (Peromyscus truei)

western harvest mouse (Reithrodontomys megalotis)

rock squirrel (Spermophilus variegatus)

western spotted skunk (Spilogale gracilis)

desert cottontail (Sylvilagus auduboni)

black bear (Ursus americanus)

valley pocket gopher (Thomomys bottae)

gray fox (Urocyon cinereoargenteus)

\section{BIRDS:}

sharp-shinned hawk (Accipiter stricture)*

Cooper's hawk (Accipiter cooperi)*

sage sparrow (Amphispiza belli)

black-throated sparrow (Amphispiza bilineata)

scrub jay (Aphelocoma coerulescens)

golden eagle (Aquila chrysaetos)*

Lewis' woodpecker (Asyndesmus lewis)

burrowing owl (Athene cunicularia)*

red-tailed hawk (Buteo jamaicensis)*

Swainson's hawk (Buteo swainsoni)*

lark bunting (Calamospiza melanocorys)

Gambel's quail (Callipepla gambelii)

scaled quail (Callipepla squamata)

whip-poor-will (Caprimulgus vociferus) 
turkey vulture (Cathartes aura)

killdeer (Charadrius vociferus)

green-tailed towhee (Chlorura chlorura)

lark sparrow (Chondestes grammacus)

northern harrier (Circus cyaneus)*

red-shafted flicker (Colaptes auratus)

rock dove (Columba livia)

common raven (Corvus corax)

Chihuahuan raven (Corvus cryptoleucus)

Steller's jay (Cyanocitta stelleri)

warblers (Dendroica spp.)

yellow-rumped warbler (Dendroica petechia)

western flycatcher (Empidonax difficilis)

horned lark (Eremophila alpestris)

American kestrel (Falco sparverius)*

roadrunner (Geococcyx californianus)

piñon jay (Gymnorhinus cyanocephalus)

evening grosbeak (Hesperiphona vespertina)

gray-headed junco (Junco caniceps)

Oregon junco (Junco oreganus)

loggerhead shrike (Lanius ludovicianus)*

acorn woodpecker (Melanerpes formicivorus)

song sparrow (Melospiza melodia)

northern mockingbird (Mimus polyglottos)

Townsend's solitaire (Myadestes townsendi)

sage thrasher (Oreoscoptes montanus)

black-capped chickadee (Parus atricapillus)

mountain chickadee (Parus gambeli)

plain titmouse (Parus inornatus)

house sparrow (Passer domesticus)

common poorwill (Phalaenoptilus nuttallii)

brown (canyon) towhee (Pipilo fuscus)

rufous-sided towhee (Pipilo erythropthalmus)

common bushtit (Psaltriparus minimus)

ruby-crowned kinglet (Regulus calendula)

bank swallow (Riparia riparia)

rock wren (Salpinctes obsoletus)

Say's phoebe (Sayornis saya)

western bluebird (Sialia mexicanus)

red-breasted nuthatch (Sitta canadensis)

pygmy nuthatch (Sitta pygmaea)

Brewer's sparrow (Spizella breweri) 
chipping sparrow (Spizella passerina)

rough-winged swallow (Stelgidopteryx ruficollis)

western meadowlark (Sturnella neglecta)

European starling (Sturnus vulgaris)

violet-green swallow (Tachycineta thalassina)

brown thrasher (Toxostoma rufum)

house wren (Troglodytes aedon)

American robin (Turdus migratorius)

gray vireo (Vireo vicinior)

mourning dove (Zenaida macroura)

white-crowned sparrow (Zonotrichia leucophrys)

\section{REPTILES:}

Chihuahuan spotted whiptail (Cnemidophorus exsanguis)

little striped whiptail (Cnemidophorus inornatus)

desert grassland whiptail (Cnemidophorus uniparens)

western diamondback rattlesnake (Crotalus atrox)

western rattlesnake (Crotalis viridis)

collared lizard (Crotaphytus collaris)

Great Plains skink (Eumeces obsoletus)

lesser earless lizard (Holbrookia maculata)

coachwip (Masticophis flagellum)

gopher snake or bullsnake (Pituophis melanoleucus)

Texas horned lizard (Phrynosoma cornutum)*

short-horned lizard (Phrynosoma douglassi)*

round-tailed horned lizard (Phrynosoma modestum)*

massasauga (Sistrurus catenatus)*

tree lizard (Urosaurus ornatus)

side-blotched lizard (Uta stansburiana) 
This page intentionally left blank. 
Appendix F. List of animal species expected to be in the biological study area. Species marked by an * are Threatened, Endangered, Protected, or of Special Concern.

\section{MAMMALS:}

white-tailed antelope ground squirrel (Ammospermophilus leucurus)

ringtail cat (Bassariscus astutus)

Gunnison's prairie dog (Cynomys gunnisoni)

big brown bat (Eptesicus fuscus)

porcupine (Erethizon dorsatum)

spotted bat (Euderma maculatum)*

greater western mastiff bat (Eumopos perotis californicus)

mountain lion (Felis concolor)

silver-haired bat (Lasionycteris noctivagans)

hoary bat (Lasiurus cinereus)

black-footed ferret (Mustela nigripes)*

myotis bats (Myotis spp.)

occult little brown bat (Myotis lucifugus occultus)*

rock mouse (Peromyscus difficilis)

white-footed mouse (Peromyscus leucopus)

big-eared bat (Plecotus townsendii)

badger (Taxadia taxis)

Mexican free-tailed bat (Tadarida brasiliensis)

gray fox (Urocyon cinereoargenteus)

\section{BIRDS:}

Baird's sparrow (Ammodramus bairdii)*

great horned owl (Bubo virginianus)*

ferruginous hawk (Buteo regalis)*

house finch (Carpodacus mexicanus)

ash-throated flycatcher (Myiarchus cinerascens)

western screech-owl (Otus kennicottii)*

Mexican spotted owl (Strix occidentalis lucida)*

\section{REPTILES:}

plateau striped whiptail (Cnemidophorus velox)

western diamondback rattlesnake (Crotalus atrox)

prairie rattlesnake (Crotalus viridis)

leopard lizard (Crotaphytus wislizenii)

many-lined skink (Eumeces multivirgatus)

striped whipsnake (Masticophis taeniatus)

long-nosed snake (Rhinocheilus lecontei)

eastern fence lizard (Sceloporus undulatus) 
Appendix F (Concluded)

garter snakes (Thamnophis spp.)

\section{AMPHIBIANS:}

tiger salamander (Ambystoma tigrinum)

Great Plains toad (Bufo cognatus)

red-spotted toad (Bufo punctatus)

Woodhouse toad (Bufo woodhousei)

Central Plains spadefoot toad (Scaphiopus bombifrons)

western spadefoot toad (Scaphiopus hammondi) 
Appendix G. Information on State of New Mexico and Federal sensitive species of animals potentially occurring in ACF area. Sources are from the Handbook of Species Endangered in New Mexico, NMDGF 1990; and the USFWS Federal Register, 21 November 1991, Part VIII, Department of the Interior, USFWS, 50 CFR Part 17: Endangered and Threatened Wildlife and Plants; Animal Candidate Review for Listing as Endangered or Threatened Species, Proposed Rule.

\section{Spotted bat (Euderma maculatum)}

Status: Federal (Category 2-Candidate); State of New Mexico (Endangered-Group 2). Habitat: Remote areas, selecting specialized roosting sites with streams, nearby cliffs, or steep hillsides with loose rocks.

Sensitivity: Low (not observed during biological survey).

Additional Information: The spotted bat has been found in New Mexico from the vicinity of the Rio Grande Valley westward, occurring most regularly in the Jemez, San Mateo, and Mogollon Mountains and on Mount Taylor (Fenton, et al., 1983; 1987). These highland localities presumably encompass key habitat characteristics for the spotted bat. In Bernalillo County, the spotted bat is known to occur less regularly, and its regular occurrence is unlikely in recent times (1960 or later), as indicated by unsubstantiated or questionable reports (Handbook of Species Endangered in New Mexico, 1990).

Spotted bats have been reported in a wide variety of habitats, from riparian and piñon pine-juniper woodlands to ponderosa pine and spruce-fir forests (Findley, 1987). In remote areas, bats select specialized roosting sites with streams, nearby cliffs, or steep hillsides with loose rocks. Most recorded observations in New Mexico are in or near forested areas with extensive and rocky cliffs. Spotted bats roost in crevices in cliffs or under loose rocks or boulders, and rocky areas seem to be an important key element of the habitat wherever these bats are found (Easterla, 1965, 1973; Ross, 1961). Spotted bats may summer in forested areas and migrate through lower elevations at other seasons (Hoffmeister, 1986). Lactating females have been taken in New Mexico from late June to mid-July, indicating that young are born in early summer (Findley, 1987). Limiting environmental factors for this species are unknown, although pesticide poisoning is likely a major mortality factor.

There are no records of the spotted bat in the vicinity of ACF, Lurance Canyon, or Sol se Mete Canyon. Because of the lack of key mixed conifer forest habitat and because of the absence of extensive rock ledges and boulders in the immediate ACF area, no effort was made to survey for the presence of this species. Although key geological habitat characteristics for the spotted bat are not evident in the immediate area, these habitat characteristics are somewhat approximated among the escarpments and foothills at the north side of Lurance Canyon and at the head of Lurance Canyon east of the Burn Site. Additionally, some potential cliff habitat occurs along the upper west side (133.6 meters; 7,000 feet) of Sol se Mete Canyon south of ACF. This 
Appendix G (Continued)

species could potentially exist in the ACF area during the non-summer months for purposes of obtaining insect prey as a food source (Hoffmeister, 1986).

2. Greater western mastiff bat (Eumops perotis californicus)

Status: Federal (Category 2-Candidate); State of New Mexico (none).

Habitat: Roosts in buildings, crevices in cliffs, trees, and mine tunnels.

Sensitivity: Low (not seen during survey or reported from ACF area).

\section{Black-footed ferret (Mustela nigripes)}

Status: Federal (Endangered-Category 1); State of New Mexico (none).

Habitat: Grassland vegetation in association with active prairie dog towns.

Sensitivity: Low (not observed during biological survey).

Additional Information: The black-footed ferret is an inhabitant of prairie dog towns.

Ferrets prey on Gunnison's prairie dogs and use their burrows for shelter and denning. In general, black-footed ferrets are secretive and rarely observed. Ferrets are only seen with regularity when females with young are located. This species is primarily nocturnal except for occasional early morning activity of young. Females den in prairie dog burrows and bring young above ground in early July. Young remain in the prairie dog town until they disperse in September or early October. Ferrets are less active in winter and are probably solitary except during the breeding season in early spring (Hillman and Clark, 1980).

Large populations of prairie dogs are found at several highly disturbed locations within KAFB near Gibson Street, South Thunder Range, and western border of the Rocket Sled Track (present survey). This species is a key prey item for black-footed ferrets. Most records of black-footed ferrets for New Mexico are from within the range of Gunnison's prairie dog (Findley, et al., 1975). Bailey (1931) recorded ferrets from the vicinity of San Mateo and Bluewater, and Aldous (1940) collected a ferret at Agua Fria. This species is highly unlikely to occur on the ACF area; it is included here for completeness only.

\section{Occult little brown bat (Myotis lucifugus occultus)}

Status: Federal (Category 2-Candidate); State of New Mexico (none).

Habitat: Montane forest-dweller, roosts in natural caves, mine tunnels, hollow trees, or buildings.

Sensitivity: Low (not observed during biological survey or reported from ACF area).

\section{Northern goshawk (Accipiter gentilis)}

Status: Federal (Category 2 Candidate); State of New Mexico (protected raptor).

Habitat: Coniferous forest, spruce forest, high elevations in mountains; wintering along willow-fringed streams in desert valleys, may move down into grassland and desert landscapes, brushy draws or sparsely treed coulees, and river bottoms; nesting 
associated with coniferous forest, seldom nests below $3,500-4,000$ meters $(11,483$ 3,123 feet), usually associated with lodgepole, piñon pine, or yellow pine.

Sensitivity: Low (not observed during biological survey).

Additional Information: In North America, the species is strongly associated with coniferous forest. It breeds continent-wide in the northern spruce forest and south at increasing elevations in the mountains, reaching into subtropical latitudes in the west, in associations with high-elevation coniferous forest of the cordillera. The race A. $g$. apache is the Mexico-Arizona-New Mexico highland form. This subspecies is a resident that may migrate downslope to lower elevations, but does not normally cross latitudes. In fact, in the western cordillera region, extending from Alaska to Mexico, the migration pattern of the goshawk, if it exists at all, is difficult to trace. Most goshawks winter along willow-fringed streams in desert valleys of Utah, New Mexico, or California and do not necessarily come from any remote northern forest. The forests that they come from may be only a few kilometers away, but from 3,000 to 4,000 meters $(9,843-13,123$ feet) in elevation above the wintering areas. Further, there is additional confusion about migratory patterns of goshawks because there is no year, or any time of year, when goshawks, both adult and first-year birds, are not present in northern forests.

Close association of goshawks with coniferous forests is a characteristic modified only in winter. In the west, some birds may move down into grassland and desert landscapes where they tend to frequent brushy draws or sparsely treed coulees and river bottoms. When nesting, this bird is primarily associated with coniferous forest habitat, and even nonbreeding birds appear to return to conifer-darkened woods by April or May. The goshawk inhabits and reproduces in every type and subtype of coniferous woods that occurs in North America.

In the Southwest, it nests at high elevations, often in somewhat insular populations, or even isolated pairs. In Mexico and Arizona it seldom nests below 3,000 to 4,000 meters $(9,843-13,123$ feet), and is usually associated with lodgepole, piñon pine, or yellow pine. In New Mexico, this species uses primarily moderate to high canopied mature coniferous forests with minimal understory. Goshawks are forest habitat generalists that use a wide variety of forest ages, structural conditions, and successional stages. Nest sites are found in forest stands with a high density of large trees and canopy closure. This species preys on large- to medium-sized birds and mammals that it captures on the ground, in trees, or in the air (grouse, snowshoe hare, red squirrel, chipmunks, woodpeckers, passerine birds, and Steller's jay). Food requirements of a single goshawk total about one or two medium-to-large prey per day.

\section{Baird's sparrow (Ammodramus bairdii)}

Status: Federal (Category 2-Candidate); State of New Mexico (Endangered-Group 2). 
Appendix G (Continued)

Habitat: Desert grasslands, prairies, mountain meadows.

Sensitivity: Low (not observed during biological survey).

Additional Information: Sightings of Baird's sparrows normally occur during migration in the eastern plains and southern lowlands, mainly in autumn-with vagrants elsewhere. It nests in lightly grazed pastures; undisturbed prairie, moist meadows, and dry rangeland. The only reliable winter record is from the Roswell area (Handbook of Species Endangered in New Mexico, 1990). Recent records are mainly in the Animas Valley (Hidalgo Co.), which is assumed to represent an area of key critical habitat for the species. Other reliable reports in areas where the species may occur are from Dry Cimarron Valley (Union Co.) and near Nutt (Luna Co.).

Baird's sparrow is a retiring sparrow found in shrubby short-grass habitats. It is usually flushed before it is observed, only to fly a short distance and drop down out of sight in grassland vegetation (Handbook of Species Endangered in New Mexico, 1990). In New Mexico, this species has been found in a variety of habitats, ranging from desert grasslands in the south to prairies in the northeast and mountain meadows in the San Juan and Sangre de Cristo Mountains to an elevation of 3,600 meters (11,811 feet) (Handbook of Species Endangered in New Mexico, 1990:F-580). Migrants arrive as early as the first week of August. By November most sparrows appear to have moved out of New Mexico.

In Bernalillo County, Baird's sparrow is known to occur less regularly, and its regular occurrence is unlikely in recent times (1960 or later), as indicated by unsubstantiated or questionable reports (Handbook of Species Endangered in New Mexico, 1990). There are no records of Baird's sparrow in the immediate vicinity of ACF.

\section{Golden eagle (Aquila chrysaetos)}

Status: Federal (Endangered species); State of New Mexico (protected raptor).

Habitat: Open tilted landscapes, desert-grassland-juniper habitat, montane woodland and

forests, deeply cut by streams and canyons, and rising to open or sparsely treed mountain slopes and rock crags-all elevations; hunts small mammals (ground squirrels, prairie dogs, rabbits, hares); high cliff ledges or faces are favored substrates for nest construction, also nests in trees associated with precipitous, rock cliff terrain.

Sensitivity: Low (1 individual seen just north of ACF boundary).

Additional Information: The golden eagle inhabits open tilted landscapes, desertgrassland-juniper habitat, montane woodland and forests, deeply cut by streams and canyons, and rising to open or sparsely treed mountain slopes and rock crags. Range of this species covers all elevations in North America. Golden eagles hunt primarily small mammals, including ground squirrels, prairie dogs, rabbits, and hares. High cliff ledges or faces are favored substrates for nest construction, but in areas where 
this type of habitat is unavailable they will also construct nests in trees associated with precipitous, rock cliff terrain.

One golden eagle was seen during the ACF biological survey. It was observed in grassland-juniper habitat along the north side of Lurance Canyon Road, $1.6 \mathrm{~km}$ (1 mile) west of the Explosive Assembly Building and 30.5 meters (100 feet) north of Lurance Canyon Road.

\section{Burrowing owl (Athene cunicularia)}

Status: Federal (none); State of New Mexico (protected raptor).

Habitat: Bare ground, open desert, grassland-juniper habitat, nests in abandoned rodent burrows.

Sensitivity: Low (not observed during biological survey).

Additional Information: The burrowing owl inhabits bare ground, open desert, and grassland-juniper habitat and nests in abandoned rodent burrows. They modify these burrows by digging and scraping with the beak, wings, and feet. However, burrowing owls were observed on the nearby CCTC site in association with disturbed embankments at the north end of the Rocket Sled Track ( 2 birds), along the fence line at the northwest border of the Rocket Sled Track (6 birds), and the South Thunder Range near the helicopter landing pad (5 birds) (Sullivan and Knight, SAND93-7089, 1994). One burrow was observed at the west end of the second most northern radar tracking pad directly west of the Rocket Sled Track, but no birds were in it.

9. Great horned owl (Bubo virginianus)

Status: Federal (none); State of New Mexico (protected raptor).

Habitat: Plains, open spaces, woodlands, riparian areas, forests.

Sensitivity: Low (not observed during biological survey).

Additional Information: The great horned owl is widely distributed throughout North and

South America in a variety of habitats. In the Southwest, it is a common inhabitant of relatively arid grassland regions, including plains, open spaces, deserts, woodlands, and riparian areas. Prey consists of small- to medium-sized mammals that it hunts primarily from perches such as fence posts, low trees, buildings, or from other elevated vantage points on the ground. Although the great horned owl was not observed during the ACF biological survey, it was observed by CCTC personnel roosting in man-made structures associated with the Drop Tower and Water Impact facilities (Sullivan and Knight, SAND93-7089, 1994).

10. Ferruginous hawk (Buteo regalis)

Status: Federal (Category 2); State of New Mexico (protected raptor).

Habitat: Plains, open spaces, deserts, woodlands, riparian areas.

Sensitivity: Low (not observed during biological survey). 
Additional Information: The ferruginous hawk inhabits grassland and unbroken terrain in the Great Plains and arid intermountain regions of western Canada and the United States. This species uses a variety of nesting sites, including ground nests on low hillsides, cutbanks, and buttes; trees in open country; and drainage areas and powerline structures. Specific habitat includes plains and open spaces, deserts, woodlands, and riparian areas. The diet of the ferruginous hawk includes primarily rabbits, hares, and ground squirrels. One ferruginous hawk was observed over the nearby CCTC South Thunder Range (Sullivan and Knight, SAND93-7089, 1994).

\section{Swainson's hawk (Buteo swainsoni)}

Status: Federal (none); State of New Mexico (protected raptor).

Habitat: Plains, open spaces, deserts, woodlands, riparian areas.

Sensitivity: Low (not observed during biological survey).

Additional Information: The Swainson's hawk (Buteo swainsoni) is neither a Federal nor

State of New Mexico Endangered, or Sensitive species; however, all raptors are fully protected by the State of New Mexico. This species is a common inhabitant of the Great Plains and relatively arid areas of grassland in the West, including plains, open spaces, deserts, woodlands, and riparian areas. It builds flimsy nests in shrubs and trees along wetlands and drainages, and in windbreaks in fields around farmsteads. Prey consists of small mammals, birds, large insects, and reptiles that it hunts primarily from perches such as fence posts, low trees, or from elevated vantage points on the ground. This species moves in response to locally high concentrations of prey more than most other species of raptors. One adult Swainson's hawk (light-morph) was observed in grassland habitat at the extreme southwest border of the South Thunder Range, CCTC biological study area (Sullivan and Knight, SAND93-7089, 1994).

\section{Southwestern willow flycatcher (Empidonax traillii extimus)}

Status: Federal (Category 1-Candidate); State of New Mexico (Endangered-Group 2). Habitat: Riparian, piñon pine-juniper, ponderosa pine, spruce-fir forest.

Sensitivity: Low (not observed during biological survey).

Additional Information: The southwestern willow flycatcher is a rather small flycatcher and has a breeding range that extends from southern California and Baja California eastward through Arizona, southern Utah, central New Mexico, and Trans-Pecos Texas. In New Mexico, the species occurs statewide during the spring and autumn migration (Handbook of Species Endangered in New Mexico, 1990). This species breeds in the Chama, Rio Grande, Zuni, San Francisco, Gila, and possibly the Hondo River Basins, and in the San Juan and western Sangre de Cristo Mountains. Areas of key breeding habitat encompass Zuni (McKinley Co.), Corrales (Sandoval Co.), upper Elephant Butte Lake (Sierra Co.), Glenwood-Pleasanton (Catron Co.), and Cliff-Rock (Grant Co.). This species is known or is highly likely to occur in Bernalillo County (Handbook of Species Endangered in New Mexico, 1990). 
Appendix G (Continued)

The willow flycatcher is generally restricted to riparian woodlands during the breeding season (Hubbard, 1987). Key habitats are typically dominated by cottonwoods, often in association with an understory of small trees or tall shrubs, and surface water. The range in elevation for breeding willow flycatchers in New Mexico is from 1,121 to 2,696 meters $(3,678-8,846$ feet) with occurrences above $2,133.6$ meters $(7,000$ feet) confined to the northern highlands. Breeding birds generally spend much of their time beneath the overstory canopy in willows or other plants including salt-cedar in the Rio Grande Valley. Willow flycatchers are present in New Mexico through late July; therefore, the biological survey of the ACF area was timely for this species.

Breeding populations of this species in many areas are presumed to have been reduced because of loss of riparian habitat (Unitt, 1987)-a situation that led to the listing of this subspecies as endangered. The breeding population in New Mexico is estimated at 100 pairs, and numbers of birds have declined in the lower and perhaps middle Rio Grande Valley (Handbook of Species Endangered in New Mexico, 1990). Protection and restoration of natural riparian habitats are essential steps in the conservation of breeding willow flycatchers in New Mexico, with diagnostic elements being an overstory of tall cottonwood trees and understory of smaller trees and large shrubs located nearby areas of surface water.

\section{American peregrine falcon (Falco peregrinus anatum)}

Status: Federal (Endangered-Category 1); State of New Mexico (EndangeredGroup 1).

Habitat: Areas of steep rocky cliffs in close proximity to water; preferred habitat contains dense bird populations in conjunction with large gulfs of air such as occurs in canyons.

Sensitivity: Low (not observed during biological survey).

Additional Information: Historically, the peregrine falcon bred throughout much of North America. The subspecies $F$. $p$. anatum breeds south of the arctic tundra region of North America, southward to Mexico. In New Mexico, this subspecies breeds locally in mountainous areas, and it occurs in migration and winter essentially statewide, but primarily east of the eastern plains (Handbook of Species Endangered in New Mexico, 1990). In New Mexico, breeding territories of the peregrine falcon center on wooded and forested cliffs that provide strong up-drafts of air in which the species can forage. Jays, woodpeckers, swifts, mourning doves, and pigeons are commonly taken as prey by peregrine falcons in New Mexico. A decline in the population of peregrine falcons in New Mexico is associated with ingestion of pesticides (Handbook of Species Endangered in New Mexico, 1990). This decline, however, appears to have leveled off by the late 1970's. At present, the small breeding population appears to be stable in New Mexico (Handbook of Species Endangered in New Mexico, 1990). 
The peregrine falcon was not observed in the biological study area at any time during the biological survey from early October to November. However, it is known to occur in Bernalillo County and all of the surrounding counties. This species, therefore, could potentially exist within the biological study area. Peregrine falcons normally nest on steep cliffs in wooded or forested areas. This general type of habitat exists among the escarpments and foothills along the north side of Lurance Canyon and at the head of Lurance Canyon east of the Burn Site. Additionally, rather extensive cliff habitat occurs along the upper west side (2,133.6 meters; 7,000 feet) of Sol se Mete Canyon south of ACF. Many of the smaller species of birds that are typical prey-species for the peregrine falcon also occur and are abundant in the biological study area. Although the region associated with Lurance Canyon provides "marginal" nesting habitat, the grassland-juniper habitat in Lurance Canyon and the predominantly grassland and grassland-sagebrush habitat within ACF could provide some foraging habitat for the species.

\section{Mexican spotted owl (Strix occidentalis lucida)}

Status: Federal (Proposed Threatened); State of New Mexico (Endangered-Group 2). Habitat: Caves, cliff ledges, witches'-broom, stick nests of other species, old growth forest with steep canyons, mixed conifer forest preferred, but found in piñon pine-juniper, pine-oak, ponderosa pine.

Sensitivity: Low (not observed during biological survey).

Additional Information: The Mexican spotted owl has been recorded in all New Mexico National Forests at elevations from 1,127.8 to 3,048 meters $(3,700-10,000$ feet). Habitat consists of caves, cliff ledges, witches'-broom, and stick nests of other avian species in mature and old growth forest associated with steep canyons. The preferred vegetation type is mixed conifer; however, they can be found in piñon pine-juniper woodland, and pine-oak and ponderosa pine forests.

Although key geological habitat characteristics for the Mexican spotted owl are not evident in the immediate area, these habitat characteristics are somewhat approximated among the escarpments and foothills at the north side of Lurance Canyon, at the head of Lurance Canyon east of the Burn Site, along upper elevations of Sol se Mete Spring Canyon, and in the small area of Ponderosa pine-piñon pine-oak woodland along the upper elevations of the East Anchor Access Road.

A special survey was completed by a qualified spotted owl raptor expert, Roger Skaggs. Mr. Skaggs conducted a visual survey of all areas within the ACF sphere of influence. His conclusions were that the surveyed area is not a suitable habitat for the spotted owl, and that the use of calling protocols (USFS standards) would be a waste of time and money. The habitat described by Mr. Skaggs at ACF closely resembles habitat he surveyed in the Lincoln National Forest. For the latter area, considerable 
efforts were made using USFS calling protocols, and no evidence was produced of spotted owl occupancy. His report is attached at Appendix I.

\section{Massasauga (Sistrurus catenatus)}

Status: Federal (none); State of New Mexico (recommended for listing as Endangered, 13 April 1990).

Habitat: Grassland-juniper habitat, low areas of rank vegetation growth.

Sensitivity: Low (not observed during biological survey).

Additional Information: In the eastern United States the massasauga or "swamp rattler" is an inhabitant of river bottoms, wet prairies, swamps, and bogs, but also enters dry woodland. In the west, it occurs in desert grassland, particularly in low areas of rank growth typical of the Rio Grande Valley, and in low plains of mesquite, juniper, and grassland that have been degraded in some areas by overgrazing and associated abusive land uses. Although this species was not observed during the ACF survey, it is common in similar grassland habitat throughout the nearby CCTC area (Sullivan and Knight, SAND93-7089, 1994). 
This page intentionally left blank. 
Appendix H. Currently, endangered and sensitive animal species in New Mexico are classified within various jurisdictional frameworks including the USFWS Endangered Species Act (Public Law 100-478), NMDGF endangered species program (1991, Handbook of Species Endangered in New Mexico; New Mexico Statutes 1978, Annotated, Pamphlet 33, Chapter 17-214), USFS Sensitive Species list, and Migratory Bird Treaty Act (16 USC 703711). Each agency maintains its own list of species that it considers important for protection or review. Each list has categories distinct from one another. The following is a brief discussion of these categories as they relate to rare species that could occur in the ACF area.

\section{FEDERAL STATUS}

U.S. Fish and Wildlife List:

The USFWS maintains lists for species that it considers endangered, threatened, proposed endangered, proposed threatened, C1 (Category 1), C2 (Category 2), 3A, 3B and 3C. Species potentially Category $\mathrm{C} 2$ and $3 \mathrm{C}$ exist within the $\mathrm{ACF}$ area; legal designations are as follows:

Category 1 Candidate (C1).-Category 1 candidates are species for which there is enough substantial information on biological vulnerability and threats to support proposals to list them as threatened or endangered.

Category 2 Candidate (C2). - Category 2 candidates are species for which additional information is needed to support a proposal to list as threatened or endangered.

Note: These species receive no protection under the Endangered Species Act unless they become listed as threatened or endangered.

Category 3 Species.-Category 3 taxa are those species that were once considered for listing as threatened or endangered, but are not currently receiving such consideration. These taxa include the $\mathbf{3 A}, \mathbf{3 B}$ and $\mathbf{3 C}$ designations.

Category 3A Species.-Category 3A designation comprises taxa for which the USFWS has persuasive evidence of extinction. If rediscovered, however, such taxa might warrant high priority for additions to the Endangered Species List.

Category 3B Species. - Category 3B designation comprises names that on the basis of current taxonomic understanding, usually as represented in published revisions and monograph, do not represent taxa meeting the legal definition of a species as defined in the Endangered Species Act.

Category $3 \mathrm{C}$ Species.-Category $\mathbf{3 C}$ designation is applied to those taxa that have proven to be more abundant or widespread than previously believed and that have no identifiable threats. 
Appendix $\mathbf{H}$ (Concluded)

Protected. - The golden eagle is a fully Federally protected species under Public Law 93-205 and 16 USC 668a, which designated the bald eagle and the golden eagle as Endangered species.

\section{STATE OF NEW MEXICO ENDANGERED}

Group 1.-Taxa whose prospects of survival or recruitment within the State of New Mexico are in jeopardy.

Group 2.-Taxa whose prospects of survival or recruitment within the State of New Mexico are likely to become jeopardized in the foreseeable future. 
Appendix I. Summary report from Roger Skaggs, spotted owl biologist.

26 September 1993

\section{REPORT FOR:}

Roy Cunniff

Physical Sciences Laboratory

New Mexico State University

Las Cruces, NM

\section{FROM:}

Roger W. Skaggs

PO Box 214

Glenwood, NM 88039

\section{SUBJECT:}

Results of field analysis of the Sandia National Laboratories Aerial Cable Facility (ACF) to determine habitat potential for Mexican Spotted Owls.

\section{BACKGROUND:}

The Mexican Spotted Owl (Strix occidentalis lucida) presently is listed as Threatened by the US Fish and Wildlife Service.

Mexican Spotted Owls occur in most major mountain ranges in New Mexico, including the Manzano and Sandia Mountains (Hubbard, 1978; Johnson and Johnson, 1985). In southern New Mexico, this species primarily is found in mixed-conifer forests from 1,981 to 2,743 meters $(6,500-9,000$ feet) where multi-layered forest canopies provide daytime roosts (Skaggs, 1988; Skaggs and Raitt, 1988). Mexican Spotted Owls may also breed at lower elevations in areas of piñon-juniper woodlands if these landscapes are cut by very steep or cliff-lined canyon bottoms where the owls can find shaded roost and nest sites. Such habitat normally is provided by the cliffs or well developed riparian forests in the canyon bottom.

\section{FIELD RECONNAISSANCE:}

I visited the Sol se Mete ACF on 10 September 1993 to assess its potential as breeding habitat for Mexican Spotted Owls. I visually surveyed Sol se Mete Canyon from its confluence with Coyote Canyon to a point $0.5 \mathrm{~km}$ up-canyon above Sol se Mete Spring (Figure 16). I also examined habitats in the vicinity of the Burn Site further up Lurance Canyon to the east. The habitats I saw were open piñon-juniper woodlands with dry canyon bottoms (see habitat descriptions in Sullivan, 1993). 
Appendix I (Continued)

\section{CONCLUSIONS:}

The open woodland slope and canyon-bottom habitats in Sol se Mete Canyon do not provide the shaded roost and nesting sites typical of habitats occupied by breeding Spotted Owls elsewhere in this region. The habitat at Sol se Mete Canyon is typical of other areas in Lincoln National Forest at which I used a variety of USFS-approved calling protocols to no avail. It is my opinion that a full-scale protocol survey is not warranted for Sol se Mete Canyon and the ACF area.

\section{LITERATURE CITED:}

Hubbard, J. P. 1978. Revised Checklist of the Birds of New Mexico. New Mexico Ornithological Society Pub. No. 6.

Johnson, J. and T. Johnson. 1985. The Status of the Spotted Owl in Northern New Mexico. New Mexico Department of Game and Fish. Contract \# 516.6-73-03. Santa Fe, NM 39pp.

Skaggs, R. W. 1988. The Status of the Spotted Owl in Southern New Mexico: 1901-1987. New Mexico Department of Game and Fish. Contract \# 519-75-02. 12pp.

Skaggs, R. W. and R.J. Raitt. 1988. A Spotted Owl Inventory on the Lincoln National Forest Sacramento Division. New Mexico Department of Game and Fish. Contract \#5516.6-76-17. 12pp.

Sullivan, R. M. 1993. Biological Investigations of the Sandia National Laboratories Sol se Mete Aerial Cable Facility. Contractor Report SAND93-7093. 


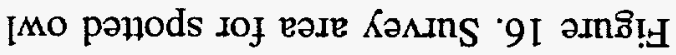

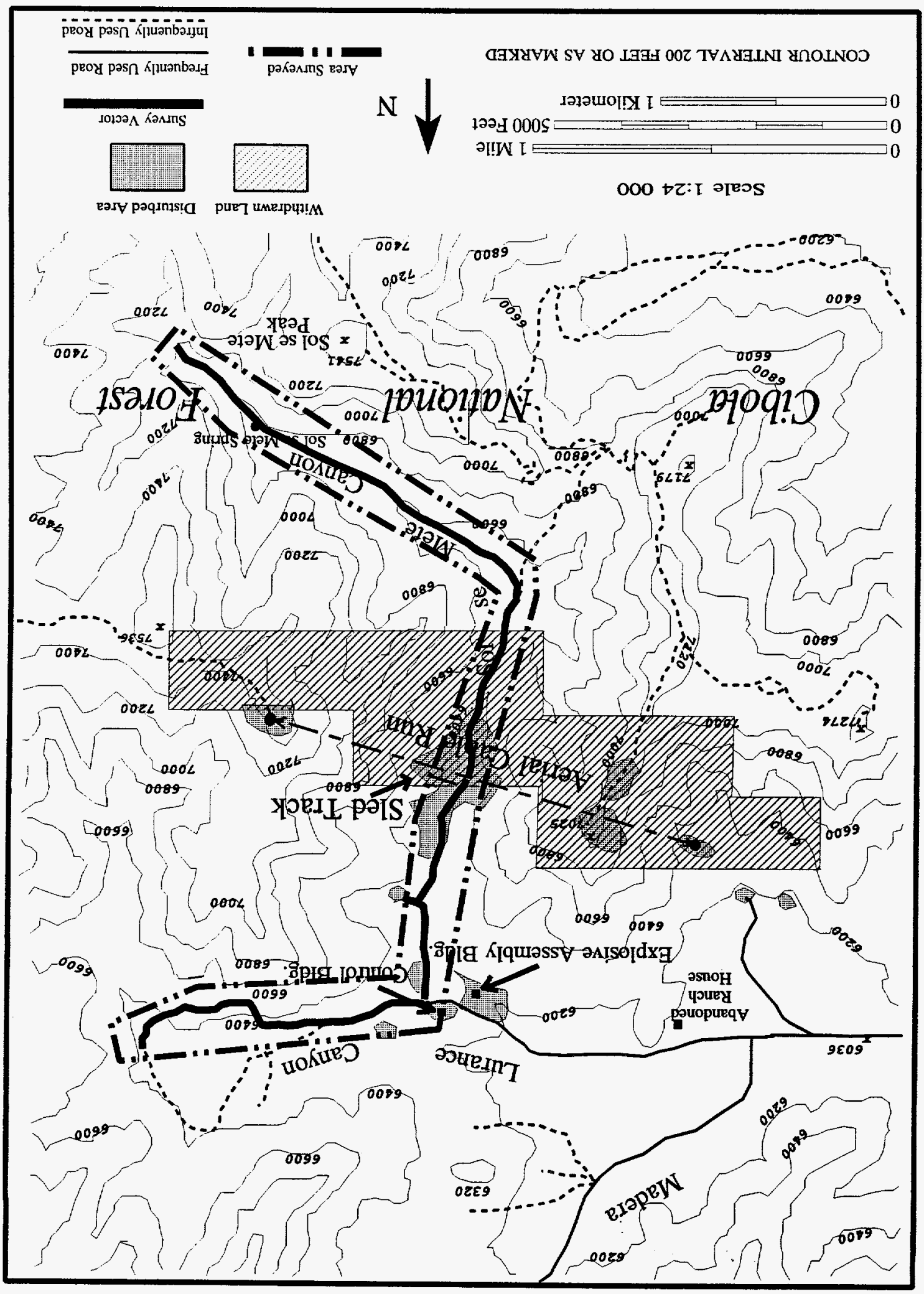

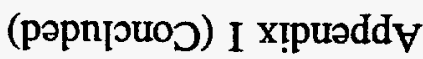


This page intentionally left blank. 